\title{
Expedition 340 summary ${ }^{1}$
}

\author{
Expedition 340 Scientists $^{2}$
}

\section{Chapter contents}

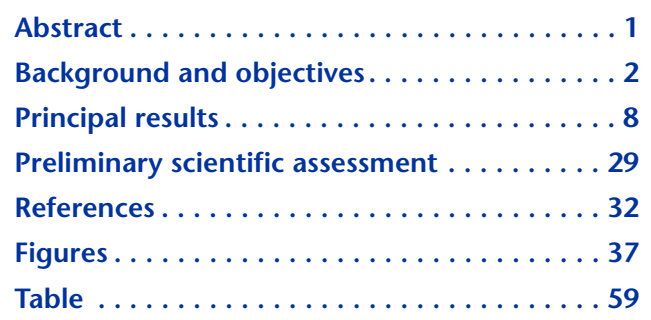

${ }^{1}$ Expedition 340 Scientists, 2013. Expedition 340 summary. In Le Friant, A., Ishizuka, O., Stroncik, N.A., and the Expedition 340 Scientists, Proc. IODP, 340: Tokyo (Integrated Ocean Drilling Program Management International, Inc.). doi:10.2204/iodp.proc.340.101.2013

'Expedition 340 Scientists' addresses.

\section{Abstract}

The Lesser Antilles Volcanism and Landslides project aims to elucidate the constructive and destructive processes of island arc volcanoes. The data set collected includes the first ever drilling of volcanic island landslides and cores providing a long-term record of volcanic eruption cycles and magmatic evolution. Processes occurring along these arcs are among the most fundamental on Earth. Styles of magmatism and eruptive activity are diverse in this geological setting not only between different arcs but also between the different islands that make up an arc. Because of the association of volcanic activity in island arcs with potentially very damaging geohazards (explosive eruptions and tsunamis), it is imperative to investigate and thus better understand the evolution of these volcanoes and the histories of their related landslides.

Knowledge of island arc volcanism has previously been limited mainly to the subaerial geological record. Combining this record with information from related submarine deposits will provide a more complete picture of volcanic activity in this geological setting. The Lesser Antilles arc lends itself well to achieving this combined record, offering a diverse range of magmatic and eruptive styles across a relatively small geographic area. In addition, the frequency of events that result in the deposition of mass transport deposits is high, with the style of processes varying along the arc.

Integrated Ocean Drilling Program Expedition 340 focused on nine strategic drill sites around Montserrat and Martinique, as they are representative of the entire eruptive activity across the Lesser Antilles arc. We recovered 434 cores containing $2384 \mathrm{~m}$ of seafloor sediment samples. This expedition has shown that large mass-wasting deposits around volcanic islands can comprise large volumes of seafloor sediment, which has significant implications for tsunami generation. Initial emplacement of volcanic material on the seafloor can trigger even larger secondary failures of the seafloor sediment. Offshore Montserrat, Site U1395 sampled a $7 \mathrm{~m}$ thick interval of stacked turbidites associated with the largest recent landslide, whereas Site U1396 provides a 4.5 m.y. record of eruptions on the island. Offshore Martinique, Sites U1399 and U1400 penetrated chaotic deposits comprising only tilted or more strongly deformed bedded seafloor sediments. Site U1397 provides a 400 k.y. record of eruptions of Martinique and Dominica.

Data and samples acquired during this expedition are stored at the Gulf Coast Repository at Texas A\&M University (USA) and will be carefully screened to further investigate magmatic evolution 
and eruptive activity along the Lesser Antilles arc. In addition, we hope to reach a better understanding of the mechanisms involved in both the transport and deposition of volcanic debris avalanche deposits and to assess the potential for volcanic hazards associated with these avalanches.

\section{Background and objectives}

\section{Background}

\section{The Lesser Antilles arc}

The Lesser Antilles arc results from the subduction of the Atlantic oceanic plate beneath the Caribbean plate (Fig. F1). Recent plate convergence rates are relatively slow (2-4 cm/y; Feuillet et al., 2002), and magma productivity has been low relative to other arcs; estimates vary between 3 and $5 \mathrm{~km}^{3} / \mathrm{m} . \mathrm{y} . / \mathrm{km}$ (Sigurdsson et al., 1980; Wadge, 1984; MacDonald et al., 2000). Volcanic activity along the arc started at $\sim 40$ Ma (Martin-Kaye, 1969; Bouysse et al., 1990).

North of Dominica, the arc is divided into two island chains and is built on an extinct ocean island arc from the Cretaceous period (Bouysse and Guennoc, 1983; Wadge, 1986). The eastern chain corresponds to an older extinct arc, the volcanic basement of which is now covered by a thick carbonate platform. The western chain is the site of active volcanism since $20 \mathrm{Ma}$ (Briden et al., 1979). South of Dominica, the older and more recent arcs merge, forming one chain of islands bordered to the west by the $2900 \mathrm{~m}$ deep backarc Grenada Basin. The Grenada Basin is a major depocenter for large debris avalanche deposits (Fig. F1), volcanogenic turbidites, large pyroclastic flow deposits, and hemipelagic sediment (Sigurdsson et al., 1980; Deplus et al., 2001; Picard et al., 2006; Boudon et al., 2007). Rates of background hemipelagic sedimentation vary from $1-2 \mathrm{~cm} / \mathrm{k}$.y. west of the northern islands to $10-20 \mathrm{~cm} / \mathrm{k} . \mathrm{y}$. in the Grenada Basin to the south (Reid et al., 1996; Duchoiselle, 2003). In the absence of any deep drilling projects in the region, knowledge of the volcanic history of the arc, based on the marine record, is limited to the last 300 k.y. (in most places $\ll 100$ k.y.).

\section{Eruptive history along the Lesser Antilles arc}

The Volcanic Hazard Atlas of the Lesser Antilles (Lindsay et al., 2005a) provides a good synthesis of available information on the volcanoes of the arc. One characteristic of Lesser Antilles arc volcanism is that many of the volcanic centers overlap in both space and time (Lindsay et al., 2005a). Volcanic activity is observed to migrate from north to south (e.g., Montserrat; Harford et al., 2002) or south to north (e.g., Martinique; Boudon et al., 2005) or to cluster in contemporaneous centers (Dominica; Lindsay et al., $2005 b$ ). In each case, discrete volcanic centers develop and appear to remain active for $5 \times 10^{5}$ to $5 \times 10^{6} \mathrm{y}$, although these inferred timescales are not well constrained. The onset of volcanic activity is generally unknown because the earliest products are not easily accessible through standard geological investigations.

It is often difficult to constrain the eruptive history of a volcano beyond the start of written historical records or beyond ages that are greater than those of well-preserved subaerial tephra deposits. Deciphering a complete eruption record from onshore geology alone can be problematic because of burial by subsequent deposits, growth of dense vegetation obscuring deposits, erosion, and remobilization of deposits by flank-collapse events. Marine sediment typically preserves a much more complete record of volcanic activity.

Over the past decade several studies of the magmatic history of a number of Lesser Antilles volcanoes have been carried out based on tephra deposits retrieved from piston coring of marine sediment during the 2002 Caraval cruise (Boudon et al., 2004, 2008; Duchoiselle, 2003; Vennat, 2004; Le Friant et al., 2008; Machault, 2008). Correlations have been found between tephra sampled in a piston core off one island and volcanic deposits from volcanoes on different islands. In the case of the Montagne Pelée Volcano on Martinique, piston cores ( $7 \mathrm{~m}$ in length) extended the eruptive record to $>25 \mathrm{ka}$. In addition, 25 eruptive events have been identified within marine deposits between 5 and $15 \mathrm{ka}$ compared to only 10 magmatic events previously recognized onshore for the Montagne Pelée Volcano. For the Soufrière Hills Volcano (Montserrat), the record has been extended to $\sim 250 \mathrm{ka}$ in a $5.8 \mathrm{~m}$ piston core in an area of low sedimentation rate. The marine core also recorded several explosive Plinian eruptions that were not identified on land (Le Friant et al., 2008). Each volcanic island has a distinctive mineralogy and geochemistry (Sigurdsson et al., 1980; Lindsay et al., 2005a) owing to changes in magma types along the arc. Distinguishing the sources for tephra layers in cores is therefore straightforward.

\section{Long-term magmatic evolution of the volcanic arc}

Volcanism varies markedly along the Lesser Antilles arc (MacDonald et al., 2000; Lindsay et al., 2005a). Generally, magma becomes enriched in incompatible elements (notably K) and radiogenic isotopes southward along the arc. This enrichment may be related to the increasing influence of subducted Orinoco sediment from the South American continent that is supplied into the forearc region from the 
south (MacDonald et al., 2000). In addition, it may be a consequence of variations in the subduction rate and subduction geometry normal to the arc. In the south, St. Vincent, Grenada, and the Grenadine Islands are dominated by basaltic to basaltic andesitic magma. Soufrière Volcano on St. Vincent and the submarine Kick'em Jenny Volcano are the two historically active centers in this area. In the central Lesser Antilles, St. Lucia, Dominica, and Martinique are large islands dominated by silicic magma with subsidiary mafic magma. Relatively high rates of volcanism can be inferred from the regional inventory of marine tephra layers from these islands (Sigurdsson et al., 1980), as well as the size of the volcanic centers. Duchoiselle (2003) and Boudon et al., (2004) estimated a recurrence rate of 2.6 magmatic eruptions/k.y. for Montagne Pelée Volcano on Martinique. Volcanism on all the central islands has resulted in several large Plinianstyle explosive eruptions with associated ignimbrites in the recent geological past. In the north, the volcanoes of Soufrière Hills on Montserrat and Soufrière on Guadeloupe have produced dominantly andesitic magma, whereas Nevis, St. Kitts, St. Eustatius, and Saba have erupted substantial volumes of basaltic and andesitic magma. However, their magma production rates and eruption frequency are comparatively low (e.g., 0.5 magmatic eruptions/k.y., Soufrière Volcano on Guadeloupe; Komorowski et al., 2005). Alternating periods of longer intervals of constant magma compositions with shorter intervals of varying magmatic compositions are typically observed on timescales of $\sim 1 \mathrm{~m} . \mathrm{y}$. across this transition zone.

Much of the compositional variability observed in single volcanoes on the arc can be related to magma formation and evolutionary processes within the crust. Annen et al. $(2006,2008)$ provide a conceptual framework for understanding the dynamics of magma generation, magma differentiation, and transport. Magma flux rates are considered to be the major control on the formation of shallow magma chambers containing eruptible magma and of their compositions. Understanding the igneous processes of volcanic arcs and the subduction zone engine is fundamental because they provide a viable mechanism to generate continental crust and are key components of globalscale geochemical cycling.

\section{Flank-collapse events}

Volcano flank collapses are increasingly recognized as a normal process in the destruction of volcanic edifices (Ida and Voight, 1995; McGuire, 1996; Voight, 2000). They play a significant role not only in the evolution of volcanic edifices but also in the dynamics of subsequent eruptions. In addition, these collapses are a significant volcanic hazard. The recognition of flankcollapse events is based on mapping debris avalanche deposits that can be traced to a generally horseshoeshaped collapse scar on the volcano (Voight, 1981). The most voluminous events (volumes from tens to hundreds or even thousands of cubic kilometers) have been recognized off oceanic islands such as Hawaii (Lipman et al., 1988; Moore et al., 1989) and La Réunion (Labazuy, 1996; Oehler et al., 2004, 2008), as well as on the Canary archipelago (Holcomb and Searle, 1991; Watts and Masson, 1995; Urgeles et al., 1997; Krastel et al., 2001).

At least 52 flank-collapse events, 15 of which have occurred within the last 12 k.y. (Boudon et al., 2007), have been identified in volcanoes of the Lesser Antilles arc (Fig. F1) (Boudon et al., 2007; Deplus et al., 2001; Lebas et al., 2011; Le Friant, 2001; Le Friant et al., 2002, 2003a, 2003b, 2004; Watt et al., 2012). Edifice collapses are a major concern on the small Caribbean Islands, as a large portion of the debris avalanches flow into the sea, generating potentially destructive tsunamis. In the northern part of the arc, flank collapses are repetitive, can occur in all directions, and are promoted by intense hydrothermal alteration and well-developed fracturing of the summit of the edifices. For example, several prehistoric flank collapses have been recognized on the Soufrière Hills Volcano (Fig. F2) (Le Friant et al., 2004; Lebas et al. 2011). The English's Crater event occurred 2000 y ago, producing part of Deposit 1 (volume $=\sim 1.8 \mathrm{~km}^{3}$ ). Debris avalanche Deposit 2 probably resulted from a combined subaerial flank collapse and submarine sediment failure of the eastern flank of the volcano (Le Friant et al., 2004; Lebas et al., 2011; Watt et al., 2012). In the southern part of the arc, flank collapses are larger (with volumes as large as tens of cubic kilometers), always directed to the west, and related to the higher overall slopes of the leeward side of the islands. The evolution of the active Montagne Pelée Volcano has been marked by three major flank collapses (at $0.1 \mathrm{Ma}, 25 \mathrm{ka}$, and $9 \mathrm{ka}$ ) that systematically destroyed the western flank of the volcano (Fig. F3) (Le Friant et al., 2003a; Boudon et al., 2005, 2007). Collapse volumes varied from 2 to $25 \mathrm{~km}^{3}$, and debris avalanches flowed into the Grenada Basin. The Pitons du Carbet Volcano on Martinique experienced a sector collapse at 0.3 Ma (Boudon et al., 1992, 2007; Samper et al., 2007). Dominica has experienced at least three flank collapses and was the site for the generation of the most voluminous mass-wasting deposits in this area, with submarine deposits that cover $3500 \mathrm{~km}^{2}$ (Fig. F4). The proximal debris avalanche deposit consists of megablocks (as long as $2.8 \mathrm{~km}$ and as tall as $240 \mathrm{~m}$ ) that reflect the predominance of lava flows and lava domes, as observed in the source Plat Pays volcanic complex and in terrestrial relict debris avalanche material. Megablocks have been successfully mapped using marine geophysical 
data. In addition, different morphologies and deposit geometries have been observed for Antillean debris avalanche deposits. Large hummocks (as large as $2 \mathrm{~km}$ ) characterize debris avalanches off Dominica, whereas the morphology of several mass-transport deposits off Martinique is smooth. Northern island volcanoes collapse repeatedly, in contrast with southern island volcanoes where collapses are infrequent. Such variations in size and frequency along a volcanic arc have not been previously documented.

Areas of intraplate active volcanism associated with large submarine volcanic landslides have been drilled by the Ocean Drilling Program (ODP), such as Hawaii (ODP Leg 136: e.g., Garcia, 1993; Garcia and Hull, 1994; ODP Leg 200: e.g., Garcia et al., 2006) and the Canary Islands (ODP Leg 157: e.g., Schneider et al., 1997; Goldstrand, 1998; Schmincke and Sumita, 1998). However, all of these drill sites targeted distal turbidites away from proximal debris avalanche deposits and at water depths of $\sim 4000 \mathrm{~m}$ or greater. Seismic surveys around the Canary Islands and the Hawaiian Islands have not penetrated successfully the base of the chaotic unit interpreted as debris avalanche deposit. In contrast, 2-D and 3-D seismic surveys around Montserrat, Martinique, and Dominica have provided excellent images of mass-wasting deposits, including the basal surfaces of these deposits (e.g., Deplus et al., 2001; Le Friant et al., 2003a, 2004, Lebas et al., 2011; Watt et al., 2012; Cassidy et al., in press). Collapse deposits around Montserrat were emplaced in shallow water, whereas offshore Martinique and Dominica, debris avalanches flow into the Grenada Basin. Depositional successions provide good seismic reflectors. Study of these debris avalanche deposits will allow a better understanding of the emplacement processes for these huge masswasting processes.

\section{Sedimentation processes}

The majority of detrital material resulting from the erosion of the islands of the arc is transported into the surrounding ocean (e.g., Sigurdsson et al., 1980; Le Friant et al., 2004; Picard et al., 2006). Studies of offshore deposits from the 1902 eruption of St. Vincent (Carey and Sigurdsson, 1982), from the recent eruption of the Soufrière Hills Volcano (Le Friant et al., 2004; Hart et al., 2004; Trofimovs et al., 2006, 2008, 2012; Le Friant et al., 2009, 2010), and from prehistoric eruptions on Dominica (Sigurdsson et al., 1980; Whitham, 1989) demonstrate that most of the erupted material also reaches the ocean (Le Friant et al., 2010; Wadge et al., 2010). Volcanogenic sediment is channeled by debris flows, turbidity currents, and persistent ocean currents through deep submarine canyons located west of the volcanoes, which, for
Guadeloupe and Dominica, lead into the northern part of the Grenada Basin (Fig. F1).

A stacked series of mixed volcaniclastic-bioclastic turbidites were deposited offshore from southeast Montserrat at $\sim 14 \mathrm{ka}$; these turbitdites contain subequal amounts of bioclastic and volcaniclastic grains (Trofimovs et al., 2012). Much of the bioclastic material originated from shallow water. These stacked turbidites may potentially be sourced from large carbonate platforms associated with islands such as Antigua and Redonda, or they may result from failure of a carbonate platform around Montserrat (Trofimovs et al., 2010). Understanding the origin of these mixed bioclastic-volcaniclastic turbidites is particularly important because the deposit volume exceeds that of volcaniclastic deposits associated with the more recent ( $<100 \mathrm{ka}$ ) eruptions of the Soufrière Hills Volcano. The shallow cores also include other bioclastic dominated turbidites that most likely have local sources. Shallow vibrocores have only recorded bioclastic turbidites associated with the late glacial period. One possibility is that these turbidites are caused by the instability of carbonate platforms during rapid sea level rise at the end of major glaciations. Alternatively, major regional earthquakes may trigger them, in which case the occurrence of such events may be unrelated to climatic cycles.

\section{Submarine alteration of volcanic material}

The nature and timing of submarine alteration of volcanic material likely varies as a function of the chemical species of interest (e.g., high-field strength elements such as Hf and $\mathrm{Zr}$ appear to be largely unaffected, whereas alkali elements can be very mobile), the nature of the volcanic material (e.g., basaltic versus silicic volcanic products and the effect of grain size), and the physical emplacement mechanism (e.g., thin air fall deposits versus thick debris flows). Although there have been sporadic studies of tephra layers at individual Integrated Ocean Drilling Program (IODP) and ODP sites (e.g., Gardner et al., 1986; Gérard and Person, 1994; Martin, 1994; Utzmann et al., 2002), there has been no systematic attempt to study this process as a function of the variables outlined here. Machault (2008) shows that in a piston core sample taken west of Guadeloupe, several tephra layers are correlated with large Plinian eruptions that originated from volcanoes on Dominica (e.g., the Roseau tuff eruption). Chemical analysis (trace and major, incompatible, and immobile elements during the initial alteration stage) of glass from tephra in the cores and from pumiceous deposits on land, combined with mineral assemblages, allows correlation between marine and subaerial pyroclastic deposits. Boudon et al. (2008), Machault (2008), and Sigurdsson et al. 
(1980) show that glass shards in marine sediment in the Caribbean region are not significantly altered.

\section{Site survey data}

Previous work has involved on-land geological, geochemical, petrological, geochronological, and geophysical studies and offshore marine studies. Much of the information is summarized in MacDonald et al. (2000) and in the Volcanic Hazards Atlas of the Lesser Antilles (Lindsay et al., 2005a).

- Drilling at Deep Sea Drilling Project (DSDP) Site 30 during Leg 4 took place in 1969 to investigate the geologic history of Aves Ridge (west of the Grenada Basin). DSDP Site 48 (Leg 15) was located north of Site 30 and was also drilled to investigate the Aves Ridge. However, no DSDP, ODP, or IODP sites have been drilled in the Grenada Basin or close to the Lesser Antilles Islands.

- A regional collection of piston cores was gathered during the Endeavour cruise of 1979, allowing assessment of rates of volcanism and sedimentation, dating of major explosive eruptions, recognition of submarine pyroclastic flow deposits, and establishment of a biostratigraphic framework for the eastern Caribbean (Sigurdsson et al., 1980; Sparks et al., 1980a, 1980b; Reid et al., 1996). Westbrook and McCann (1986) analyzed largescale seismic experimental data on the overall arc crust and show that arc construction has been episodic (e.g., a shift of the axis of volcanism in the Lesser Antilles at the beginning of the Pliocene).

- Marine geophysical data were gathered during two cruises on the $\mathrm{R} / \mathrm{V}$ L'Atalante-Aguadomar (December 1998-January 1999) and Caraval (March 2002) - and one cruise on the RRS James Clark Ross-JCR123 (May 2005). During the first two cruises (Principal Investigators [PIs]: C. Deplus and G. Boudon), Simrad EM12D swath bathymetry and backscatter, $3.5 \mathrm{kHz}$ echo sounder, gravity, magnetic, and six-channel seismic reflection data were collected from Montserrat to St. Vincent (Deplus et al., 2001). During the Caraval cruise, seismic profiles using a 24-channel streamer (Deplus et al., 2002), sediment piston cores, and dredge samples were collected. During the JCR123 cruise (PI: R.S.J. Sparks), >50 sediment cores were collected from around Montserrat to study submarine pyroclastic deposits from the recent eruption (Trofimovs et al., 2006, 2012).

- Two U.K. Natural Environment Research Council (NERC)-funded cruises took place in December 2007. The first cruise (PI: M. Palmer) collected box cores and shallow gravity cores at $\sim 34$ sites around Montserrat to constrain how diagenesis of tephra from recent eruptions influenced seawater geochemistry. The second cruise, a component of the SEA-CALIPSO seismic experiment sponsored by the U.S. National Science Foundation (NSF), NERC, and collaborating agencies (PIs: S. Sparks and B. Voight), aimed at imaging the interior of Montserrat and the Soufrière Hills Volcano using source seismic techniques in combination with 240 onshore seismometers and offshore ocean-bottom seismometers (Voight et al., 2008; Sparks et al., 2008).

- The Gwadaseis cruise (PI: N. Feuillet) of the R/V Suroit (February-March 2009) collected highresolution seismic data and piston cores.

- The JC45/46 cruise (PI: P. Talling) of the RRS James Cook in April-May 2010 collected a dense network of high-resolution 2-D and 3-D seismic data around Montserrat that includes the landslide deposits at Sites U1393, U1394, and U1395 (Lebas et al., 2011; Watt et al., 2012).

\section{Scientific objectives}

Study of volcaniclastic sediment and volcanic landslide deposits drilled in the Lesser Antilles arc will significantly advance our understanding of eruptive history and magmatic evolution in volcanic arcs, as well as the timing and emplacement processes of large debris avalanches. Major advances will result from, for example, recovering the first cores through large-scale volcanic debris avalanches and analyzing the relative timing of eruptions.

We plan to achieve the major objectives of the project by documenting the evolution of three volcanic centers that represent the range of behaviors and eruptive styles in the Lesser Antilles arc: Montserrat in the north, where the Soufrière Hills Volcano has been erupting, resulting in serious hazards and social disruption since 1995; Martinique, with the sadly famous Montagne Pelée Volcano; and Dominica, where several large silicic eruptive centers are considered active, posing serious potential regional hazards because of the occurrence of large-magnitude ignimbrite-forming eruptions. Below, we identify five topics that are linked to the themes of understanding arc volcanic systems and the effects of volcanism on the environment.

\section{Understand the timing and emplacement processes of potentially tsunamigenic large debris avalanche emplacements.}

Volcano flank collapses are increasingly recognized as a normal process in the construction and destruction of volcanic edifices (Ida and Voight, 1995; McGuire, 1996; Voight, 2000). However, several questions regarding the mechanism controlling the 
processes and timing of debris avalanche emplacement are still unresolved. This project was designed to study the architecture of submarine mass-wasting deposits around arc volcanic islands and to specifically try to answer the following questions.

\section{What factors control the timing of large flank failures (Voight, 2000; Voight and Elsworth, 1997)?}

Are flank collapses associated with magmatic intrusions or major volcanic eruptions? Are failures triggered by processes such as more rapid volcano edifice construction, strength reduction by hydrothermal processes, or rapid sea level change (Quidelleur et al., 2008) as might occur in the future? Do flank collapses lead to changes in magmatic evolution by depressurizing the magma system (Voight, 1981; Pinel and Jaupart, 2000; Boudon et al., submitted)?

\section{Does significant erosion occur during the flow of the debris avalanche?}

Are bulking, erosion, and sediment incorporation the same for subaerial and submarine landslides (Glicken, 1991; Komorowski et al., 1991; Voight, 1978; Voight and Sousa, 1994; Schneider et al., 2004)? How large is the volume of reworked sediment? What is the dynamic role of the undrained loading of overridden compressible marine sediment (Voight and Elsworth, 1997)? Is the sedimentary substratum deformed with the emplacement of the debris avalanche (Schneider et al., 2004; Watt et al., 2012)? Are the matrix facies of the debris avalanche more abundant in the bottom part (Gee et al., 1999)?

\section{How might the collapse evolve?}

The collapse might evolve in singular failure or progressively with several closely spaced failures leading to multiple debris avalanches (Wynn and Masson, 2003; Mattioli et al., 2007; Hunt et al., 2011) and proportionately less severe consequences. For instance, large-scale flank-collapse events on the Canary and Hawaiian Islands have generated turbidites that comprise multiple fining-upward subunits with different compositions (Wynn and Masson, 2003; Garcia and Hull, 1994; Hunt et al., 2011), which suggest that flank collapse occurred in a number of stages separated by days to weeks.

\section{Document the long-term eruptive history of the arc to assess volcano evolution (cycles of construction and destruction) and major volcanic hazards.}

It is often difficult to precisely constrain the eruptive history of a volcano beyond the start of written historical records or beyond ages that are greater than those of young well-preserved subaerial tephra fall deposits (commonly only a few thousand years). Marine tephra records in sediment cores collected by piston, gravity, or vibrocoring extend volcanic histories of the Caribbean by several tens of thousands of years (Sigurdsson et al., 1980; Le Friant et al., 2008). However, this improvement is still not sufficient to characterize the evolution of volcanic systems that can extend a few million years or to diagnose the return periods of very large magnitude volcanic events (e.g., explosive eruptions and major flank collapses). This project was designed to answer the following questions: Are the volcanoes as discrete as onshore studies suggest? What are the characteristics of products erupted at the onset of activity from a specific center, particularly those that initially develop below sea level? What processes control migration from one volcanic center to another? Is the end of activity at one center and the onset at another center synchronous, or are there eruptive hiatuses? What is the nature of volcanism during the construction of a volcanic complex? Are there systematic patterns in the time series of volcanic eruptions in terms of eruptive style, eruption magnitude, and repose periods? If so, can these systematic patterns be linked to major processes of volcano construction and destruction (e.g., flank collapse), external factors (e.g., climate and sea level), or deeper magmatic processes?

\section{Characterize the magmatic cycles and long- term magmatic evolution of the arc.}

This objective has common aims with Objective 2, which centers on elucidating volcanic history and behavior. We will use time series and spatial records of variation in magma composition (mineralogy, major and trace element composition, and isotopic signature) and volume to characterize the processes governing magma composition, associated eruption mechanisms, and eruption frequencies. This project was designed to answer the following questions: Why do some magma systems remain steady state for long periods of time generating very similar magma (e.g., Montserrat and Montagne Pelée)? Why do others show much more variability in composition? Why are there marked excursions from mafic to silicic magmatism or vice versa? Are switches in composition sudden or gradual? Can change in composition be linked to major explosive eruptions or flank collapses that perturb the crustal magma systems, or do these changes reflect internal dynamics of crustal magma systems, such as buoyancy instabilities related to accumulation of regions of partial melt?

\section{Document dispersal of sediment into the deep ocean.}

The majority of detrital material resulting from the erosion of the islands of the arc is transported into 
the surrounding ocean (e.g., Sigurdsson et al., 1980; Le Friant et al., 2004; Picard et al., 2006). Our objectives are to contribute to the understanding of sedimentary facies on the submarine flanks and in the basins that surround arc volcanoes, characterize the sedimentation processes, and estimate local sedimentation rates in the northern and southern parts of the arc. This project was designed to answer the following questions: Do debris avalanches have the potential to generate turbidity currents? Are most turbidite units linked to volcanic eruptions? Can some (or many) be linked to nonvolcanic processes such as submarine slope failures triggered by regional earthquakes or gravitational instabilities? What is the proportion of volcanogenic sediment versus hemipelagic carbonate sediment? What are the differences between the north and the south in terms of sedimentation processes?

\section{Determine the processes and element fluxes associated with submarine alteration of volcanic material.}

The processes associated with submarine alteration of magmatic material are of fundamental importance on a global and a regional scale. Drilling will allow the investigation of the little explored issue of the diagenesis of volcanic deposits. This project was designed to answer the following questions: To what extent is volcanic material altered as it is buried and the processes of compaction and diagenesis take place? How does the timing and style of alteration vary as a function of the nature and thickness of the deposit? How does the process of submarine alteration change as a function of parent material composition (basalt, basaltic andesite, andesite, or dacite)?

Answering these questions is not only relevant to furthering our understanding of global biogeochemical cycles but also has implications for the use of geochemical and isotopic systems in dating individual volcanic layers in marine sediment and in correlating volcanic layers between sites.

\section{Coring and drilling strategy}

The main aim of Expedition 340 was the thorough characterization of volcanic and marine sediments at nine primary sites along the backarc region of the Lesser Antilles arc. Generally, achievement of this involved logging and coring as much of the sedimentary sequences as possible in the specified time window, and thus drilling operations were adjusted accordingly.

The originally proposed drilling strategy determined at the precruise meeting in College Station, Texas (USA), in May 2011 was to begin by drilling at proposed Site
CARI-02C (U1393) and end by drilling at proposed Site CARI-09B (U1398) following the sequence laid out in the operations plan (see table T2 in Le Friant et al., 2011). Two holes were planned at each site, with the exception of Site CARI-01C. Site CARI-01C was planned as a single hole, piston cored to a depth of 132 meters below seafloor (mbsf). At all sites, holes would be cored with the advanced piston corer (APC) to refusal. The coring system would then be changed to the extended core barrel (XCB) to core to the total depth as determined by the scientific objectives. However, if coring the first hole fulfilled all scientific objectives, the second hole would not be drilled. In detail, the first and second holes at each site (Holes A and B) would be cored with the APC/ $\mathrm{XCB}$ to the planned depth. After reaching the planned depth, all Hole Bs would be conditioned, displaced with logging mud, and logged, as per the logging plan. While coring, a number of advanced piston coring temperature tool (APCT-3) measurements were also planned, formation conditions permitting. When nonmagnetic barrels were used with the APC, core orientation with the FlexIt tool would be measured for each cored section. If depth objectives could not be achieved with APC/XCB coring, the rotary core barrel (RCB) would be deployed.

The downhole logging program of Expedition 340 was designed to complement the coring program, measuring continuous in situ profiles of physical properties such as bulk density, porosity, resistivity, and natural gamma radiation. Wireline logging was planned for eight of the nine primary sites. Two standard tool strings would be deployed in each logged hole. The first run would be the triple combination (triple combo) tool string, which records resistivity, bulk density, and natural and spectral gamma radiation. The second run would be the Formation MicroScanner (FMS)-sonic tool string, which records gamma radiation, sonic velocity (compressional and shear waves), and oriented high-resolution electrical resistivity images. A third logging run was planned at three sites (CARI-03C, CARI-07C, and CARI-10B) using the Versatile Seismic Imager (VSI) to acquire a zero-offset vertical seismic profile (VSP) for calibrating the integration of borehole and seismic data. At three of the sites (CARI-02C, CARI-03C, and CARI04C), deployment of the Magnetic Susceptibility Sonde (MSS) was planned. The MSS, which measures magnetic susceptibility, would be used to identify flank-collapse deposits from the island of Montserrat, where the volcanic material has a high magnetite content compared to background sediment. During the expedition it was determined that magnetic susceptibility data were valuable for all sites, so the MSS was incorporated into the triple combo tool string for each deployment. 


\section{Principal results}

\section{Site U1393}

\section{Background and objectives}

IODP Site U1393 (proposed Site CARI-02C; $16^{\circ} 43.13^{\prime} \mathrm{N}, 62^{\circ} 5.06^{\prime} \mathrm{W}$; 914 meters below sea level [mbsl]) is located close to the Soufrière Hills Volcano on Montserrat $(7.4 \mathrm{nmi}$ [13.7 km] from Point Shoe Rock, at the southeast tip of Montserrat) (Fig. F2; Table T1).

The ongoing eruption of the Soufrière Hills Volcano on Montserrat started in 1995. Activity has included lava dome growth, pyroclastic flows from dome collapse, explosive activity with tephra fall and pumice flows, flank collapse with debris avalanches, and volcanic blasts. More than $70 \%$ of erupted material from the ongoing eruption has been transported to the sea (Le Friant et al., 2009, 2010; Trofimovs et al., 2006). The rapid deposition of volcanic material into the sea has caused small tsunamis (Herd et al., 2005).

Site survey data indicated that distal parts of the pyroclastic flows and some underlying, older chaotic deposits interpreted as debris avalanches have been deposited at Site U1393. The English's Crater event, which occurred 2000 y ago, produced Deposit 1 (Boudon et al., 2007). The deeper deposit (Deposit 2) probably resulted from a combined submarine and subaerial mass-wasting process of the eastern flank of the volcano, which included failure and deformation of submarine sediment (Le Friant, 2004; Lebas et al., 2011; Watt et al., 2012). Seismic data indicated that drilling at Site U1393 could penetrate through the erupted material from the ongoing eruption and into the underlying Deposits 1 and 2 .

The objective for Site U1393 was to characterize the processes occurring during debris avalanche emplacement, associated erosional processes, and tephra diagenesis. Analysis of $5 \mathrm{~m}$ piston cores taken in this area shows that pyroclastic material from the 2003 Soufrière Hills Volcano lava dome collapse mixed with seawater and immediately deposited the coarse components out of suspension (Trofimovs et al., 2006). Study of the coarse debris avalanche deposit will enhance our understanding of emplacement processes.

Comparing the geochemical signatures (pore water and sediment) of cored material with surface sediment (from the 2007 NERC cruise) will allow us to characterize the alteration rates of volcanic material in seawater. In addition, we will examine the dependency of alteration rate and style on grain size, layer thickness, and admixture of sediment.

Cores from Deposit 1 (smaller volume) and Deposit 2 (larger volume) will allow us to compare the emplace- ment processes of mass-transport deposits of different magnitudes. We plan to undertake a detailed lithologic, sedimentologic, and textural fabric analysis of the retrieved material at macro- and microscopic scales to investigate transport and deposition processes, the nature and magnitude of erosional processes, and interaction with the substratum (e.g., bulking) (Komorowski et al., 1991; Glicken, 1991, 1996). These data will provide valuable insights into chronology (one or several pulses) and debris avalanche mobility, which have implications for tsunami genesis.

\section{Scientific results}

\section{Lithostratigraphy}

Based on the lithologic characteristics of sediment recovered at Site U1393, only one lithostratigraphic unit, Unit A, was defined (Fig. F5). Unit A extends from the seafloor to 4.24 mbsf; however, the lower stratigraphic boundary of this unit cannot be defined because of poor core recovery. The upper part of Unit A consists of mud clasts embedded in a sandy matrix. This lithology is followed downhole by dark brownish gray-black sand consisting of volcaniclastic material containing medium to very coarse sandsized grains. Grains are composed mainly of andesite and rarely of carbonate. Occasionally, larger clasts of amphibole-rich andesite are present. The unit is moderately well to well sorted, massive, and normally graded. The lowest part of Unit A consists of andesite clasts as large as $3 \mathrm{~cm}$ embedded in a coarse sand matrix. Below Unit A, the material recovered consists mainly of andesite clasts. These clasts show variable signs of hydrothermal alteration and subaerial oxidation, and some large clasts were abraded and possibly broken during coring and recovery. The uppermost $4.24 \mathrm{~m}$ of the material cored is a product of the most recent eruption of the Soufrière Hills Volcano.

\section{Paleontology and biostratigraphy}

Generally, the core catchers retrieved at Site U1393 contain very few micro- and nannofossils, which is consistent with the lithostratigraphic information at this site. Because of the small number of fossils, an age determination of the cored material was not possible. However, the four observed benthic foraminifers are typical for a shallow-water reef environment, suggesting transport and reworking.

\section{Physical properties}

Physical properties data obtained on the cored material are typical of well-sorted sand with an andesitic bulk composition (Fig. F5). The measured grain density of $2.80 \mathrm{~g} / \mathrm{cm}^{3}$ and the measured bulk porosity of $42 \%$ are consistent with an andesitic composition and medium- to well-sorted sand that has undergone 
little consolidation. Magnetic susceptibility (maximum value of $2550 \times 10^{-5} \mathrm{SI}$ at $1.07 \mathrm{mbsf}$ ) of the material dominated by volcaniclastic particles is much higher than that in hemipelagic sediment. Mean $P$-wave velocity is $1750 \mathrm{~m} / \mathrm{s}$.

\section{Paleomagnetism}

Meaningful paleomagnetic directions for the interpretation of the geomagnetic field at Site U1393 could not be obtained, primarily because of the sediment composition, sediment grain size, and consolidation state of the material recovered.

\section{Site U1394}

\section{Background and objectives}

IODP Site U1394 (proposed Site CARI-03C; $\left.16^{\circ} 38.43^{\prime} \mathrm{N}, 62^{\circ} 2.29^{\prime} \mathrm{W} ; 1115 \mathrm{mbsl}\right)$ is located off the island of Montserrat $(\sim 13 \mathrm{nmi}$ [24 km] from Point Shoe Rock, at the southeast tip of Montserrat) (Fig. F2; Table T1).

Site survey data obtained for Site U1394 revealed the presence of chaotic deposits interpreted as debris avalanche deposits (Deposit 2 and underlying Deposit 8 ) and indicated that drilling could penetrate through multiple units of debris avalanche Deposit 2 (Lebas et al., 2011; Watt et al., 2012). We planned to drill $244 \mathrm{~m}$ through volcanic and biogenic sediment with intercalated chaotic debris avalanche Deposit 2.

The objective for Site U1394 was to characterize processes that occur during debris avalanche emplacement and associated erosional processes. Study of the sediment overlying the mass-transport deposit will allow us to date the associated event using $\delta^{18} \mathrm{O}$ chronostratigraphy. We will be able to determine whether the mass-wasting process occurred as a single event or as a series of closely spaced, separate events. Utilizing a combination of detailed lithologic, sedimentologic, and textural fabric analyses, we will be able to test the hypothesis that the debris avalanche incorporated sediment eroded from the seafloor during its emplacement. We hoped to reach the bedded units below the chaotic debris avalanche unit and thus investigate the textural and structural characteristics of the base of the debris avalanche (Komorowski et al., 1991; Glicken, 1991, 1996). Existing numerical models of debris avalanche emplacement do not sufficiently consider the interaction of the debris avalanche with the substratum and its influence on the mobility of the flow. Our goal was to look for structural evidence of the development of shear zones from the base of the debris avalanche into the overlying plug and fluidization structures (clastic dikes) described in terrestrial debris avalanche deposits (e.g., Glicken, 1996; Voight et al., 2002; Gee et al., 1999; Clavero et al., 2002; Shea et al., 2008).

\section{Scientific results}

\section{Lithostratigraphy}

The main lithologies cored at Site U1394 are hemipelagic mud, turbiditic sand and mud, mafic volcaniclastics, and tephra (Figs. F6, F7). The hemipelagic mud mainly consists of fine-grained calcareous biogenic fragments and siliciclastic sediment. It is often pale yellowish gray to dark gray in color, varies from fine silt to fine mud in grain size, and is moderately to poorly sorted. The turbiditic sand and mud lithology is characterized by normally graded, massive, well-sorted mud (for thin deposits a few centimeters thick) to very coarse sand (for meter-thick deposits) consisting of volcaniclastic and bioclastic particles. Volcaniclasts include fragments of fresh andesitic lava and pumice, altered lava, and crystals (feldspar, amphibole, etc.). Bioclasts include fragments of carbonate materials such as coral and shells. The ratio of volcaniclastic to bioclastic components varies. Mafic volcaniclastics consist of basaltic turbidites. Tephra deposits retrieved from this site are composed of fining-upward units of normally graded (from pebble to fine sand) basaltic particles and basaltic scoria. The fining-upward units vary in thickness from 6 to $13 \mathrm{~cm}$ (Hole U1394A) and from 13 to $30 \mathrm{~cm}$ (Hole U1394B).

Investigation of the main lithologies by X-ray diffraction (XRD) shows that the pelagic sediment intervals predominantly contain calcite and high-Mg calcite plus or minus aragonite, together with minor volcanic phases (mostly plagioclase with lesser orthopyroxene and hornblende) and amorphous clay minerals. Samples from the volcaniclastic horizons contain dominant plagioclase and lesser amounts of orthopyroxene and hornblende, as well as minor sedimentary carbonate. One of the investigated tephra layers contains abundant smectite in addition to the volcanic minerals and background pelagic phases noted above. The $\mathrm{CaCO}_{3}$ content of the cored material is higher in the largely pelagic sections, with some values $>60 \%$, than in the units more dominated by volcanic turbidites. However, the presence of smaller quantities (i.e., $<20 \%$ ) of $\mathrm{CaCO}_{3}$ in the latter still indicates a biogenic component and is consistent with visual inspection of the core. Organic carbon concentrations in the pelagic sections range as high as $1 \mathrm{wt} \%$ or higher, with values in the turbiditic section as low as $<0.2 \mathrm{wt} \%$.

Based on abrupt or gradational changes in the abundance of these lithologies and distinctive marker horizons (tephras and turbidites), six lithostratigraphic units, termed Units A-F, were defined. Unit $\mathrm{A}$ is divided into seven subunits (A-1 to A-7). Unit A ( $7 \mathrm{~m}$ thick) consists of a series of volcaniclastic turbidites with varying proportions of bioclastic 
particles separated by variably thick hemipelagic sediment consisting of mud to rarely silty mud. Turbidites generally fine upward from a sandy base into a muddy top. A basaltic tephra layer marks the base of the unit. Unit B is $\sim 43 \mathrm{~m}$ thick. The upper part of Unit B consists of a fairly thick interval of relatively coarse grained, stacked, and amalgamated turbidites ranging in composition from bioclastic to volcaniclastic. The turbidites are always massive and planar with ripple cross-lamination always absent, suggesting rapid deposition that prevented bed-load reworking into laminae. Below this interval, turbidites are flat lying, relatively thin, and sometimes weakly deformed. The thick turbidite interval is separated from the thin layer of turbidites by an interval of very contorted hemipelagic silty mud with fine laminae. Unit C ( $\sim 24 \mathrm{~m}$ thick) contains alternating sequences of hemipelagic sediment and volcaniclastic turbidites. Individual intervals of hemipelagic sediment are as thick as $130 \mathrm{~cm}$. Unit D $(\sim 18 \mathrm{~m}$ thick in Hole U1394A; $36 \mathrm{~m}$ thick in Hole U1394B) is dominated by massive coarse-grained turbiditic sand composed of variable amounts of volcaniclastic and bioclastic material. Turbidites are either graded or ungraded. Chaotically distributed clasts (andesitic and biogenic) up to several centimeters in length in some ungraded sections may suggest en masse emplacement by debris flows. Unit E ( 90 m thick in Hole U1394A; $\sim 70 \mathrm{~m}$ thick in Hole U1394B) contains significant amounts of hemipelagic mud alternating with turbidites, which consist mainly of volcaniclastic or bioclastic material or a mixture of both. The upper part of Unit E contains relatively thick and coarse-grained turbidites; turbidites are less abundant and thinner in the middle part of Unit E. Turbidite thickness increases again near the base of the unit. Distributed throughout Unit $\mathrm{E}$ are massive brown ash layers, some of which are $20 \mathrm{~cm}$ thick, and layers of pumice clasts (as wide as $5 \mathrm{~cm}$ in diameter). Unit F ( $\sim 35 \mathrm{~m})$ is only recognized in Hole 1394A and its base was not reached. It is poorly recovered, but consists of coarsegrained andesitic clasts.

A closer investigation of the volcaniclastic and fallout deposits based on thin section microscopy shows that recovered clasts of andesitic lava and pumice fragments consist of plagioclase (70\%), amphibole (25\%), Fe-Ti oxides (4\%), and orthopyroxene phenocrysts (1\%). In the andesites, phenocrysts are contained in a microcrystalline matrix of plagioclase, oxides, and pyroxene microlites. The groundmass of the investigated pumice particles is significantly different. It consists of glassy material exhibiting considerable flow lineation. No flow lineation was observed in the lava clasts. The groundmass to phenocryst ratios are approximately 60:40 and 70:30 for andesite and pumice, respectively. Microscopic investigation of the tephra layers revealed that the uppermost tephra layer is basaltic in composition, containing fragments of plagioclase, olivine, clinopyroxene, and oxides in descending abundance. The deeper layers are of basaltic andesitic or andesitic composition, containing fragments of plagioclase, amphibole, orthopyroxene, and Fe-Ti oxides.

\section{Paleontology and biostratigraphy}

The microfossil content of the sediment described above are consistent with their intensely reworked nature. Calcareous nannofossils and planktonic and benthic foraminifers of varying abundances and levels of preservation were observed. Volcanic clasts, coral fragments, highly fragmented foraminifers, and abundant reef-dwelling benthic foraminifers are observed in the majority of core catcher samples. Biostratigraphic datums derived from both calcareous nannofossils and planktonic foraminifers show that Site U1394 contains many levels of reworked sediment from the early Pleistocene amidst a background of late Pleistocene sedimentation.

The observed nannofossils generally show extremely poor preservation, and their abundance is low. Typical nannofossil species observed within the cored sediment are Gephyrocapsa caribbeanica, Pseudoemiliania lacunosa, Calcidiscus leptoporus, and Helicosphaera kamptneri. Helicosphaera inversa is a very important species because of its short range through the early and late Pleistocene (upper Zone CN13 through Zone CN14), assigning the cored materials to the Pleistocene. Reworking of the sediment is also indicated by the occurrence of Helicosphaera sellii (Zones CN10-CN13) in a number of samples. Globigerinoides ruber (white) and Globigerinoides sacculifer dominate the planktonic foraminifers observed at Site U1394. Other abundant species include Globigerina falconensis, Globigerinita glutinata, Globigerinoides elongatus, Globorotalia tumida, and Neogloboquadrina dutertrei (dextral). Planktonic foraminifer species present are indicative of warm subtropical waters. Three marker species were commonly encountered-Globorotalia flexuosa (0.07-0.40 Ma), Globigerinella calida (base occurrence $[\mathrm{B}]$ at $0.22 \mathrm{Ma}$ ), and Globorotalia tosaensis (top occurrence $[\mathrm{T}]$ at $0.61 \mathrm{Ma}$ )-assigning the investigated sediment, in accordance with nannofossil observations, to within the Pleistocene. The presence of the benthic foraminiferal species Osangularia, Globocassidulina, Cibicides, and Laticarinina pauperata suggests a bathyal paleodepth for Site U1394.

\section{Paleomagnetism}

Through measurement of the natural remanent magnetization (NRM) all superconducting rock magnetometer (SRM) and discrete inclination data record normal polarity. We see no evidence for reversed 
polarity in the record, particularly in the lower part of the record where data coverage is better. Because of the lack of a continuous record, we cannot unequivocally say that all sediment was deposited within the Brunhes chron; however, this would indicate a late Pleistocene age for the site, which agrees with biostratigraphic ages.

\section{Physical properties}

Physical properties of material retrieved at Site U1394 can generally be correlated to lithologic variations, including composition, grain size, and observed lithification (Figs. F6, F7). Bioclastic and volcaniclastic turbidites, as well as thick tephra layers, can be discerned from background sedimentation (carbonate ooze) by most of the physical properties (Fig. F7). The hemipelagic mud generally shows little variation and has low magnetic susceptibility $\left(200 \times 10^{-5}\right.$ to $400 \times 10^{-5} \mathrm{SI}$ ), low $P$-wave velocity, and relatively high natural gamma radiation (NGR). In contrast, the physical properties of turbidites are relatively heterogeneous, with overall high values of magnetic susceptibility (average $=740 \times 10^{-5} \mathrm{SI}$ ) and $P$-wave velocity but low NGR. This is typical for these materials, as the products of volcanic eruptions usually have higher iron content than hemipelagic sediment, whereas NGR is usually higher in hemipelagic sediments (e.g., U content in hemipelagic sediment is higher than that found in volcanic products). Single bioclastic and volcaniclastic turbiditic units throughout both holes can be traced by their uphole monotonically decreasing values in magnetic susceptibility, $P$-wave velocity, and density, mimicking their grading in grain size. A sharp drop in each of these values occurs at the boundaries of the turbiditic units. Where sufficiently thick, ash layers give positive peaks in magnetic susceptibility. Between 10 and 15 mbsf, magnetic susceptibility, density, and NGR data systematically differ in Holes U1394A and U1394B. This pattern is consistent with differences in lithologies retrieved from both holes. Hole U1394A is dominated by dark, dense turbidites with andesitic composition at this interval, whereas lighter colored pumice-rich deposits were cored in Hole U1394B. $P$ wave velocity averaged $1614 \mathrm{~m} / \mathrm{s}$. The mean thermal conductivity is $1.03 \pm 0.07 \mathrm{~W} /(\mathrm{m} \cdot \mathrm{K})$ with a standard error on the mean of $0.01 \mathrm{~W} /(\mathrm{m} \cdot \mathrm{K})$. These values are similar to expected values for high-porosity sediment. The measured porosity of hemipelagic samples ranges from $48 \%$ to $66 \%$. Turbidites display porosity values between $42 \%$ and $60 \%$. Bulk density of the hemipelagic sediment ranges from 1.52 to $1.85 \mathrm{~g} / \mathrm{cm}^{3}$, whereas bulk density of the turbiditic sediment ranges from 1.65 to $2.08 \mathrm{~g} / \mathrm{cm}^{3}$. Grain density values of the hemipelagic sediment exhibit a narrow range of $2.63-2.79 \mathrm{~g} / \mathrm{cm}^{3}$, whereas grain density values obtained from turbidite samples show a slightly larger range of $2.6-2.9 \mathrm{~g} / \mathrm{cm}^{3}$. Turbidites consisting of a mixture of bioclastic and volcaniclastic material have grain densities $\leq 2.79 \mathrm{~g} / \mathrm{cm}^{3}$.

\section{Downhole logging}

In situ measurements of geophysical properties obtained by downhole logging operations are in general agreement with physical properties data obtained from the cores (Fig. F7). Gamma radiation data do not exhibit a clear downhole trend over the measured interval, but generally the fine-scale variations in total gamma radiation have a higher frequency above 110 mbsf than below this depth. This change seems to coincide with a change from stacked turbidites into a series of alternating turbidites and hemipelagic sediment. Sonic velocities generally increase downhole, ranging from 1650 to $1900 \mathrm{~m} / \mathrm{s}$. Distinctive local peaks in compressional velocity $\left(V_{\mathrm{P}}\right)$ coincide with increased resistivity and magnetic susceptibility, corresponding most likely to similarly scaled turbiditic units identified in the cores.

\section{Geochemistry}

In addition to studies done on retrieved sediment, pore water samples obtained from hemipelagic sediment were also analyzed. Pore water samples from turbiditic units were generally not obtained because it is not possible to collect meaningful pore water data from such highly permeable material. Pore water samples were largely taken from intervals dominated by pelagic carbonate. Alkalinity values increase from $3.3 \mathrm{mM}$ in the uppermost section to a consistent value of $11.5 \mathrm{mM}$ at roughly the middle of the hole before decreasing to $7.5 \mathrm{mM}$ at the base of the hole. $\mathrm{pH}$ values remain relatively constant at 7.4-7.5 throughout the hole. Of the major cations, calcium decreases from values close to bottom water in the uppermost sample to a minimum at roughly the middle of the hole before increasing toward the bottom, whereas magnesium monotonically decreases with depth, with the exception of the deepest sample (Fig. F7). Sodium and potassium concentrations show a weak increase and decrease with depth, respectively. $\Sigma S$ concentrations show a similar pattern to those of calcium. Chloride concentrations fluctuate within the normal range $(550-580 \mathrm{mM})$ expected for pore water obtained from squeezing carbonate sediment. Generally, pore water data are consistent with diagenesis of carbonate-rich sediment with organic carbon concentrations that are typical of an open marine setting. 


\section{Site U1395}

\section{Background and objectives}

IODP Site U1395 (proposed Site CARI-04D; $16^{\circ} 29.60^{\prime} \mathrm{N}, 61^{\circ} 57.09^{\prime} \mathrm{W} ; 1191 \mathrm{mbsl}$ ) is located between Guadeloupe and Montserrat (Fig. F2; Table T1).

According to the site survey data, Site U1395 is located beside Deposit 2. Seismic reflection profiles indicated that drilling at Site U1395 could penetrate a succession of hemipelagic sediment and turbidites. The proposed total depth for this site was 244 mbsf.

The objective for Site U1395 was to characterize the sedimentation processes related to volcanic activity in the Bouillante-Montserrat half graben. We planned to drill through hemipelagic sediment, turbidites, and tephra to retrieve a complete record of sediment. Work around the Canary Islands has shown that distal volcaniclastic turbidites generated by collapse events can be used to study the gross character of landslide emplacement (Wynn and Masson, 2003; Hunt et al., 2011). Results from ODP Hole 1223A off Hawaii identified the association of several turbiditic deposits with landslides, showing that the Koolau Volcano collapsed repeatedly and that landslides constituted a greater risk than previously thought (Garcia et al., 2006). Analysis of cores taken during the JCR123 cruise suggests that distal turbidites associated with Montserrat provide a record of all main pyroclastic flow events that entered the ocean during the current eruptive phase (since 1995). Information from these cores also records the waxing and waning phases of individual dome collapses (Trofimovs et al., 2006). Turbidites in cores recovered from this site should therefore provide a record of dome and flank collapses. With the retrieved material, it will also be possible to better constrain the long-term sedimentation rate in the northern part of the arc.

\section{Scientific results}

\section{Lithostratigraphy}

The main lithologies cored at Site U1395 resemble those cored at Site U1394 (Figs. F8, F9). Based on abrupt or gradational changes in the abundance of these lithologies or on distinct marker horizons (e.g., tephra layers), the material was divided into nine lithostratigraphic units (Units A-I). Generally, each unit consists of various combinations of hemipelagic mud, turbiditic sand and mud, and tephra. Unit A is $10 \mathrm{~m}$ thick and is similar to Unit A at Site U1394. It consists of volcaniclastic and mixed bioclastic-volcaniclastic turbidites interbedded with hemipelagic background sediment. Unit A is divided into seven subunits (A-1 to A-7). Unit B is $\sim 6 \mathrm{~m}$ (Hole U1395A) and $4 \mathrm{~m}$ (Hole U1395B) thick and consists of a sequence of thick, stacked volcaniclastic turbidites, showing normal grading from very coarse to very fine sand. The matrix of these turbidites is mainly composed of dense to vesicular lava fragments, pyroxenes, amphiboles, and feldspars with a very low, or no, carbonate fraction. Occasionally, larger pumice clasts (as large as $2 \mathrm{~cm}$ ) are present in this unit. Unit $C$ consists of a $65 \mathrm{~cm}$ thick layer of hemipelagic sediment. Unit D, which is $\sim 2 \mathrm{~m}$ (Hole U1395A) and $3 \mathrm{~m}$ (Hole U1395B) thick, is composed of another sequence of thick, stacked volcaniclastic turbidites similar in appearance to the turbidites in Unit B. However, in Hole U1395B, Unit D turbidites show a much higher content of large pumice (1-4 cm in diameter) particles dispersed throughout the entire matrix of the turbidites. Unit D is followed by a thick sequence $(43 \mathrm{~m})$ of mainly hemipelagic sediment, defined as Unit E. Intercalated throughout this sequence are a small number of relatively thin sandy turbidites, consisting of volcaniclastic, bioclastic, or mixed bioclastic-volcaniclastic particles. Additionally, several volcanic fine sand layers are identified in this unit, as well as some partly well sorted pumice deposits. Unit $\mathrm{F}$ is $\sim 19 \mathrm{~m}$ thick and is also composed of thick, stacked turbiditic sequences interrupted by hemipelagic sediment. Unit $\mathrm{F}$ is divided into three subunits (F-1 to F-3). The upper part of Unit F (Subunit F-1) is composed of a thick, dark, homogeneous turbidite consisting of mixed bioclastic-volcaniclastic material. The majority of this turbidite is ungraded, with normal grading occurring only in the uppermost part, followed by a layer of hemipelagic sediment with intercalated layers of sand-sized bioclastic and volcaniclastic particles. These layers are massive to normally graded, changing from very fine to medium sand. The lower part of Unit F (Subunit F-2) is mainly composed of hemipelagic sediment with intercalated sandy bioclastic or volcaniclastic layers. Unit $\mathrm{G}(\sim 31 \mathrm{~m}$ thick) is divided into two subunits (G1 and G-2). Subunit G1 consists of hemipelagic sediment interbedded with sand-sized volcanic material consisting of lava fragments, scoria, plagioclase, pyroxene, and rare amphibole. Amphibole appears only in a few layers (without clinopyroxene) and is characteristic of tephra deposits originating from volcanoes in the central part of Guadeloupe. Tephras are particularly abundant between 90 and $100 \mathrm{mbsf}$ (Core 12H for Holes U1395A and U1395B). In Hole U1395B, a succession of volcaniclastic turbidites also occurs in Subunit G-1. Subunit G-2 is characterized by highly contorted and deformed hemipelagic sediment. Unit $\mathrm{H}$, which is $\sim 8-11 \mathrm{~m}$ thick, is composed of a thick sequence of pumice-rich turbiditic deposits showing normal grading, with a matrix dominantly composed of crystals, lava clasts, and minor pumice and carbonates. Unit I (121 mbsf to the base of Hole U1395A and 124 mbsf to the base of Hole U1395B) 
consists of semiconsolidated silt- and mudstones, most of which are heavily bioturbated.

XRD and carbonate analysis performed on 44 individual samples taken throughout the entire cored interval shows results similar to analyzed samples from Site U1394. Samples of pelagic sediment are characterized by calcite, high-Mg calcite plus or minus aragonite, and minor volcanic phases such as plagioclase, orthopyroxene, and hornblende. The clay minerals detected are kaolinite, smectite, and glauconite. Samples from the volcanic-rich horizons contain dominant plagioclase, lesser amounts of orthopyroxene and hornblende, and minor carbonate.

$\mathrm{CaCO}_{3}$ content is much higher in the largely pelagic sections in the upper part of this hole ( $>30 \%)$ than in the largely volcanic turbidites. The presence of a few weight percent $\mathrm{CaCO}_{3}$ in the latter indicates a significant biogenic component. $\mathrm{CaCO}_{3}$ content is highest (as high as 88\%) in the semilithified sediment toward the base of the hole. Organic carbon concentrations in the pelagic sections can exceed $1 \mathrm{wt} \%$ but are much lower in the turbidite sections. Organic carbon concentrations also increase toward the base of the hole (as high as $1.5 \mathrm{wt} \%$ ). The ratio of organic carbon to $\mathrm{CaCO}_{3}$, however, remains relatively constant in hemipelagic intervals throughout the hole, suggesting that the concentration increases simply reflect less dilution by volcanic material at depth.

\section{Paleontology and biostratigraphy}

Biostratigraphic studies of the cored material were limited by its coarse nature. Site U1395 core catcher samples contain calcareous nannofossils and planktonic and benthic foraminifers of varying abundances and at varying levels of preservation. Generally, preservation deteriorates with depth, making the samples increasingly difficult to date. Both nannofossil and planktonic foraminiferal biostratigraphic datums for this site indicate ages of deposition ranging from late Pleistocene to early Pleistocene. Three different nannofossil assemblages were observed with increasing depth: first, within the top this site are Geophyrocapsa oceanica, Rhabdosphaera clavigera, Geophyrocapsa muellerae, Helicosphaera kamptneri, and Helicosphaera hyalina. Pseudoemiliania lacunosa was not found in the uppermost core at this site, dating the uppermost sample to $<0.289 \mathrm{Ma}$. Below, typical species present were P. lacunosa, Ceratolithus cristatus, H. hyalina, Calcidiscus leptoporus, R. clavigera, Calciosolenia murrayi, and Syracosphaera pulchra. Lastly, in the lower portion of the site, a nannofossil assemblage typical for the early Pleistocene with Gephyrocapsa caribbeanica, P. lacunosa, Coccolithus leptoporus, and Crenalithus doronicoides was observed. C. doronicoides was detected in Sample 340-U1395A-12H-CC, the first sample below the lowest occurrence of $G$. oceanica, indicating that this sediment is within nannofossil Subzone CN13b. The assemblage of planktonic foraminifers observed in the cored material is generally characteristic for subtropical waters and is dominated by Globigerinoides ruber (white) and Globigerinoides sacculifer. Other abundant species include Globigerina falconensis, Globigerinita glutinata, Globigerinoides elongatus, Globorotalia tumida, and Neogloboquadrina dutertrei (dextral). Three biozones were recorded, PT1b, PT1a, and PL6, with PL6 in the bottom sample of this site. The primary marker between Zones PT1a and PL6 was not recorded; however, Zone PL6 was recognized based on the presence of Globorotalia exilis (T 2.1 Ma) instead, a secondary datum within Zone PL6. Several additional secondary datums were recorded as well: Globorotalia flexuosa (0.07-0.40 Ma), Globigerinella calida ( $0.22 \mathrm{Ma}$ ), and Globorotalia tosaensis ( $\mathrm{T}$ $0.61 \mathrm{Ma}$ ). The presence of the benthic foraminiferal species Uvigerina auberiana, Laticarinina pauperata, Bulimina aculeata and the genus Osangularia suggests a bathyal paleodepth for this site. In addition to the micro- and nannofossils obtained at this site, sponge spicules, pteropods, and heteropods are also abundant and generally well preserved in the upper samples. Otoliths are present throughout the core samples, and four different morphotypes are present. Ostracods when present are rare.

\section{Paleomagnetism}

Interpretation of the NRM of the recovered cores is based on the hemipelagic sediment, as it is potentially the least disturbed and most optimal sediment to hold information about the behavior of the geomagnetic field during deposition. Inclination data obtained cluster and plot around the expected inclination $\left( \pm 30.6^{\circ}\right)$, assuming a geocentric axial dipole (GAD) for the site. With FlexIt tool reorientation, both inclination and declination in Hole U1395A show the Brunhes/Matuyama boundary $(0.78 \mathrm{Ma}$; Cande and Kent, 1995) at $~ 66$ mbsf (Figs. F8, F9). A turbidite masks the Brunhes-Matuyama transition in Hole U1395B, but it occurs between 71.9 mbsf (reversed polarity) and 67.7 mbsf (normal polarity). Based on inclinations obtained from the measurement of discrete samples in conjunction with declination data obtained from entire cores, the transition from the Jaramillo (normal) to the Matuyama (reversed) (0.99 Ma; Cande and Kent, 1995) occurs at 90 mbsf in both holes. A sequence of unconsolidated tephras and turbidites, severely faulted and altered sediment, and poor recovery below $100 \mathrm{mbsf}$ at Site U1395B make further interpretation of polarity difficult. Sedimentation rates for the uppermost $100 \mathrm{~m}$ of the site are therefore on the order of $8 \mathrm{~cm} / \mathrm{k} . \mathrm{y}$. during the Brunhes Chron, with slightly higher rates at the end 
of the Matuyama Chron ( $11 \mathrm{~cm} / \mathrm{k} . \mathrm{y}$.$) , or 9 \mathrm{~cm} / \mathrm{k} . \mathrm{y}$. for the whole record. The four deepest discrete inclination samples may indicate a polarity change indicative of the beginning of the normal Jaramillo Chron (1.070 Ma) at 101 mbsf (Hole U1395A) and $116 \mathrm{mbsf}$ (Hole U1395B), but this needs further investigation.

\section{Physical properties}

Similar to Site U1394, the physical properties of the material retrieved at Site U1395 can be correlated to lithologic variations observed in the recovered material (Figs. F8, F9). This includes compositional variations and differences in grain size and lithification stage. Based on magnetic susceptibility data, it is possible to clearly identify volcanic material retrieved in the cores. Volcaniclastic layers and turbidites exhibit pronounced positive anomalies of as much as $2800 \times$ $10^{-5} \mathrm{SI}$; ash layers show the same behavior, but the magnitude of the signal is generally smaller, with typical values of $700 \times 10^{-5}$ to $1500 \times 10^{-5}$ SI. Hemipelagic sediment and bioclastic turbidites have generally low and relatively constant magnetic susceptibility $\left(<350 \times 10^{-5}\right.$ and $<700 \times 10^{-5} \mathrm{SI}$, respectively). Variations in NGR are usually antithetic to the magnetic susceptibility signature. NGR is generally low in the retrieved volcaniclastic material (typically 3-5 cps) and relatively high in the hemipelagic sediment (around 10 cps). Bulk densities vary throughout the cored material with high values (as high as $2.0 \mathrm{~g} / \mathrm{cm}^{3}$ ) in turbidites that contain dense volcanic clasts but relatively low values for bioclastic turbidites. The lowest bulk density values are observed for turbidite units containing coarse pumice clasts. Porosity ranges from $\sim 48 \%$ to $67 \%$ and displays a weak negative trend with depth. Grain density of the hemipelagic samples has a narrow range of 2.65$2.8 \mathrm{~g} / \mathrm{cm}^{3}$. Grain density of the pumice-rich turbidite is lower, ranging between 2.45 and $2.55 \mathrm{~g} / \mathrm{cm}^{3}$. Generally, volcaniclastic turbidites have higher velocities $(1750-1800 \mathrm{~m} / \mathrm{s})$ than hemipelagic sediment (1500$1600 \mathrm{~m} / \mathrm{s})$. $P$-wave velocities obtained from discrete samples of the split core generally agree with velocities obtained on the whole core. Downhole formation temperature was measured at 24.9, 34.4, and $43.9 \mathrm{mbsf}$ in Hole U1395B. The temperature gradient is $98.2 \pm 8.8^{\circ} \mathrm{C} / \mathrm{km}$. Using the measured thermal conductivity of $1.029 \mathrm{~W} /(\mathrm{m} \cdot \mathrm{K})$, with a standard error on the mean of $0.017 \mathrm{~W} /(\mathrm{m} \cdot \mathrm{K})$, the implied heat flow is $0.101 \pm 0.009 \mathrm{~W} / \mathrm{m}^{2}$. This is the highest heat flow of all sites visited during Leg 340. The corrections to this heat flow from sedimentation and bathymetry are negligible (Manga et al., 2012).

\section{Downhole logging}

In situ measurements of geophysical properties obtained by downhole logging (Fig. F9) resulted in the differentiation of three logging units (1-3). Logging Unit 1 (85-112 mbsf) is characterized by relatively consistent downhole profiles in density, resistivity, and $P$-wave velocity, all of which exhibit low-amplitude variability. $P$-wave velocities slightly increase with depth from $\sim 1550 \mathrm{~m} / \mathrm{s}$ at the top to $\sim 1620 \mathrm{~m} / \mathrm{s}$ at the base of the unit. Logging Unit 2 (further divided into logging Subunits 2A and 2B) is generally distinguished from logging Unit 1 by a sharp decrease in gamma radiation and increases in density and resistivity, as well as a broad change in the character of the logging profile. Gamma radiation, density, resistivity, and $P$-wave velocity all show high-amplitude variations. The drop in gamma ray intensity, associated with an increase in density and resistivity, might be an indication for turbidites in this interval. Logging Unit 3 (163-202 mbsf) is characterized by a return to lower frequency variations in all geophysical property measurements, similar to what is displayed in logging Unit 1. $P$-wave velocities subtly increase with depth, with the average value being higher in this lower unit than in the upper one; this is consistent with a classic compaction trend.

\section{Geochemistry}

In addition to studies done on the retrieved sediment, headspace gas samples and pore water samples obtained from hemipelagic sediment were also analyzed. Pore water samples from turbiditic units were generally not obtained because it is not possible to collect meaningful pore water data from such permeable material. Alkalinity values increased from $3.5 \mathrm{mM}$ in the uppermost two sections to a maximum of $7 \mathrm{mM}$ at $52.9 \mathrm{mbsf}$ before decreasing to relatively constant values of $5.4 \mathrm{mM}$ from $72.7 \mathrm{mbsf}$ to the deepest sample at 195 mbsf. $\mathrm{pH}$ values are more variable (8.0-7.1) than those observed in Hole U1394B, but no consistent pattern is observable in the data, suggesting there may be some analytical artifacts in the data. Ammonium concentrations increased from $0.1 \mathrm{mM}$ in the uppermost sample to $1.1 \mathrm{mM}$ at $72.7 \mathrm{mbsf}$ and only increased gradually to $1.2 \mathrm{mM}$ at $185 \mathrm{mbsf}$. These values are lower than those observed in Hole U1394B and are consistent with the greater water depth of Site U1395, which results in greater oxidation of the organic matter before it reaches the seafloor. Calcium concentrations are only slightly lower than bottom water values in samples from the uppermost $106 \mathrm{~m}$ of the hole but show an increase to higher values toward the deepest sample (195 mbsf) (Fig. F9). In contrast, magnesium concentrations show a distinct decrease at the same depth interval. This simultaneous increase in calcium and decrease in magnesium is typical for pore water influenced by water-rock interaction processes with basaltic glass. Hence, it is possible that the covariation 
in calcium and magnesium concentrations in the deeper section of Hole U1395B may reflect a higher basaltic component in the volcanogenic material at this horizon. Potassium concentrations decrease with depth, consistent with the reaction of pore water with volcanic material. Total sulfur concentrations are slightly depleted relative to seawater and show no consistent trend with depth. Chloride concentrations fluctuate within the normal range (550$570 \mathrm{mM}$ ) expected for pore water obtained from squeezing carbonate sediment.

\section{Site U1396}

\section{Background and objectives}

IODP Site U1396 (proposed Site CARI-01C; $16^{\circ} 30.49^{\prime} \mathrm{N}, 62^{\circ} 27.10^{\prime} \mathrm{W} ; 801 \mathrm{mbsl}$ ) is the most western site drilled during Expedition 340 (Fig. F3; Table T1).

The bathymetric survey for Site U1396 revealed a region bounded by a topographic high to the north and by two large canyons to the south. Site survey data indicated that this site could penetrate regular (unperturbed) seismic reflectors. The drill site is located on the topographic high to minimize any perturbations (e.g., related to turbidites). Site U1396 is located in the same area as the $5.75 \mathrm{~m}$ long CARMON 2 core taken during the Caraval cruise in 2002. Sediment recovered in the CAR-MON 2 core provides a stratigraphic record extending back 250 k.y., as shown by $\delta^{18} \mathrm{O}$ chronostratigraphy. The calculated sedimentation rate (including tephra) is $\sim 2.3 \mathrm{~cm} / \mathrm{k} . \mathrm{y}$. (Le Friant et al., 2008). The recovered core also contained material from several explosive Plinian eruptions, which had not previously been identified on land (Le Friant et al., 2008).

The objective for Site U1396 was to characterize the eruptive history of Montserrat. Volcanism started on Montserrat at $\sim 2.6 \mathrm{Ma}$ at Silver Hills and moved to Centre Hills between 0.5 and $1.0 \mathrm{Ma}$, with the youngest volcanism being centered on the Soufrière Hills-South Soufrière Hills complex ( 170 ka to present) (Harford et al., 2002). With conventional coring it is only possible to retrieve samples of recent volcanic activity. Drilling to a target depth of 132 meters below seafloor (mbsf) at Site U1396 was intended to extend our knowledge of the volcanic history of Montserrat to the birth of the island at at least 2.5 Ma. Petrologic, lithologic, sedimentologic, and geochronologic analyses of volcanic rocks and volcaniclastic material from this site are expected to date as far back as $4 \mathrm{Ma}$ (assuming a sedimentation rate of $2.3 \mathrm{~cm} / \mathrm{k} . \mathrm{y}$. from the CAR-MON 2 study) and will provide significant new constraints on the early development of volcanism on Montserrat and on the spatial and temporal distribution of volcanic activity.

\section{Scientific results}

\section{Lithostratigraphy}

Deposits cored at Site U1396 mainly comprise a series of hemipelagic sediment, tephra layers, and volcaniclastic sand (Fig. F10). Even though the nature of the cored material at this site makes division into lithostratigraphic units more difficult, five different lithostratigraphic units (Units A-E) were identified. Unit A consists of a $\sim 40 \mathrm{~cm}$ thick sequence of bioclast-rich fine sand with high water content. The sand is massive and ungraded and probably represents a high-density turbidite. Unit B ( 116 m thick) comprises mainly a sequence of tephra layers $(\sim 35$ layers of varying thickness, more abundant below 90-95 mbsf) intercalated in the hemipelagic background sedimentation. Hemipelagic sediment dominates the middle part of this unit. However, there may be many more layers of cryptotephras (not identifiable by standard visual core description methods) embedded in the hemipelagic mud. The tephra layers vary in thickness (mostly $<5 \mathrm{~cm}$; a few $>10 \mathrm{~cm}$ ) and are generally normally graded. The upper and lower layers of this unit contain a poorly sorted, massive, medium sand-sized mixture of bioclastic and volcaniclastic particles; the two occurrences of this mixture are interpreted as turbidite sequences. Isolated pebble-sized volcanic clasts are observed in the hemipelagic mud at a few locations. Unit $\mathrm{C}$ is $\sim 6 \mathrm{~m}$ and consists of massive mediumcoarse volcaniclastic sand that is mainly andesitic in composition (85\%) within a finer matrix consisting of mineral particles. Unit D (122.0-123.9 mbsf) comprises a distinctive sequence of unusually coarse (commonly up to centimeter-scale clasts) pinkish breccias. This unit is composed of five fining-upward units with well-sorted intervals of pebble-sized clasts (as large as $2 \mathrm{~cm}$ ), with little or no sand or mud-sized matrix material. Massive layers of fine sand or silt (1$5 \mathrm{~cm}$ thick) separate these normally graded intervals. Unit $\mathrm{E}(\sim 16 \mathrm{~m}$ thick) also consists of a series of mainly well sorted tephra layers intercalated with the hemipelagic background sediment.

Thirty samples were taken to define the mineralogical composition and carbonate content of the cored material. Even though the number of tephra layers sampled at this site is high, no purely volcanic samples were obtained. In contrast to previous sites, high Mg-calcite is only present in one section (340U1396C-6H-2). All other carbonate-rich layers contain pure calcite and aragonite in variable proportions, with calcite generally dominating the assemblage. Clay minerals are ubiquitous at this site, with smectite and kaolinite present in all samples and glauconite commonly identified. Halloysite may be present in some samples, but the spectra are not clear enough to be certain. A large bulge beneath the main 
peaks in some of the volcanic-rich samples suggests that significant amounts of volcanic glass are present in some of the tephra layers. $\mathrm{CaCO}_{3}$ and organic carbon abundances indicate that the retrieved sediment is largely a mixture of carbonate-rich hemipelagic sediment with carbonate and low organic carbon volcanogenic material delivered by volcanic fallouts. The highest observed $\mathrm{CaCO}_{3}$ concentration is $72 \%$, with most samples much lower, suggesting that volcanic material is dispersed throughout the cores even though it is not necessarily visible to the naked eye.

\section{Paleontology and biostratigraphy}

Based on the biostratigraphic studies done on Site U1396 calcareous nannofossil and planktonic foraminiferal datums, the cored material could be assigned a late Pleistocene to early Pliocene age. Nannofossil preservation was generally good to moderate in the core catcher samples analyzed at this site. Samples obtained from $\sim 6$ to $\sim 35$ mbsf yielded a nannofossil assemblage typical for the Pleistocene with, for example, small Gephyrocapsa sp., Helicosphaera hyalina, Pseudoemiliania lacunosa, Gephyrocapsa caribbeanica, and Crenalithus doronicoides. The interval between $\sim 44$ and $\sim 54$ mbsf yielded a characteristic late Pliocene assemblage with abundant Discoaster brouweri and common Calcidiscus macintyrei in addition to Discoaster surculus and Hayaster perplexus. Between $\sim 64$ and $~ 91$ mbsf the observed assemblages are characteristic for the early Pliocene with a variety of Discoaster species, such as Discoaster pentaradiatus, $D$. surculus, D. brouweri, Discoaster asymmetricus, Discoaster tamalis, Discoaster variabilis, and Discoaster challengeri. From $\sim 100$ mbsf to the bottom of the site, the retrieved samples contained Sphenolithus abies/neoabies and Reticulofenestra pseudoumbilica, which are indicative of the early Pliocene Zone CN11, Subzone CN11a S. neoabies.

Every planktonic foraminiferal biozone (PT1b, PT1a, PL6, PL5, PL4, PL3, PL2, and PL1) from Quaternary to the early Pliocene was recorded in the material deposited at Site U1396, and many different datums were observed over this $135 \mathrm{~m}$ interval: Globorotalia flexuosa (0.07-0.40 Ma), Globorotalia tosaensis (T $0.61 \mathrm{Ma}$ ), Globorotalia exilis (T $2.1 \mathrm{Ma})$, Globigerinoides extremus (T $2.1 \mathrm{Ma})$, Globorotalia miocenica (T $2.39 \mathrm{Ma}$ ), Globorotalia pertenuis (T $2.60 \mathrm{Ma}$ ), Globorotalia multicamerata (T $2.99 \mathrm{Ma})$, Sphaeroidinellopsis seminulina (T $3.16 \mathrm{Ma}$ ), Pulleniatina primalis (T $3.65 \mathrm{Ma}$ ), Globorotalia margaritae (T $3.84 \mathrm{Ma}$ ), and Globigerina nepenthes (T $4.36 \mathrm{Ma}$ ). Though several more first appearance datums are calibrated through this interval as secondary datums, when compared against the datums listed above they appeared to be largely unreliable as age determinations at this site, likely due to regional differences, and so were not used.

\section{Paleomagnetism}

The magnetostratigraphic record obtained from the material cored at Site U1396 is in excellent accordance with biostratigraphic observations. The FlexIt orientation tool was deployed with all cores from Holes U1396B and U1396C and 12 of the 15 cores from Hole U1396A. Declination can therefore be corrected to true north for most of the site. The recorded declination data show sixteen $180^{\circ}$ shifts in declination in the longer U1396C record and fifteen in U1396A (Fig. F10). Using the geomagnetic polarity timescale (GPTS) of Cande and Kent (1995), nine periods of normal polarity and nine periods of reversed polarity can be identified for this site. The earliest polarity reversal we see in Hole U1396A is the beginning of Chron C3n.1n (4.29 Ma) at $129.4 \mathrm{mbsf}$, giving this hole a basal age of 4.29-4.48 Ma. The longer Hole U1396C record contains the end of Chron C3n.2n at $4.48 \mathrm{Ma}$, giving this hole a basal age of 4.48-4.62 Ma. Using a linear approach in conjunction with the depths of the dated reversals, an age-depth model indicates an average sedimentation rate at Site U1396 of $\sim 3.1 \mathrm{~cm} / \mathrm{k} . \mathrm{y}$. However, sedimentation rates vary over the observed depth interval cored at this site. Pliocene sedimentation rates are on the order of $4 \mathrm{~cm} / \mathrm{k} . \mathrm{y}$., whereas Pleistocene rates are $\sim 1.7 \mathrm{~cm} / \mathrm{k} . \mathrm{y}$. and rates from the base of the core to the beginning of the Gauss Chron $(3.58 \mathrm{Ma})$ are $\sim 5.3 \mathrm{~cm} / \mathrm{k} . \mathrm{y}$. Normalization of the NRM by magnetic susceptibility indicates good potential for construction of a relative paleointensity record for Site U1396, which should allow for greater constraint of ages in between the GPTS defined reversal horizons.

\section{Physical properties}

Physical properties data obtained for Site U1396 reflect the different material recovered relatively well (Fig. F10). Magnetic susceptibility usually increases in areas where volcanic material was recovered, whereas NGR decreases. Bulk density obtained from whole cores shows no systematic trend with depth or changes in lithology. The same is true for measured $P$-wave velocities on the whole cores. Discrete measurements of $P$-wave velocity show higher velocities for the volcanic layers (1650 to $>1800 \mathrm{~m} / \mathrm{s}$ ) than for the hemipelagic background sediment (1550-1650 m/s). Shear strength measurements show a clear linear trend that increases with depth. Within this linear trend, there are a few anomalously low values at 85,115 , and 130 mbsf. Porosity data obtained from discrete measurements range from $54 \%$ to $70 \%$ and show no clear depth trend. Because normally compacted sands do not typically have porosities $>50 \%$, we suggest that the anomalously high porosities we observe in sandy sediments at Site U1396 may result from reworking of the sediment during core recovery and splitting. Bulk density values obtained from discrete 
samples range from 1.45 to $2.00 \mathrm{~g} / \mathrm{cm}^{3}$; grain density ranges between 2.65 and $2.80 \mathrm{~g} / \mathrm{cm}^{3}$. Formation temperature was measured at 24.6, 34.1, 43.6, and $53.1 \mathrm{mbsf}$ in Hole U1396A and at 55.9 and $103.4 \mathrm{mbsf}$ in Hole U1396C. The temperature gradient is $69.3^{\circ} \pm$ $1.5^{\circ} \mathrm{C} / \mathrm{km}$ and, using the measured thermal conductivity of $1.04 \mathrm{~W} /(\mathrm{m} \cdot \mathrm{K})$, with a standard error on the mean of $0.01 \mathrm{~W} /(\mathrm{m} \cdot \mathrm{K})$, the implied conductive heat flow is $72 \pm 2 \mathrm{~mW} / \mathrm{m}^{2}$. Because this site sits on a submarine ridge, this heat flow underestimates a conductive heat flow by $2 \%$; sedimentation has a negligible effect on heat flow (Manga et al., 2012).

\section{Geochemistry}

Pore water from the hemipelagic sediment was analyzed, as well as headspace gases. Samples for headspace analyses were taken at 15 depths throughout Hole U1396A. The uppermost sample (from Section 340-U1396A-1H-3) had a methane concentration of $3.6 \mathrm{ppm}$, but all other samples had levels between 2.1 and $2.6 \mathrm{ppm}$. No higher hydrocarbons were detected. Samples for pore water extraction were taken from every core in Hole U1396C. Alkalinity values are generally low $(<1.5 \mathrm{mM})$ throughout the hole. $\mathrm{pH}$ values are generally lower (7.6-7.1) than those at Sites U1394 and U1395, but no consistent pattern is observable in the data. Ammonium concentrations are much lower than at the previous two sites. These two observations may be related to the fact that Site U1396 is located at shallow water depths on a basement high with strong bottom currents. This effect tends to winnow out the finer grained, more reactive organic matter and leads to less intense organic carbon-driven diagenesis. Alternatively, the results may suggest removal of these pore fluid components through precipitation and ion exchange reactions. Calcium concentrations are consistently higher than bottom water values in samples from throughout the hole, and magnesium concentrations are consistently lower than seawater concentrations (Fig. F10). These features are commonly seen in deep sediment pore water as a result of alteration of basaltic glass and suggest that many of the tephra layers observed in the core may have a basaltic composition. This hypothesis is supported by potassium concentrations, which are also lower than seawater. Overall, $\Sigma \mathrm{S}$ concentrations are slightly depleted relative to seawater but do not show a consistent trend with depth. Chloride concentrations fluctuate within the normal range (550-570 $\mathrm{mM}$ ) expected for pore water obtained from squeezing carbonate-rich sediment.

\section{Site U1397}

\section{Background and objectives}

IODP Site U1397 (proposed Site CARI-10B; $14^{\circ} 54.41^{\prime} \mathrm{N}, 61^{\circ} 25.35^{\prime} \mathrm{W} ; 2482 \mathrm{mbsl}$ ) is located west of Martinique (Fig. F11; Table T1). The bathymetric survey for Site U1397 revealed a region with a topographic high bound by large canyons. Site survey seismic data indicated that this site could, in the upper part, penetrate regular (unperturbed) sedimentary reflectors, whereas in the lower part some chaotic reflectors are visible. The drill site is located on the topographic high to try to avoid perturbations. Site U1397 is located very close to Core CAR-MAR 4 (7 m long) taken during the Caraval cruise in 2002. The CAR-MAR 4 core provides a sedimentary record that extends to $\sim 32 \mathrm{ka}$, as determined by $\delta^{18} \mathrm{O}$ chronostratigraphy. The sedimentation rate (including tephra) is $\sim 20 \mathrm{~cm} / \mathrm{k} . y$. (Boudon et al., submitted). Correlating the tephra sampled in the core to onshore deposits of the Montagne Pelée Volcano shows that a significantly greater number of tephra layers are deposited in the marine environment than have been identified during onshore studies (e.g., 25 tephra layers were identified in the core between 5 and $15 \mathrm{ka}$, whereas only 10 magmatic events were previously recognized in onshore studies).

The objective for Site U1397 was to characterize the eruptive history of Martinique and the chaotic units appearing in the seismic profiles of this site. The cores retrieved will significantly improve our understanding of the eruptive history of Martinique in space and time, as we plan to sample material reaching back $>1$ m.y. (assuming a sedimentation rate of $20 \mathrm{~cm} / \mathrm{k} . \mathrm{y}$. and a total target depth of $314 \mathrm{mbsf}$ ). We expect to identify and date layers related to the Montagne Pelée and Pitons du Carbet Volcanoes and to sample the region related to the transition of volcanism from the Pitons du Carbet and Mont Conil Volcanoes to the Montagne Pelée Volcano. The end of volcanic activity at the Pitons du Carbet and Mont Conil Volcanoes ( 0.3-0.5 Ma) precedes the beginning of the Montagne Pelée activity. We want to test the hypothesis that more mafic and denser magma was erupted for a period of several thousand years following edifice collapse until a new lava cone reached sufficient volume to erupt more evolved lavas (Pinel and Jaupart, 2000; Boudon et al., 2007). This site could also contain tephra from Dominica volcanoes, which will be distinguished on the basis of geochemistry and microtextural characteristics (Machault, 2008). Volcanism on Dominica has been dominated by andesitic to dacitic eruption products since the Pleistocene (Lindsay et al., 2005c).

\section{Scientific results}

\section{Lithostratigraphy}

A continuous stratigraphic record was only retrieved for the uppermost $120 \mathrm{~m}$ at this site because of generally poor recovery below this depth (Figs. F12, F13). Sediment retrieved at this site was divided into 
eight lithostratigraphic units (Units A-H). Similar to the other sites, each unit consists of various combinations of hemipelagic mud, volcaniclastic or mixed (volcaniclastic-bioclastic) turbidites, and various tephra layers. Generally, unit boundaries and the material cored are similar in both holes, except that a higher proportion of turbidites and a lower proportion of tephra are observed in some units in Hole U1397B compared to those in Hole U1397A. It is likely that most of the missing tephras were eroded during the emplacement of turbidites. Boundaries for each of the lithostratigraphic units are defined by abrupt or gradational changes in the abundance of lithologies, distinctive marker horizons, different mineralogical compositions of tephra, and/or unusually thick turbidites. Unit A (0-28 mbsf in Hole U1397A and 0-26 mbsf in Hole U1397B) is composed of a thick sequence of hemipelagic sediment with interbedded tephra and volcaniclastic layers. The tephra layers, of which there are at least 200 , are well sorted and either massive or normally graded. The few turbidites observed in this unit are poorly sorted. Unit B (28-53 mbsf in Hole U1397A and 26-53 mbsf in Hole U1397B) is composed of tephra layers and volcaniclastic turbidites intercalated in hemipelagic mud. The proportion of turbidites is higher than that found in Unit A. Turbidites are normally graded and contain variable amounts of fresh pumice. The matrix of the turbidites is mainly composed of crystals and very low proportions of carbonates and lava clasts. Most of the tephra layers are dark and fine grained and are frequently normally graded. Unit $\mathrm{C}$ (53-77 mbsf in Hole U1397A and 53-78 mbsf in Hole U1397B) is divided into two subunits (C-1 and $\mathrm{C}-2$ ). Subunit C-1 is dominated by thick turbidite sequences of mixed (bioclastic-volcaniclastic) composition. Crystals, massive lava fragments, and pumice particles (sometimes in higher proportions) make up the volcanic component of these turbidites. Hemipelagic mud is frequently absent between turbidite layers. Subunit C-2 ( $<3 \mathrm{~m}$ thick) comprises a debris flow deposit and a section of deformed sediment. The debris flow deposit consists of very abundant deformed mud clasts and large fragments of hydrothermally altered and fresh andesitic lava. Unit D (77-91 mbsf in Hole U1397A and 78-95 mbsf in Hole U1397B) is composed of a series of volcaniclastic turbidites and a few tephra layers, which are interbedded in a hemipelagic mud. The proportion of hemipelagic sediment is very low in this unit, attesting to the erosional character of the turbidites. Unit E (91-120 mbsf in Hole U1397A and 95-150 mbsf in Hole U1397B) is composed of a series of thick massive to normally graded volcaniclastic turbidites containing a large amount of massive to poorly vesiculated lava fragments. The base of this unit is not observed, and below this unit the stratigraphy is more uncertain, as core recovery was very low. Unit F (150-168 mbsf in Hole U1397A and 150-160 mbsf in Hole U1397B) is divided into two subunits on the basis of the compaction of the sediment. Subunit F-1 is composed of a package of hemipelagic mud with a few interbedded tephra layers, whereas Subunit F-2 is composed of the same sequence of sediment, weakly compacted at the top and showing progressive lithification into mudstones toward the base. Unit G (168-230 mbsf in Hole U1397A and 160-247.5 mbsf, the bottom of Hole U1397B) is composed of mud-rich sandstone layers and semiconsolidated, highly fractured, and contorted mudstones. It contains abundant lava clasts, few pebbles, and a larger block composed of andesitic lava containing large phenocrysts of amphibole and quartz. Similar lava is generated by the Pitons du Carbet Volcano, south of Montagne Pelée, and is unique to the area of Martinique and Dominica. The period of activity that generated this type of magma is dated at $\sim 330-350 \mathrm{ka}$ (Germa et al., 2011; Samper et al., 2008). Unit H (230-259.6 mbsf) is only represented in Hole U1397A. Unit H consists of heavily bioturbated hemipelagic mud. A few layers of bioclastic sandstone are interbedded within the mudstone.

Forty-four samples were taken to characterize the mineralogy of the volcanic material cored and the carbonate content. The volcanic material retrieved contains mainly plagioclase, hornblende, quartz, and amphibole. Hornblende appears to be more alkali rich than observed in samples from around Montserrat. Clay minerals are ubiquitous throughout the hole and are also more abundant than in samples from the Montserrat sites. The dominant clay minerals are smectite, kaolinite, and glauconite. At the base of Hole U1397A, the abundance of clay minerals (mainly smectite) is especially high, and dolomite is also present in significant quantities, possibly reflecting the presence of hydrothermal alteration products. $\mathrm{CaCO}_{3}$ concentrations are lower than those found in the sites around Montserrat, and the main carbonate minerals identified are calcite with minor aragonite. This combination likely reflects the greater water depth at this location and the absence of any significant aragonite preservation.

\section{Paleontology and biostratigraphy}

The nanno- and microfossil content of the sediment described above are persistently reworked, and many samples contain poorly preserved shallow-water reef benthic foraminifers and coral fragments. Generally, the sediment contained low abundances of calcareous nannofossils and planktonic and benthic foraminifers with varying levels of preservation. Where obtained, 
biostratigraphic dates were generally nonsequential; however, an overall trend to older material with increasing depth is observed. Calcareous nannofossils and planktonic foraminifers show that Site U1397 contains many levels of reworked sediment from the upper Miocene to upper Pliocene amidst a background of upper Pleistocene sedimentation. Overall, only a few datum species (Globigerinella calida, Globorotalia flexuosa, and Emiliania huxleyi) could be used as an age constraint for the cored material. The resulting age model resolves an age younger than $220 \mathrm{ka}$ for the top $\sim 25 \mathrm{mbsf}$, younger than $250 \mathrm{ka}$ from $\sim 50$ to $\sim 100 \mathrm{mbsf}$, younger than $\sim 350 \mathrm{ka}$ from 100 mbsf to nearly the base, and $\sim 400 \mathrm{ka}$ at the bottom of this site. It should be noted that these ages are only a maximum age estimate and that any constraint on the youngest material is inappropriate given the extensive reworking of sediment.

\section{Paleomagnetism}

Generally, the retrieval of a magnetostratigraphic record for this site was as complicated as the retrieval of a biostratigraphic record because of the nature of the cored material and recovery. Using the detailed core description logs, only data measured on identifiable hemipelagic sediment layers were used for interpretation. These layers were highly discontinuous at Site U1397, particularly below $\sim 55 \mathrm{mbsf}$. Shallower than $\sim 55$ mbsf, inclination values obtained on discrete samples show scattered but positive inclination, clustering around the expected GAD inclination. Declination shows little variation, suggesting that all sediment and tephra to a depth $\sim 55$ mbsf was deposited in the Brunhes Chron ( $<780 \mathrm{ka})$. Below this depth the record becomes increasingly discontinuous, making confident interpretation of ages based solely on paleomagnetic data difficult.

\section{Physical properties}

The physical properties of the material retrieved at Site U1397 can generally be correlated to the lithologic variations observed throughout the cored material (Figs. F12, F13). Bioclastic and volcaniclastic turbidites and thick tephra layers can be distinguished from background sedimentation (hemipelagic mud) by most of the physical proprieties. Magnetic susceptibility data show large variations, with maximum values $\left(6880 \times 10^{-5} \mathrm{SI}\right)$ more than twice as high as those obtained from measurements at the other sites. Peaks in magnetic susceptibility values correlate with tephra layers and volcaniclastic turbidites. Measured bulk densities increase slightly with depth, whereas NGR data show no consistent downhole trend. $P$-wave velocity ranges between 1400 and $1750 \mathrm{~m} / \mathrm{s}$ with no significant downhole increase. All three of these properties have a sharp boundary at depths that correspond to the base of turbidites. The shear strength of the cored sediment increases with depth $(1 \mathrm{kPa} / \mathrm{m})$ for the uppermost $\sim 55 \mathrm{mbsf}$ at Site U1397. No shear strength measurements could be performed in the interval between $\sim 55$ and $65 \mathrm{mbsf}$ because of the coarse nature of the retrieved sediment (mainly sand). Between 65 and 80 mbsf, shear strength increases as high as $200 \mathrm{kPa}$; it then decreases from 80 to 95 mbsf. The interval between 95 and 150 mbsf was again not favorable to measure shear strength. Between 150 and 180 mbsf shear strength is quite variable, with values ranging from $<50$ to $>450 \mathrm{kPa}$, reflecting the variable nature of the sampled sediment and likely variable consolidation states. Porosity data show, as was observed at Site U1396, no consistent trend with depth. Porosity ranges from $\sim 40 \%$ to $68 \%$. Bulk density ranges from 1.55 to $2.40 \mathrm{~g} / \mathrm{cm}^{3}$ and shows a clear negative correlation with porosity. The dark-colored volcaniclastic turbidites have systematically higher bulk densities $\left(1.75-2.40 \mathrm{~g} / \mathrm{cm}^{3}\right)$ than the other retrieved sediment. Grain density ranges between 2.48 and $3.17 \mathrm{~g} / \mathrm{cm}^{3}$, with hemipelagic sediment showing grain densities between 2.6 and $2.85 \mathrm{~g} / \mathrm{cm}^{3}$. Formation temperature was measured using the APCT-3 at 36.5, 46.0, and 55.5 mbsf in Hole U1397A and 25.6, 35.1, and $61.3 \mathrm{mbsf}$ in Hole U1397B. The temperature gradient is $70.0^{\circ} \pm 8.8^{\circ} \mathrm{C} / \mathrm{km}$. Using the thermal conductivity of $1.028 \mathrm{~W} /(\mathrm{m} \cdot \mathrm{K})$, with standard error on the mean of $0.022 \mathrm{~W} /(\mathrm{m} \cdot \mathrm{K})$, the implied conductive heat flow is $72 \pm 9 \mathrm{~mW} / \mathrm{m}^{2}$. The bathymetry of this site lowers the near-surface (measured) heat flow by $4 \%$, and the high sedimentation rate of this site can lead to heat flow being underestimated by as much as $4 \%$ (Manga et al., 2012).

\section{Downhole logging}

In situ measurements of geophysical properties obtained by downhole logging in Hole U1397B should be treated with caution because of the large diameter of the borehole. An oversized borehole such as Hole U1397B can make centralization and eccentralization of the tools in the borehole difficult, with gamma ray and FMS measurements being the most significantly affected. Measurements of electrical resistivity, magnetic susceptibility, and $P$-wave velocity are less affected, and general trends and relative changes displayed by those measurements should be reliable.

Four logging units were identified based on specific characteristics observed across the physical properties measured. Logging Unit 1 (85-90 mbsf) is characterized by relatively consistent values of resistivity and gamma radiation and average values of $P$-wave 
velocity $(\sim 1650 \mathrm{~m} / \mathrm{s})$. Magnetic susceptibility decreases with depth. Logging Unit 2 (90-127 mbsf) is characterized by four intervals that exhibit increasing resistivity and $P$-wave velocity with depth. The boundaries of these intervals are marked by distinct changes in magnetic susceptibility (local peaks superimposed on the general decreasing trend with depth). Logging Unit 3 (127-185 mbsf) shows a return to less variable resistivity and $P$-wave velocity values. This logging unit is divided into two subunits (logging Subunits 3A and 3B) based on subtle changes in the character of the recorded geophysical properties, of which magnetic susceptibility is the most distinctive. The amplitude of magnetic susceptibility variations is much higher in logging Subunit 3A than in logging Subunit 3B. In addition, $P$-wave velocity is slightly higher in logging Subunit 3B (average $=\sim 1760 \mathrm{~m} / \mathrm{s}$ ) than in logging Subunit 3A (average $=\sim 1710 \mathrm{~m} / \mathrm{s})$. Logging Unit $4(185 \mathrm{mbsf}$ to base of the hole) is characterized by higher values of resistivity and magnetic susceptibility than those found in logging Unit 3 . $P$-wave velocity is also higher in this unit (average $=\sim 1900 \mathrm{~m} / \mathrm{s}$ ), completing the downhole trend of increasing $P$-wave velocity.

\section{Geochemistry}

Samples for headspace gas analysis were taken from 18 depths throughout Hole U1397A. Samples from the uppermost $76 \mathrm{~m}$ tend to have slightly higher methane concentrations (3.1-4.4 ppm) than those from 94 to 266 mbsf (2.3-3.7 ppm). No higher hydrocarbons were detected. Pore water alkalinity values increase with depth in the upper part of the sediment at this site and reach a maximum of $5.1 \mathrm{mM}$ between 23 and 46 mbsf before decreasing to $3.9 \mathrm{mM}$ in the deepest samples (164-182 mbsf). pH values vary between 7.3 and 8.2 , but no consistent pattern is observable in the data. Ammonium concentrations are lower than those at comparable sites around Montserrat (Sites U1394 and U1395); the lower concentrations likely reflect the greater water depth of this site. The shape of the ammonium profile is similar to that of the alkalinity profile, suggesting that diagenetic processes in the sediment column dominate both. Calcium concentrations decrease from the seawater value to $9.1 \mathrm{mM}$ at 23 mbsf and then increase to $11.0 \mathrm{mM}$ in the deepest sample (182 mbsf) (Fig. F13). Magnesium concentrations (which scatter around values slightly higher than seawater) and potassium concentrations (which are higher in the uppermost 75 mbsf and show a weak trend to lower values between 164 and $182 \mathrm{mbsf}$ ) suggest that alteration of volcanic matter does not play a dominant role in defining major element pore water concentrations. $\Sigma S$ concentrations decrease from the seawater value to $26 \mathrm{mM}$ at $43 \mathrm{mbsf}$ and then increase to near seawater concentrations in the deepest samples. Chloride concentrations are within the normal range (560-570 mM) expected for pore water obtained from squeezing carbonate-rich sediment.

\section{Site U1398}

\section{Background and objectives}

IODP Site U1398 (proposed Site CARI-09B; $\left.14^{\circ} 16.70^{\prime} \mathrm{N}, 61^{\circ} 53.34^{\prime} \mathrm{W} ; 2935 \mathrm{mbsl}\right)$ is located west of Martinique (Fig. F3; Table T1). The objective for this site was to characterize the sedimentation processes in the backarc Grenada Basin. We planned to drill through hemipelagic sediment and turbidites and retrieve a complete sedimentation record to $\sim 264$ mbsf. Site survey data showed that we could penetrate sedimentary reflectors indicative of the deposition of hemipelagic sediment and turbidites. With the recovered material we hope to identify the turbidites related primarily to debris avalanche deposition. One focus is to evaluate whether submarine debris avalanches can generate voluminous turbidites long after their emplacement and, if so, how far such turbidites can travel. We also expect to improve the reconstruction of the postcollapse eruptive activity of Pitons du Carbet (Boudon et al., 2007). This will provide better constraints on the transition of activity between the Pitons du Carbet and Montagne Pelée Volcanoes. Finally, we expect to sample turbidites with volcanic material coming from Dominica (e.g., Roseau tuff).

\section{Scientific results}

\section{Lithostratigraphy}

Generally, the upper parts of both holes at this site are dominated by volcaniclastic turbidites, whereas the lower portions are composed of various combinations of hemipelagic sediment with intercalated volcaniclastic turbidites and tephra (Figs. F14, F15). The retrieved sediment was divided into seven lithostratigraphic units (Units A-G). The uppermost $70 \mathrm{~cm}$ of Unit A (0 to $\sim 40 \mathrm{mbsf}$ ) is composed of hemipelagic mud; below this depth Unit A is composed of a series of thick volcaniclastic turbidites, consisting of massive, normally graded sand-sized minerals, lava particles, and detrital carbonates interrupted by thin layers of hemipelagic mud. Abundant pumice clasts are common throughout the entire unit. The upper part of Unit B ( 40 to $\sim 57$ mbsf) consists of hemipelagic sediment with interbedded thin tephra layers, whereas the lower part is composed of a succession of massive normally graded turbidite sequences, which can be as thick as $6 \mathrm{~m}$. Turbidites occasionally display compositional laminations, grain-size layering, and parallel stratification in the upper part of each layer. Unit $\mathrm{C}(\sim 57$ to $\sim 80 \mathrm{mbsf})$ consists of hemipelagic 
mud interbedded with multiple thin tephra layers and thin turbidites. The turbiditic sequences, exhibiting mainly normal grading, generally contain pumice clasts and hemipelagic clay. Unit D ( $80-104$ mbsf in Hole U1398A and $~ 80-99$ mbsf in Hole U1398B) is composed of a succession of massive turbidites that are a few meters thick. The turbidites, often displaying normal grading, are separated by hemipelagic sediment interbedded with thin tephra layers. The upper of two distinctive pink-colored ash layers forms the lower boundary of Unit D. Unit E (104-115 mbsf in Hole U1398A and 99-115 mbsf in Hole U1398B) is characterized by multiple tephra layers. It also contains a few turbidites that are generally $<1 \mathrm{~m}$ thick, interbedded with hemipelagic sediment. Two pinkish, $1 \mathrm{~cm}$ thick glassy ash layers are present in the upper half of Unit E. The top of Unit F (115-171 mbsf), only fully recovered in Hole U1398B, is composed of a $3 \mathrm{~m}$ thick debrite followed by a succession of thick massive turbidites. Below the sequence of massive turbidites, Unit F comprises a sequence of intercalated multiple thin tephra layers and small-scale turbidites. Unit G (171-260.5 mbsf in Hole U1398A and 171254.8 mbsf in Hole U1398B) mostly comprises welllithified, heavily bioturbated hemipelagic mud. This unit occasionally contains interbedded volcaniclastic sand layers. A whitish to pinkish colored, $1 \mathrm{~cm}$ thick glassy ash layer occurs at 232 mbsf in Hole U1398A and 246 mbsf in Hole U1398B.

XRD data obtained from discrete samples throughout the cores show that quartz and plagioclase minerals dominate the volcanic material, whereas the marine sediment is dominated by calcite and lesser amounts of aragonite. Amphibole is less frequently present than in the cores obtained from previous sites. Smectite, kaolinite, and, to a lesser extent, glauconite are also ubiquitous. Clay abundance increases with depth. Pyrite has often been observed in the cored material that is rich in volcanic particles but could not be identified by XRD. Calcium carbonate concentrations are highly variable and are generally lower in intervals with higher proportions of volcanic material. Maximum concentrations are $~ 35 \%$, reflecting the greater proportion of terrestrial clay minerals and possibly the absence of significant aragonite preservation.

\section{Paleontology and biostratigraphy}

Using calcareous nannofossil as well as planktonic foraminiferal datums, the cored material could be assigned to the upper Pleistocene, indicating extremely high sedimentation rates. However, as observed in the cored material of previous sites, reworking of much older (early Pleistocene and late Pliocene) material is evident in several of the studied samples. This is consistent with the shallow-water benthic foraminifers, fragments of shells and corals, pteropods, heteropods shells, otoliths, and sponge spicules (Demospongiae) observed throughout the many of the samples examined. The nannofossil species observed at this site (typically prevalent: Emiliania huxleyi, Gephyrocapsa oceanica, Gephyrocapsa caribbeanica, Gephyrocapsa parallela, Ceratolithus cristatus, and Ceratolithus telesmus) are characteristic of upper Pleistocene sediment. Thus, the entire sequence was placed in Zone CN15, E. huxleyi, which has a maximum age of $0.25 \mathrm{Ma}$. The presence of Miocene to Pliocene nannofossil species throughout much of the sampled sediment indicates extensive reworking of the sediment retrieved at this site. Planktonic foraminifers were present in all samples, although some were found at very low abundances, possibly because of the high volume of volcanic material. In samples with abundant specimens, the assemblage of planktonic foraminifers was diverse but dominated by Globigerinoides ruber (white and pink), Globigerinoides sacculifer, and Neogloboquadrina dutertrei (dextral). Other abundant species include Globorotalia truncatulinoides and Globorotalia tumida. The fauna does not change significantly throughout the section recovered at Site U1398, and all species present are indicative of warm subtropical waters. The presence of Globigerinella calida (B $0.22 \mathrm{Ma}$ ) at the base of this site dates the sediment to younger than 0.22 Ma, within the Pleistocene. Marker species characteristic of early Pleistocene and late Pliocene ages were also found, but they simply reinforce the reworked nature of the deposited sediment. Based on the occurrence of Cibicides wuellerstorfi and Pyrgo murrhina, a bathyal paleodepth was interpreted.

\section{Paleomagnetism}

Generally, the magnetostratigraphic record obtained from the cored material is in accordance with biostratigraphic observations, despite creation of the stratigraphic record being complicated by discontinuous retrieval of hemipelagic sediment throughout the holes at Site U1398. Between 0 and $~ 170$ mbsf at this site, all inclination data show scattered but positive inclination, clustering around the expected inclination as predicted by a GAD $\left( \pm 27^{\circ}\right)$. Declination agrees, showing little variation, and suggests that sediment shallower than 170 mbsf was deposited within the Brunhes Chron and is younger than $780 \mathrm{ka}$ (Cande and Kent, 1995). Recovery of sediment deeper than 170 mbsf using the XCB resulted in core rotation and magnetic overprinting, restricting polarity interpretation to discrete measurements of inclination at roughly $10 \mathrm{~m}$ intervals. Inclinations are generally shallower than would be expected based on the GAD at this location; however, without declination data to reinforce these shallow inclination data, interpretation of polarity is difficult. Some 
sections of the core show evidence for postdepositional deformation; however, this evidence cannot account for all the observed negative inclination intervals. If these consistently negative inclination values show true geomagnetic behavior, it would suggest that sediment below 170 mbsf was deposited during the Matuyama Chron; however, this is not consistent with the biostratigraphic data and requires further postcruise analysis.

\section{Physical properties}

Similar to the other sites, the physical properties of the material retrieved at Site U1398 can be correlated to the lithologic variations observed in the recovered material (Figs. F14, F15). Magnetic susceptibility varies between $1000 \times 10^{-5}$ and $2500 \times 10^{-5}$ SI (maximum $=$ $6700 \times 10^{-5} \mathrm{SI}$ ) in the sediment containing considerable amounts of volcanic clasts (mainly andesitic in composition) and is mostly below $700 \times 10^{-5} \mathrm{SI}$ in the hemipelagic sediment. Usually, magnetic susceptibility also decreases with decreasing grain size in normally graded volcaniclastic layers. NGR varies inversely with magnetic susceptibility. It shows count rates as high as $35 \mathrm{cps}$ in the hemipelagic sediment and count rates as low as 8 cps in the volcaniclastic sediment. $P$-wave velocities vary between 1650 and $1850 \mathrm{~m} / \mathrm{s}$ in the volcaniclastic sediment and between 1500 and $1600 \mathrm{~m} / \mathrm{s}$ in the hemipelagic sediment. Bulk density and $P$-wave velocity decrease with grain size in normally graded turbiditic sequences. Shear strength measurements were not performed in the uppermost 40 and 60 mbsf of Holes U1398A and U1398B, respectively, because of the presence of sandy and gravelly sediment. Below these depths, although the shear strength measurements show considerable scatter, a general trend of increasing shear strength is observed. Porosity in the hemipelagic sediment ranges between $60 \%$ and $75 \%$, and, as at the other sites, no trend with depth was observed. Porosity in the volcaniclastic deposits varies between $39 \%$ and $67 \%$; however, calculated porosity values in volcaniclastic sediment may be inaccurate due either to pore water draining or grain reorganization during recovery. Bulk density of the hemipelagic sediment ranges between 1.46 and $1.77 \mathrm{~g} / \mathrm{cm}^{3}$. Volcaniclastic sediment has bulk densities as high as $2.2 \mathrm{~g} / \mathrm{cm}^{3}$. Grain density of the hemipelagic sediment and volcaniclastic sand shows a range between 2.6 and $2.8 \mathrm{~g} / \mathrm{cm}^{3}$. Temperature was measured using the APCT- 3 at 45.6 and 60.4 mbsf in Hole U1398A and 26.5, 58.1, and $73.8 \mathrm{mbsf}$ in Hole U1398B. The temperature gradient is $57.4^{\circ} \pm 5.0^{\circ} \mathrm{C} / \mathrm{km}$. Using the measured thermal conductivity of $1.034 \mathrm{~W} /(\mathrm{m} \cdot \mathrm{K})$, with standard error on the mean of $0.012 \mathrm{~W} /(\mathrm{m} \cdot \mathrm{K})$, the implied conductive heat flow is $59 \pm 5 \mathrm{~mW} / \mathrm{m}^{2}$. No bathymetric correction is needed, and sedimentation may lower the measured near-surface heat flow by as much as $4 \%$ (Manga et al., 2012).

\section{Geochemistry}

Twenty-three headspace samples were analyzed for gas content. Methane concentrations are very low (a few parts per million) in the upper parts of the sediment retrieved from Site U1398 but increase rapidly below 180 mbsf to a maximum value of $4700 \mathrm{ppm}$ at 240 mbsf. Despite these elevated methane levels, concentrations of the higher hydrocarbons remained close to detection limits, with between 0.4 and $1.4 \mathrm{ppm}$ ethane and ethene measured in seven samples. Because of the coarse-grained nature of the sediment, it was not possible to take any pore water samples in the uppermost 60 mbsf at this site. Hence, the uppermost pore water data come from 62.5 mbsf. At this point, pore water alkalinity values are close to $10 \mathrm{mM}$ and remain at this level to $150 \mathrm{mbsf}$. Alkalinity then decreases to $5.9 \mathrm{mM}$ at $254 \mathrm{mbsf}$. Ammonium concentrations increase steadily from $0.8 \mathrm{mM}$ in the shallowest samples to $\sim 1.6 \mathrm{mM}$ in the deepest sample. Calcium concentrations decrease from $4.8 \mathrm{mM}$ at $62.5 \mathrm{mbsf}$ to $3.4 \mathrm{mM}$ at $86 \mathrm{mbsf}$ and then remain relatively constant with an increase to $10.9 \mathrm{mM}$ in the deepest sample (Fig. F15). Magnesium concentrations also gradually decrease from $51 \mathrm{mM}$ in the shallowest sample to $44.4 \mathrm{mM}$ at the base of the hole. Chloride concentrations show a consistent increase from close to the seawater value in the shallowest sample to $674 \mathrm{mM}$ at $254 \mathrm{mbsf}$. Even the shallowest sample has sulfur concentrations that are less than half the seawater level, and then concentrations fall below $10 \mathrm{mM}$ at $65 \mathrm{mbsf}$ and reach our detection limit by $\sim 160$ mbsf. Overall, data are consistent with diagenetic processes controlled by organic carbon oxidation and alteration of volcanic material. The increase in chloride with depth may reflect hydration of clay minerals.

\section{Site U1399}

\section{Background and objectives}

IODP Site U1399 (proposed Site CARI-08B; $14^{\circ} 23.24^{\prime} \mathrm{N}, 61^{\circ} 42.69^{\prime} \mathrm{W} ; 2900 \mathrm{mbsl}$ ) is located west of Martinique (Fig. F11; Table T1). The objective for Site U1399 was to characterize the processes accompanying debris avalanche emplacement and associated erosion. The seismic and bathymetric surveys for Site U1399 revealed that this site is located on one of the main chaotic deposits and that coring at this site could retrieve volcanic and biogenic sediment with intercalated, large, chaotic unit (interpreted as debris avalanche Deposit 1) (Le Friant et al., 2003; Boudon et al., 2007). In detail, we hope to characterize 
and quantify the erosional processes of the upper sedimentary layers deposited in the Grenada Basin associated with such mass transport processes and their subsequent incorporation into the flow. Finally, we will compare the characteristics of the deposits from Dominica and Martinique to constrain possible differences in erosional capability and mobility. Sediment above Deposit 1 will be used to better constrain the age of the mass-wasting event.

\section{Scientific results}

\section{Lithostratigraphy}

Sediment cored at Site U1399 is dominated by a combination of hemipelagic mud with interbedded tephra and volcaniclastic turbidites, as well as various types of deformed sedimentary intervals that occur at different depths (Figs. F16, F17). Eight lithostratigraphic units (Units A-H) were defined based either on characteristic changes throughout the cored material or distinct marker layers. Unit A (0-24 mbsf in Hole U1399A and 0-12 mbsf in Hole U1399B) is mainly composed of hemipelagic mud with abundant interbedded tephra layers. In Hole U1399A, several small turbidites are also interbedded with hemipelagic mud, whereas only one turbidite could be identified in Hole U1399B. Most tephra and turbidite layers contain pumice in variable abundances $(5 \%-$ 65\%). Unit B (24-50.5 mbsf in Hole U1399A and 1229 mbsf in Hole U1399B) is composed of a thick sequence of variably deformed hemipelagic sediment with several areas of inclined and convoluted banding. This unit also contains debris flow deposits (debrites) with a muddy sand matrix. Dispersed lava clasts and deformed tephra layers are often found within the debrites. Unit C (50.5-72 mbsf in Hole U1399A and 29-53 mbsf in Hole U1399B) consists of hemipelagic mud with interbedded tephra layers and thin turbidites $(<1 \mathrm{~m}$ thick). The base of Unit $\mathrm{C}$ is composed of a $1 \mathrm{~m}$ thick interval of hemipelagic mud overlain by a turbidite. This basal turbidite is $8.2 \mathrm{~m}$ thick in Hole U1399A and $2.1 \mathrm{~m}$ thick in Hole U1399B. The upper part of Unit D (72-76 mbsf in Hole U1399A and 53-68.5 mbsf in Hole U1399B) is composed of deformed sediment with inclined contacts between zones of different colored mud, whereas the lower part is composed of weakly deformed hemipelagic mud with inclined green laminae. Unit E (76112 mbsf in Hole U1339A and 68.5-102.7 mbsf in Hole U1339B) consists of a succession of alternating layers of undeformed hemipelagic mud with interbedded tephras and thin turbidites, deformed hemipelagic mud, debrites, and thick turbidites. Unit F (112-142.5 mbsf in Hole U1399A and 102.7129 mbsf in Hole U1399B) is composed of a thick sequence of highly deformed and contorted sediment, including some turbidites and contorted tephra layers.
Unit G (142.5-191.7 mbsf in Hole U1399A and 129182.3 mbsf in Hole U1399B) is mainly composed of thick sequences of pumice-rich turbidites with interbedded hemipelagic mud containing a few tephra layers. The proportion of hemipelagic mud in this unit is low. Unit H (191.7-270 mbsf in Hole U1399A) is mainly composed of hemipelagic mud, with interbedded tephra layers and pumice-rich turbidites. The proportion of hemipelagic mud (70\%) is higher than in preceding units, and tephra layers are frequently observed.

As shown by the carbonate analysis of 33 samples throughout the entire cored interval, calcium carbonate concentrations are highly variable and are lower in intervals with higher proportions of volcanic material and presumably terrestrial clay. The maximum concentration is $\sim 35 \mathrm{wt} \%$, which also partly reflects the absence of significant aragonite preservation.

\section{Paleontology and biostratigraphy}

Core catcher samples taken from Site U1399 contain calcareous nannofossils and planktonic and benthic foraminifers of varying abundances and at varying levels of preservation. Calcareous nannofossil and planktonic foraminiferal datums obtained from the cored material show that the sediments were deposited during the late Pleistocene, indicating an extremely high sedimentation rate for this site. Reworking of much older (early Pleistocene and late Pliocene) material is evident in several samples. Many of the core catcher samples from Site U1399 consist of very coarse grained material containing numerous shallowwater benthic foraminifers and fragments of shell and coral. Well-preserved pteropod and heteropod shells, otoliths, and sponge spicules (Demospongiae) were also found in some of the hemipelagic samples. The nannofossil assemblage was dominated by Gephyrocapsa oceanica, Gephyrocapsa parallela, Helicosphaera hyalina, and Emiliania huxleyi, though several samples contained obviously reworked species (the early Paleocene species, Binatholithus sparsus, for example). The assemblage of observed planktonic foraminifers was diverse but dominated by Globigerinoides ruber (white and pink), Globigerinoides sacculifer, and Neogloboquadrina dutertrei (dextral). Other abundant species include Globorotalia truncatulinoides and Globorotalia tumida. The assemblage does not change significantly throughout the site, and all species present are indicative of warm subtropical waters. Several datum species were found; however, marker species were generally not found in samples with low planktonic foraminifer abundance. Globorotalia flexuosa (0.07-0.40 Ma) and Globigerinella calida (B $0.22 \mathrm{Ma}$ ) were only found in low numbers. The last occurrences of these datum species are not 
clearly defined, and no reliable planktonic foraminiferal datum was found at the base of either hole. Many reworked specimens were found within the samples, from early Pliestocene to possible Miocene. Again, because of the lack of certain obvious species, a paleodepth estimate based on benthic foraminifers is difficult, but based on the presence of Cibicides wuellerstorfi and Pyrgo murrhina, a bathyal paleodepth is interpreted.

\section{Paleomagnetism}

Interpretation of the behavior of the geomagnetic field during the deposition of cored sediment to derive a magnetostratigraphic record is based only on the data from nondeformed intervals. This is roughly $20 \%$ of the paleomagnetic directional data obtained from Site U1399, resulting in a highly discontinuous record. Expected inclination for the site is $\pm 27.2^{\circ}$ assuming a GAD. Between 0 and 207.5 mbsf in Hole U1399A and in all of Hole U1399B, SRM and discrete inclination data show scattered but positive values, clustering around the expected GAD inclination. Declination also shows some scatter, but coupled with the positive inclination data it suggests all sediment was deposited under normal polarity conditions. Interpretation is severely hampered because of the lack of a continuous record, and we cannot unequivocally say that all sediment was deposited within the Brunhes chron; however, this would indicate a late Pleistocene age for the site.

\section{Physical properties}

Unlike previous sites, magnetic susceptibility data obtained from the cored material at Site U1399 show no clear variation with the material recovered (Figs. F16, F17). Only two strong peaks correlating to thick layers of coarse-grained volcaniclastic material were observed in both holes. Bulk density data scatter around an average value of $1.7 \mathrm{~g} / \mathrm{cm}^{3}$ and generally increase with depth. Bulk density obtained from measurements of discrete hemipelagic samples ranges between 1.5 and $1.8 \mathrm{~g} / \mathrm{cm}^{3}$, displaying a weak positive correlation with depth. Sandy samples have bulk densities as high as $2.05 \mathrm{~g} / \mathrm{cm}^{3}$. Grain density varies between 2.65 and $2.8 \mathrm{~g} / \mathrm{cm}^{3}$. Volcanic sand has a similar grain density compared to hemipelagic samples. Porosity obtained from the measurement of discrete hemipelagic samples ranges between 53\% and $73 \%$. Site U1399 shows a weak negative porositydepth correlation from $\sim 70 \%$ at the mudline to $\sim 60 \%$ at 270 mbsf. Porosity in volcanic sand samples ranges between $40 \%$ and $50 \%$. The porosity of the loose sand may be underestimated by as much as $20 \%$ because of draining pore water during coring, splitting, and sampling. On the other hand, reworking of sand during coring and splitting may increase porosity. NGR data distinguish between hemipelagic sediment and volcanic material, with count rates in the hemipelagic material varying between 15 and $50 \mathrm{cps}$ and count rates in the volcanic material are below 15 cps. $P$-wave velocities obtained from hemipelagic sediment shallower than 140 mbsf range from 1500 to $1550 \mathrm{~m} / \mathrm{s}$, whereas the volcaniclastic material shows velocity values between 1650 and $1800 \mathrm{~m} / \mathrm{s}$. The shear strength of the recovered material generally increases downhole in both holes with higher values typically measured with the handheld penetrometer. Downhole formation temperature was measured using the APCT-3 at 24, 34, 43, and 53 mbsf in Hole U1399A and 25, 53, and $81 \mathrm{mbsf}$ in Hole U1399B. The geothermal gradient is $65.4^{\circ} \pm$ $0.9^{\circ} \mathrm{C} / \mathrm{km}$. Using the measured thermal conductivity of $1.045 \mathrm{~W} /(\mathrm{m} \cdot \mathrm{K})$, with uncertainty on the mean of $0.008 \mathrm{~W} /(\mathrm{m} \cdot \mathrm{K})$, the implied conductive heat flow is $68 \pm 1 \mathrm{~mW} / \mathrm{m}^{2}$. Sedimentation lowers the measured near surface heat flow by as much as $4 \%$. Despite a separation of $410 \mathrm{~m}$ between the two holes cored at this site, all temperature measurements lie on a single line. This implies that fluid flow is not disturbing the temperature gradient.

\section{Downhole logging}

In situ measurements of geophysical properties obtained by the downhole logging operations in Hole U1399C are generally of good quality (Fig. F18). Four different logging units were identified based on specific characteristics observed across the physical properties measured, especially gamma ray, resistivity, and magnetic susceptibility. Logging Unit 1 (80$106 \mathrm{mbsf}$ ) is characterized by an overall increase in gamma radiation with depth from $\sim 25$ to $\sim 50$ gAPI. Magnetic susceptibility and electrical resistivity profiles are similar in character with a small net decrease with depth. At $106 \mathrm{mbsf}$, the transition from logging Unit 1 to logging Unit 2 (106-150 mbsf) is marked by a sharp decrease in gamma radiation that coincides with sharp increases in resistivity and magnetic susceptibility. Similar to logging Unit 1, logging Unit 2 shows a net increase in gamma ray with depth. Between 140 and 150 mbsf, gamma ray values are elevated; this increase is reflected in both the total gamma ray and spectral gamma ray measurements. Interestingly, this increase is not shown in the corresponding NGR data from cores recovered in Hole U1399A. Resistivity generally decreases with depth through this logging unit, with localized high-resistivity features. This trend is repeated in the magnetic susceptibility curve. Logging Unit 3 (150-181 mbsf) is characterized by higher amplitude variability in gamma ray, resistivity, and magnetic susceptibility. Similar to the transition between logging Units 1 
and 2, the transition from logging Unit 2 to logging Unit 3 is marked by a stepwise decrease in gamma radiation and increases in resistivity and magnetic susceptibility. Generally, lower values of gamma radiation coincide with higher values of both resistivity and magnetic susceptibility. Logging Unit 4 (181 mbsf to total hole depth) is characterized by more regular gamma ray variations, on the order of $\sim 15$ gAPI, continuing through the uppermost $25 \mathrm{~m}$ of this unit, after which variations decrease in amplitude. In addition, this unit exhibits the most variable magnetic susceptibility profile in Hole U1399C, including some significant peaks, the largest of which ( 205-208 mbsf) corresponds to similarly elevated values of resistivity. Check shot traveltimes obtained by seismic experiments range from a $0.128 \mathrm{~s}$ two-way traveltime at $87.8 \mathrm{mbsf}$ to $0.279 \mathrm{~s}$ at the bottom of the hole (225.7 mbsf).

\section{Geochemistry}

Twenty-eight samples for headspace analyses were taken throughout the hole. Methane concentrations were only a few parts per million in all but the deepest sample (276 mbsf in Hole U1399A), which yielded a methane concentration of $690 \mathrm{ppm}$. This is slightly deeper than the zone of high methane concentrations observed at Site U1398. The major ion pore water profiles are characteristic of a deep-sea diagenetic sequence. Total sulfur concentrations gradually decrease over the same interval over which alkalinity and ammonium steadily increase. Calcium concentrations show a steady decrease with depth, reflecting precipitation of secondary carbonate (Fig. F17). Magnesium concentrations also decrease with depth, most likely caused by the alteration of volcanic material. The slight increase in chloride concentrations also reflects uptake of water into secondary mineral phases at depth. The shapes of the pore water profiles suggest that the main oxidation of organic carbon takes place in the uppermost $60 \mathrm{~m}$ of the sediment column. Generally, organic carbon concentrations decrease with depth but are highly scattered. The uppermost $115 \mathrm{~m}$ of the interval cored contain several samples with organic carbon concentrations close to $1 \mathrm{wt} \%$, whereas the maximum concentration observed in the lower $155 \mathrm{~m}$ is $\sim 0.7 \mathrm{wt} \%$. The change in organic carbon concentrations between the upper $115 \mathrm{~m}$ and the lower $155 \mathrm{~m}$ of the sediment column may reflect a change in the input of organic carbon to the system rather than changes in preservation. There is, however, a strong caveat to this hypothesis, as the percentage of volcanic material can also vary with depth, and this may cause variable dilution of a constant input flux of organic carbon to the sediment.

\section{Site U1400}

\section{Background and objectives}

IODP Site U1400 (proposed Site CARI-07C; $14^{\circ} 32.58^{\prime} \mathrm{N}, 61^{\circ} 27.55^{\prime} \mathrm{W} ; 2745 \mathrm{mbsl}$ ) is located west of Martinique (Fig. F11; Table T1). Site U1400 was dedicated to the study of debris avalanche emplacement and associated erosional processes. The evolution of the active Montagne Pelée Volcano is characterized by three major flank-collapse events ( $\sim 0.1$ m.y., $\sim 25,000$ y, and $\sim 9000$ y ago) that systematically destroyed the western flank of the volcano (Le Friant et al., 2003; Boudon et al., 2005, 2007). The volume of material displaced by these collapses varies from 2 to $25 \mathrm{~km}^{3}$, with the debris avalanches depositing into the Grenada Basin. The Pitons du Carbet Volcano experienced a sector collapse $0.3 \mathrm{~m} . \mathrm{y}$. ago (Boudon et al., 1992, 2007; Samper et al., 2007). As shown by bathymetric and seismic data obtained during several site surveys, drilling to $510 \mathrm{mbsf}$ would penetrate through volcanic and biogenic sediment with intercalated large chaotic units (interpreted as debris avalanche Deposits 1 and 2). Of particular interest are the contacts between the different units, not only to distinguish between the different deposits but also to better understand mass transport dynamics, especially in the basal part of the flow. This study will provide fundamental constraints on friction parameters needed for realistic avalanche propagation models. Sediment above the deposit will be dated using $\delta^{18} \mathrm{O}$ chronostratigraphy to better constrain the age of this event. As shown on the seismic profiles, a thick and well-bedded sedimentary layer $(\sim 70 \mathrm{~m})$ overlies Deposit 2 with an abnormal thickness toward the northeast. We will test the hypothesis that, following a flank collapse, the on-land drainage system is drastically modified, resulting in increased erosion and, therefore, increased sedimentation rates in the Grenada Basin.

\section{Scientific results}

\section{Lithostratigraphy}

Sediment retrieved at Site U1400 is divided into seven lithostratigraphic units (Units A-G) (Figs. F19, F20). Generally, this site is dominated by a combination of hemipelagic mud with interbedded tephra, volcaniclastic turbidites, and deformed sediment. Units A-G consist of varying proportions of these different lithologies. Unit A (0-27 mbsf in Hole U1400A and 0-2.94 mbsf in Hole U1400B mbsf) consists of dark gray massive volcanic sand, followed by hemipelagic mud and alternating layers of hemipelagic mud, tephra, and turbidite layers. Pumice is present in variable amounts (5\% to $>60 \%$ ) throughout the entire unit. Unit B ( 27 to $>51$ mbsf in Hole 
U1400A, 2.94-25.5 mbsf in Hole U1400B, and 1522 mbsf in Hole U1400C) is solely composed of volcaniclastic sand. Pumice and scoria clasts were found throughout the entire unit. Unit C (25.5-35 mbsf in Hole U1400B and 22-24.8 mbsf in Hole U1400C) is dominantly composed of gray-green hemipelagic mud with several tephra and two thin turbidite layers. Pumice is abundant in both the tephra layers and the turbidites, with some of the layers containing as much as $90 \%$ pumice. Unit D (35-58 mbsf in Hole U1400B and 24.8-59 mbsf in Hole U1400C) consists of gray and in some places highly mottled gray-green-brown hemipelagic mud with interbedded tephra layers (and a few turbidites in Hole U1400C). With the exception of the uppermost $3 \mathrm{~m}$ (inclination of layers $=\sim 60^{\circ}-70^{\circ}$ ), most of the sediment is weakly deformed (inclinations at $\sim 20^{\circ}$ ) or contorted. Despite its relatively shallow present-day burial depth, the sediment is occasionally highly indurated. Most of the tephra layers contain pumice in various proportions. Unit E (58-212.5 mbsf in Hole U1400B and 59-190 mbsf in Hole U1400C) is composed of primarily hemipelagic mud with numerous interbedded tephra and turbiditic layers, ranging in thickness from a few tens of centimeters to several meters. Most of the tephra layers, as well as the turbidites, contain a significant amount of pumice (varying between $5 \%$ and $60 \%$ ). Generally, the degree of sediment deformation in this unit is much higher (bedding inclination on average $=40^{\circ}$ but ranging as high as $70^{\circ}$ ) than in other units. Unit F (190390 mbsf in Hole U1400C) is composed of a succession of deformed (bedding and contact inclinations as high as $80^{\circ}$ ) and lithified hemipelagic sediment. The unit locally contains many tephra layers. A few muddy-sand debrite intervals, frequently rich in pumice clasts, are observed at different depths within the unit. Unit G (390 to a total depth of 436 mbsf) consists mainly of hemipelagic mud and partly lithified mudstone lacking any signs of sediment deformation. The top of this unit therefore marks the lower boundary of the deformed sediment.

Seventy-eight samples were taken to determine the mineralogical composition (XRD) and carbonate content of the cored sediment. In general, the mineralogy is very similar to the mineralogy obtained at Sites U1398 and U1399. However, subtle variations in the relative proportions of volcanic minerals are present, with quartz and Fe-Ti oxides being more abundant than those seen in the deeper sites. Clay minerals (typically smectite, kaolinite, and glauconite) were identified in virtually every sample and are present in high abundance in some samples. As is typical for sediment cores taken near volcanic islands, carbonate concentrations are highly variable and are lower in intervals with higher proportions of volcanic material. Maximum carbonate concentrations are $\sim 35 \mathrm{wt} \%$, also reflecting the greater proportion of terrestrial clay minerals and the absence of significant aragonite preservation. An unusual aspect of the organic carbon data is a general increase in concentrations with depth. Concentrations in the upper $250 \mathrm{mbsf}$ are generally low (mostly $<0.5 \mathrm{wt} \%$ ) compared to previous sites, whereas approximately half the samples from this depth contain higher organic carbon concentrations, with some samples reaching $0.8 \mathrm{wt} \%$.

\section{Paleontology and biostratigraphy}

Core catcher samples collected at Site U1400 for shipboard biostratigraphic studies contain calcareous nannofossils and planktonic and benthic foraminifers of varying abundances. Calcareous nannofossil and planktonic foraminiferal datums both resolve late Pleistocene ages for the majority of samples. However, at the base of each hole, species indicative of the Pliocene are present. Reworking is evident throughout the material cored at this site. The calcareous nannofossil species observed within the late Pleistocene material are mainly Emiliania huxleyi, Gephyrocapsa parallela, Gephyrocapsa oceanica, Ceratolithus cristatus, Ceratolithus telesmus, and Ceratolithus simplex. Assemblages observed at the base of the site characteristic for the late Pliocene are Discoaster brouweri, Discoaster surculus, Calcidiscus macintyrei, and Discoaster asymmetricus. These samples are assigned to Subzone CN12d. Globigerinoides ruber (white and pink), Globigerinoides sacculifer, and Neogloboquadrina dutertrei (dextral) dominate the assemblage of the planktonic foraminifers. Other abundant species include Pulleniatina obliquiloculata and Sphaeroidinellopsis dehiscens. In all holes, the population changes toward the base to reflect a likely Pliocene assemblage. This change is most obvious in Hole U1400C: in Sample 340-U1400C-36X-CC, P. obliquiloculata is reduced in number; it is absent in Sample 38X-CC, and Globorotalia miocenica and Globorotalia exilis become more abundant. All of these changes reflect a late Pliocene rather than an early Pleistocene foraminiferal assemblage. All species present are indicative of warm subtropical waters. Several datum species were found in all three holes. The most frequently encountered datum species was Globigerinella calida (B $0.22 \mathrm{Ma}$ ). At the bases of Hole U1400A (Sample 340-U1400A-7H-CC), Hole U1400B (Sample 340-U1400B-28H-CC), and Hole U1400C (Samples 340-U1400C-33X-CC through 49X-CC), Globigerinella miocenica (T $2.39 \mathrm{Ma}$ ) becomes quite abundant and most likely reflects the true age of the sediment. Other late Pliocene markers present include Globigerinoides 
extremus (T 1.99 Ma) and G. exilis (T 2.10 Ma), further corroborating the PL5 zonation. Early Pliocene datum species Globorotalia cibaoensis (T $4.60 \mathrm{Ma}$ ) was also found in low numbers throughout the late Pliocene sediment in Hole U1400C. Benthic foraminifers are not present in enough numbers to provide a reliable paleodepth estimate.

\section{Paleomagnetism}

Interpretation of the behavior of the geomagnetic field during the deposition of the cored sediment to derive a magnetostratigraphy that is solely based on the data is restricted to sediment deeper than $\sim 385$ mbsf because of substantial deformation of sediment in the overlying chaotic unit. Based solely on inclination data and because of XCB recovery and rifling of the declination data, negative inclination values tentatively suggest reversed polarity and ages older than 780 k.y. This calculation agrees with biostratigraphic ages for the site.

\section{Physical properties}

Generally, physical properties data obtained from the cored material show consistent changes depending on the lithology recovered (Figs. F19, F20). Magnetic susceptibility data show high values in volcaniclastic material and relatively low values (mostly $<400 \times$ $10^{-5} \mathrm{SI}$ ) in hemipelagic sediment. $P$-wave velocity increases with depth. Above $80 \mathrm{mbsf}, P$-wave velocities are consistent with expected velocities for hemipelagic sediment undergoing normal compaction. Below $80 \mathrm{mbsf}, P$-wave velocity increases at a lower rate. The highest $P$-wave velocities are measured in the volcaniclastic sediment (typically $\sim 1750 \mathrm{~m} / \mathrm{s}$ ) and the lowest in the hemipelagic sediment. Discrete measurements of $P$-wave velocity also indicate a downhole velocity increase in the hemipelagic mud. Again, the volcaniclastic material shows much higher velocities (1700-1840 m/s) than the hemipelagic mud $(1650-1750 \mathrm{~m} / \mathrm{s})$. Porosity in the hemipelagic samples ranges between $51.5 \%$ and $73 \%$, showing a weak decrease with increasing depth. Porosity in the volcaniclastic sand ranges between $36 \%$ and $51 \%$. Observed bulk density in the hemipelagic sediment ranges between 1.5 and $1.82 \mathrm{~g} / \mathrm{cm}^{3}$, displaying a very weak positive correlation with depth. Sandy samples have bulk densities as high as $2.18 \mathrm{~g} / \mathrm{cm}^{3}$, quite distinct from the density of the hemipelagic samples. Grain density in the hemipelagic sediment varies between 2.53 and $2.77 \mathrm{~g} / \mathrm{cm}^{3}$. Grain density in the volcaniclastic material varies between 2.74 and $2.87 \mathrm{~g} / \mathrm{cm}^{3}$. Shear strength measurements showed a significant variability about a trend of shear stress increasing with depth. Sediment expansion observed during core cutting on the catwalk (Holes U1400B and U1400C) suggests that decompression reduces the undrained shear strength $\left(S_{\mathrm{u}}\right)$ of the sediment substantially after retrieval. Downhole temperature was measured using the APCT-3 at 48, 76, and 103 mbsf in Hole U1400C. The temperature gradient is $52.9^{\circ} \pm 1.6^{\circ} \mathrm{C} / \mathrm{km}$. Using the measured thermal conductivity of $1.050 \mathrm{~W} /(\mathrm{m} \cdot \mathrm{K})$, with standard on the mean of $0.006 \mathrm{~W} /(\mathrm{m} \cdot \mathrm{K})$, the implied conductive heat flow is $56 \pm 4 \mathrm{~mW} / \mathrm{m}^{2}$. Bathymetry at this site decreases the near surface heat flow by $2 \%$, and sedimentation lowers the near surface heat flow by as much as $4 \%$ (Manga et al., 2012). There is no evidence for fluid flow affecting temperature.

\section{Geochemistry}

Samples for headspace analyses were taken from 49 cores throughout all three holes at this site. In contrast to the two previous sites in the basin, not a single sample had a methane concentration $>4.1 \mathrm{ppm}$, and the vast majority had concentrations of $<3 \mathrm{ppm}$. No higher hydrocarbons were detected in any of the samples.

The pore water profiles can be, with the exception of the deepest sample from 427 mbsf, readily interpreted in terms of a classic diagenetic profile driven by the oxidation of organic carbon. Calcium and $\mathrm{Mg}$ are generally close to seawater value with some slight depletions, but $\mathrm{Ca}$ concentrations increase and $\mathrm{Mg}$ concentrations decrease with depth near the bottom of the sampled interval. The $\mathrm{Cl}$ data show a steady increase in concentration from the modern seawater value at the surface $(560 \mathrm{mM})$ to $570 \mathrm{mM}$ at $120 \mathrm{mbsf}$, likely reflecting progressive hydration of volcanic material as it is altered to clay minerals. It is interesting to note that the chemical composition of the deepest sample deviates from this interpretation; in particular, it has a much lower $\Sigma$ S concentration than the rest of the samples. This sample comes from much older sediment ( 2 m.y. old) that appears to be separated from the younger overlying sediment by a hiatus of at least $1 \mathrm{~m} . \mathrm{y}$. The two deepest samples also contain the highest organic carbon concentrations. Thus, the pore water geochemistry of the deepest sample seems to reflect a diagenetic environment distinct from that observed in the overlying sediment. This distinction either reflects changes in environmental conditions at this site over time or transport of the upper sediment to this area from a site of lower organic carbon deposition.

\section{Site U1401}

\section{Background and objectives}

IODP Site U1401 (proposed Site CARI-12A; $14^{\circ} 39.10^{\prime} \mathrm{N}, 61^{\circ} 25.08^{\prime} \mathrm{W} ; 2590 \mathrm{mbsl}$ ) is west of 
Martinique (Fig. F11). Site U1401 was dedicated to the characterization of debris avalanche deposits and study of their emplacement processes. The Montagne Pelée Volcano has experienced at least three major flank-collapse events, which systematically destroyed the western flank of the volcano. Previous studies revealed the presence of a debris avalanche deposit with hummocky morphology associated with the 9000-year-old flank collapse (Le Friant et al., 2003; Boudon et al., 2007). Seismic site survey data indicated that Site U1401 could penetrate volcanic and biogenic sediment with intercalated large chaotic units (interpreted as debris avalanche deposits). We expected to drill through mass-wasting Deposit 3 and mass-wasting Deposit 2 from the Montagne Pelée Volcano with the aim of distinguishing the two deposits and also identifying erosive levels or frictional interactions between them. In addition, we expected to recover sediment from the top of the debris avalanche deposit which would allow better age constraint of the event. The data obtained from the sampled sediment will provide valuable insights into the chronology (one or several pulses), the mobility of debris avalanches, and the processes of possible syntransport flow transformation.

\section{Scientific results}

\section{Lithostratigraphy}

Sediment cored at Site U1401 was divided into three lithostratigraphic units (Units A-C) consisting of a combination of hemipelagic mud with interbedded tephra and/or volcaniclastic turbidites (Fig. F21). Unit A (0-8.4 mbsf in Hole U1401A, 0-7.6 mbsf in Hole U1401B, 0-5.7 mbsf in Hole U1401C, and 03.7 mbsf in Hole U1401D) is composed of a thick ungraded to weakly graded volcanic sand layer locally containing some light-colored lava/pumice granules. This sequence is followed by hemipelagic mud with numerous interbedded, poorly sorted, sometimes laminated volcanic sand layers. Most of these layers can be interpreted as tephra layers. However, the thicker layers show planar lamination and poor sorting, suggesting their emplacement was by density flows rather than fallout. In a few places, the sandy tephra layers are separated by fine brown mud, which is most likely volcanic in origin. Unit B (8.414.4 mbsf in Hole U1401A, 7.6-12.9 mbsf in Hole U1401B, 5.7-10.3 mbsf in Hole U1401C, and 3.7$9.25 \mathrm{mbsf}$ in Hole U1401D) is composed of a series of coarse to very coarse volcaniclastic turbidites. These turbidites are as thick as $2 \mathrm{~m}$ and generally normally graded with a basal part rich in gravels and a top part composed of fine to medium sand. At least three or four distinct turbidites are observed. They contain pumices and scoriae in variable proportions, with vesiculated, massive, and oxidized lavas and crystals. The basal part is rich in granules and clasts of gray to reddish gray dense lavas; some of them reach $7 \mathrm{~cm}$ in size. The clasts comprise mainly two-pyroxene andesites or dacites. Interbedded hemipelagic mud in this unit was only observed in Holes U1401A and U1401D. Unit C (14.4-81.5 mbsf in Hole U1401A) is characterized by abundant mafic, vesicular andesite clasts as long as $7 \mathrm{~cm}$, as well as subsidiary amounts of clasts of two-pyroxene andesite.

\section{Paleontology and biostratigraphy}

Core catcher samples from Site U1401 contain calcareous nannofossils and planktonic and benthic foraminifers in generally low abundance and were often found to be barren. Because of the coarse nature of the material collected, very few core catcher samples were adequate for biostratigraphic analysis. However, nannofossil and planktonic foraminiferal content were sufficient to resolve an age of late Pleistocene for this site. In Hole U1401A, Emiliania huxleyi and Gephyrocapsa sp. were observed, dating the material to younger than $0.08 \mathrm{Ma}$ (Zone CN15, E. huxleyi acme zone). One sample (340-U1401D-1HCC) contained abundant planktonic foraminifers, including Globigerinoides ruber (pink and white) and Globigerinoides sacculifer. One datum species, Globigerinella calida (B $0.22 \mathrm{Ma}$ ) was found in that sample, placing this sediment also within the late Pleistocene. No benthic foraminifers were found at this site.

\section{Paleomagnetism}

Interpretation of the behavior of the geomagnetic field during deposition of the cored sediment to derive a magnetostratigraphy is solely based on the generally discontinuous (restricted to the zone above 10 mbsf in all cores) record of hemipelagic sediment cored at this site. Expected inclination for the site is $\pm 27.6^{\circ}$, assuming a GAD model. Inclination data all show positive values and normal GAD-like inclination. Declination shows some scatter, but coupled with the positive inclination data it suggests all sediment was deposited under normal polarity conditions. Using the GPTS of Cande and Kent (1995), this sediment was deposited in the Brunhes Chron and is younger than $780 \mathrm{ka}$. This agrees with the ages obtained from the biostratigraphic studies.

\section{Physical properties}

Physical properties data obtained from the cored material generally show differences based on the lithology retrieved (Fig. F21). In all three holes, peaks in magnetic susceptibility correspond to volcaniclastic beds $\left(2000 \times 10^{-5}\right.$ to $\left.5000 \times 10^{-5} \mathrm{SI}\right)$, whereas low magnetic susceptibility values $\left(<2000 \times 10^{-5} \mathrm{SI}\right)$ 
correspond to hemipelagic mud. In the uppermost 6 mbsf at Hole U1401A, bulk density progressively increases from 1.4 to $2.0 \mathrm{~g} / \mathrm{cm}^{3}$ with depth despite several mud layers interlaced with volcaniclastic sand at these depths. We do not observe this trend in the other three holes at this site. Similar to the behavior of NGR observed at the other sites, NGR is strongly correlated with the mud content in the beds, with more mud resulting in higher NGR counts. The mud layer at $\sim 10.3$ mbsf in Hole U1401B has the highest value of $21 \mathrm{cps}$. The two major lithologies are also clearly identified in $P$-wave velocity patterns, showing low values in the hemipelagic mud (1500$1650 \mathrm{~m} / \mathrm{s}$ ) and higher values in the volcaniclastic material (1650-1800 m/s; maximum of $1860 \mathrm{~m} / \mathrm{s})$. Measurements of $P$-wave velocity obtained from discrete samples also resemble this pattern; hemipelagic mud has velocities of $1530-1660 \mathrm{~m} / \mathrm{s}$, whereas volcaniclastic sand has velocities of 1720-1920 m/s. Density and porosity values obtained from hemipelagic sediment are typical for shallow, buried marine sediment. Porosities are between 50\% and 60\%, and grain densities are $\sim 2.75 \mathrm{~g} / \mathrm{cm}^{3}$. Although measurements are limited, shear strength generally increases with depth from 3-5 $\mathrm{kPa}$ in the upper few meters to $20 \mathrm{kPa}$ at 15 mbsf.

\section{Preliminary scientific assessment}

Expedition 340 involved drilling in marine sediment and volcaniclastic material at nine sites located off the islands of Montserrat and Martinique. The overarching aim of the expedition was to reach a better understanding of the constructive and destructive processes occurring along the Lesser Antilles volcanic arc. Two holes were planned for each of the nine sites, and logging was planned for eight sites. The primary objectives of this expedition were

- To drill through the chaotic units (as identified in the seismic data) interpreted as mass-wasting deposits and to better understand their composition, origin, and relationship to on-land volcanic flank-collapse events;

- To core as many tephra layers as possible for tephrochronology studies designed to reconstruct the history of the volcanoes of both Montserrat and Martinique and the long-term magmatic evolution of the arc; and

- To retrieve a complete sediment record from each of the sites to study the sedimentation processes occurring along the entire volcanic arc.

Sites U1393-U1396 are located in the northern part of the arc, around Montserrat. Sites U1397-U1401 are located in the southern part of the arc close to Martinique.

Sites U1396 and U1397 were chosen to study the magmatic evolution and eruptive history based on the tephrochronology of Montserrat and Martinique, respectively. We achieved our depth and coring objectives completely at Site U1396 (total depth of $139 \mathrm{mbsf}, 296 \mathrm{~m}$ of material, and 104\% recovery) and partly at Site U1397 (total depth of 260 mbsf, $276 \mathrm{~m}$ of material, and 54\% recovery). Sites U1393, U1394, and U1399-U1401 were dedicated to the study of mass-wasting deposits and associated erosional processes. Drilling proved to be extremely difficult in these chaotic, heterogenous formations. However, although core recovery was highly variable, ranging from $11 \%$ to $98 \%$ (Table T1), we were able to recover enough material to study the processes occurring during the emplacement of such deposits. Sites U1395 and U1398 were dedicated to the study of the distal sedimentation processes associated with the deposition of mass-wasting deposits. In total we cored $284 \mathrm{~m}$ (65\% recovery) of material at Site U1395 and 302 m (57\% recovery) at Site U1398. Despite reaching our depth objectives in at least one of the holes at both sites, we did not meet our coring objectives below $\sim 120$ mbsf because of the poor recovery associated with the XCB. Nonetheless, the cored material should be sufficient to conduct the intended scientific studies. Logging was planned for the Hole B at each site, except for Site U1396, which, at $135 \mathrm{mbsf}$, was too shallow for downhole logging. Logging was successfully conducted at Sites U1394, U1395, U1397, and U1399. Because of unfavorable hole conditions, logging was not possible at Sites U1398 and U1400.

Despite the significant difficulties in drilling through the highly heterogeneous sediment, the expedition can be considered a success and the initial objectives were achieved. A total of $2384 \mathrm{~m}$ of core was recovered. We thank the drillers for their unrelenting efforts to drill through such difficult volcaniclastic material and all R/V JOIDES Resolution staff for their collaboration and efficient work on board.

The cores recovered during Expedition 340 are very promising. Postcruise research will provide crucial information to better constrain the evolution of the Lesser Antilles volcanoes. Correlation of the chaotic deposits identified on seismic reflection profiles with sequences of turbidites or deformed marine sediment will lead to a better understanding of processes related to the instabilities of the Lesser Antilles volcanoes, as well as provide new perspectives for studies of similar volcanic settings. 


\section{Mass transport deposits: identify the mechanisms controlling processes and timing of potentially tsunamigenic large mass transport deposit emplacement.}

Sites U1393 and U1394 were dedicated to the study of mass-wasting deposits offshore Montserrat. These landslides included the blocky Deposit 1 and the larger Deposit 2 that contained fewer blocks (Le Friant et al., 2004; Lebas et al., 2011; Watt et al., 2012). Coring conditions for Deposit 1 at Site U1393 were very difficult, with poor recovery caused by the unconsolidated nature of the material being cored. Deposit 2 was successfully cored at Site U1394 with some unexpected results. Based on seismic reflection profiles and previously published criteria (Moore et al., 1989; Urgeles et al., 1997; Deplus et al., 2001; Le Friant et al., 2004; Lebas et al., 2011; Watt et al., 2012), the chaotic unit has been interpreted as masswasting deposits. Watt et al. (2012) inferred that it was a landslide deposit with a significant component of seafloor sediment, based on its smooth top and the local presence of bedded reflectors within the unit on 2-D seismic lines. However, the seismically chaotic unit is dominated by a stacked sequence of predominantly thick, massive, relatively coarsegrained turbidites that range in composition from bioclastic to volcaniclastic. The absence of planar or ripple cross-laminations in the upper part of the deposit suggests rapid deposition. Randomly distributed clasts in the lower part of the chaotic unit may suggest rapid emplacement by a debris flow. Overlying the chaotic unit are hemipelagic sediment and a series of basaltic tephra layers associated with the South Soufrière Hills Volcano (Harford et al., 2002). This gives a minimum age for the unit of $\sim 138 \mathrm{ka}$. However, to fully understand the emplacement processes of the turbidites and their association with the hummocky debris avalanche deposits observed on the upper submarine slope further investigations are required. Among these is the need for correlation between existing seismic data and the cored material. The physical properties data obtained correlate well with the different lithologies recovered. These measurements show that the hemipelagic mud is generally characterized by low values of magnetic susceptibility and $P$-wave velocity but relatively high values of NGR, with a generally low degree of variability of those properties. In contrast, the physical properties of the turbidites are relatively heterogeneous, with overall high values of magnetic susceptibility and $P$-wave velocity but low values of NGR and bulk density.

Three sites (U1399, U1400, and U1401) were dedicated to investigating the chaotic deposits offshore Martinique. Coring conditions at Site U1399 were very good. The first hole was terminated at a total depth of $275 \mathrm{mbsf}$, but the second hole had to be abandoned at 183 mbsf because of unstable hole conditions. At Site U1400 we cored three holes (U1400A, U1400B, and U1400C). Holes U1400A and U1400B were terminated at 51 and 213 mbsf, respectively, because of technical problems, whereas U1400C was terminated at 436 mbsf, reaching the depth objective for this site. Coring conditions at Site U1401 also proved to be difficult. Consequently, a series of short holes were cored instead of one longer hole. The objective at this site was to trace the evolution of the upper $15 \mathrm{~m}$ of material covering the chaotic unit along a $\sim 1 \mathrm{~km}$ transect. Sediment cored at all three sites is dominated by hemipelagic mud with interbedded tephra and volcaniclastic turbidite layers of variable thickness. The sediment recovered at Sites U1399 and U1400 shows signs of severe deformation. Inclined and convoluted banding of hemipelagic sediment combined with deformed tephra or turbiditic layers were observed throughout almost the entire cored interval. Identifying the origin of these deformed units and their relationship with aerial flank-collapse events observed on land (retrogressive sediment failures, submarine slides, etc.) forms a major part of planned postcruise research. Timing of the event that deformed the sediment will be elucidated by $\delta^{18} \mathrm{O}$ dating of the undisturbed sedimentary sequences above and below the chaotic deposit. The study of the processes resulting in the observed fundamental differences between the chaotic deposits sampled offshore Montserrat and offshore Martinique (broadly turbidites versus deformed sediment that has thinner beds and more hemipelagic mud) will also be part of postcruise research. Most likely these differences are related to the emplacement mechanism and the size of the different debris avalanche events, as well as the structure of the sedimentary basin surrounding the islands.

One of the main objectives of this expedition was to better characterize the seismic velocities of the different materials deposited around the Lesser Antilles (e.g., marine sediment versus volcaniclastic material). $P$-wave measurements from both whole-round sections and half sections show velocities ranging from 1500 to $1900 \mathrm{~m} / \mathrm{s}$. Generally, higher velocities (1650 to $>1800 \mathrm{~m} / \mathrm{s}$ ) are obtained from the volcanic layers, whereas lower velocities are obtained from the hemipelagic background sediment (1550 to $1650 \mathrm{~m} / \mathrm{s}$ ). Velocities obtained during the VSP experiment conducted in Hole U1399C are generally higher, ranging from 1997 to $2072 \mathrm{~m} / \mathrm{s}$. These results will help improve estimates of the thickness of the chaotic units, which had previously been made using velocities between 1800 and $2200 \mathrm{~m} / \mathrm{s}$. Data will be processed on shore and will help provide constraints on the seismic 
stratigraphy of the area. Values could also be applied to seismic profiles obtained at other volcanic areas where similar chaotic deposits have been observed.

\section{Tephrochronology studies: characterize the eruptive history, magmatic cycles, and long-term evolution of the arc.}

Site U1396 was dedicated to the tephrochronology study of Montserrat and was successfully cored to 135 mbsf (Hole U1396A) and 139 mbsf (Hole U1396C). Material cored at this site is dominated by hemipelagic sediment with interbedded tephra layers and volcaniclastic sands. More than 180 visible tephra layers were identified, ranging from $<1$ to $>10 \mathrm{~cm}$ in thickness. However, there may be many more crypto-tephra layers embedded within the hemipelagic mud. The magnetostratigraphic record obtained from the cored material is in excellent accordance with biostratigraphic observations. According to the magnetostratigraphy, the basal age of Hole U1396C (139 mbsf) is $4.62 \mathrm{Ma}$; biostratigraphy places the basal age at $>4.48 \mathrm{Ma}$. The highest $\mathrm{CaCO}_{3}$ concentration observed in hemipelagic sediment is $72 \%$, with most samples being much lower than this, indicating that a considerable amount of volcanic material is dispersed throughout the cores, despite the fact that it is not necessarily visible to the naked eye. High recovery and good correlation between both holes mean that this site represents one of the most important stratigraphic records recovered on this expedition. The work planned for the material recovered at this site includes petrological, geochemical, magnetostratigraphic, and biostratigraphic studies to characterize the entire eruptive history of Montserrat. In addition, tephra layers obtained from Site U1395 will be correlated, by geochemical fingerprinting, with tephra layers from Site U1396.

Site U1397 was dedicated to the tephrochronology study of the volcanoes of Martinique and Dominica. Although both holes were drilled $>250$ mbsf, a continuous stratigraphic record was recovered for only the uppermost $120 \mathrm{~m}$. The cored material consisted of combinations of hemipelagic mud, volcaniclastic or mixed (volcaniclastic-bioclastic) turbidites, and abundant tephra layers. At least 200 tephra layers (coming mainly from the Montagne Pelée Volcano) were recorded in the uppermost $28 \mathrm{~m}$ at this site. The turbidites contain variable amounts of fresh pumice in a crystal-rich matrix containing very low proportions of both carbonate material and lava clasts. Below 167 mbsf a larger block composed of andesitic lava containing large phenocrysts of amphibole and quartz was recovered. This lava originates from the Pitons du Carbet Volcano on Martinique and has been dated on-land at $\sim 330-350 \mathrm{ka}$. This age provides a maximum age for the base of the site. This corresponds well with biostratigraphic datums that assign the base of this site to $\sim 400 \mathrm{ka}$ or younger. Numerous tephra layers were also recognized at Sites U1398, U1399, U1400 (especially in the upper part), and U1401, representing material from the more recent history of the volcano. Postcruise research will include a full petrological, geochemical, and granulometric characterization of all identified tephra layers as well as an interhole correlation, based on geochemistry, of the tephra layers. In a final step, these tephra layers will be traced back to possible eruptions recorded on land both in Martinique and Dominica. With the cored material we should be able to reconstruct the entire history of the Montagne Pelée Volcano, which will be important to assess major volcanic hazards as well as volcano evolution.

Volcanoes from the northern and southern parts of the arc have marked differences in chemical composition. Postcruise analyses of the tephra and volcaniclastic turbidites obtained from the north to the south part of the arc will shed light on the evolution of the Lesser Antilles arc.

\section{Sedimentation processes: characterize sedimentation processes along the deep backarc Grenada Basin.}

Three sites were dedicated to studying basin sedimentation processes: Sites U1395 and U1396 in the Bouillante-Montserrat half Graben between Montserrat and Guadeloupe and Site U1398 in the backarc Grenada Basin. Cores recovered at Site U1395 consisted of hemipelagic mud with intercalated turbiditic sand and tephra. The majority of turbidites probably come from Montserrat. However, in the lower part ( $90-100 \mathrm{mbsf})$, interbedded in the background sediment, are numerous layers of sand-sized volcanic material consisting of lava fragments, scoria, plagioclase, pyroxene, and, rarely, amphibole. This composition is characteristic for tephra deposits originating from volcanoes in the central part of Guadeloupe. The magnetostratigraphy indicates a polarity change indicative of the end of the Jaramillo Chron (0.99 Ma) around 90 mbsf in both Hole U1395A and Hole U1395B. This polarity change suggests sedimentation rates of $9 \mathrm{~cm} / \mathrm{k}$.y. above $90 \mathrm{mbsf}$ and the ability to study a continuous record of sedimentation over 1 m.y. The sedimentation record for Site U1396 reaches as far back as $\sim 4.62 \mathrm{Ma}$, as indicated by the magnetostratigraphic study and in agreement with the biostratigraphic studies done at this site. Using the GPTS of Cande and Kent (1995), nine periods of normal polarity and nine periods of reversed polarity could be identified for this site. The earliest polarity 
reversal we see is the beginning of Chron C3n.1n $(4.29 \mathrm{Ma})$ at $129.4 \mathrm{mbsf}$ in Hole U1396A, giving this hole a basal age of 4.29-4.48 Ma. The longer Hole U1396C record contains the end of Chron C3n.2n $(4.48 \mathrm{Ma})$, giving this hole a basal age of 4.48 $4.62 \mathrm{Ma}$. Average sedimentation rate for this site is $3.1 \mathrm{~cm} / \mathrm{k} . \mathrm{y}$. However, sedimentation rates vary over the observed depth interval cored at this site. Pliocene sedimentation rates are on the order of $4 \mathrm{~cm} / \mathrm{k} . \mathrm{y}$., whereas Pleistocene rates are $1.7 \mathrm{~cm} / \mathrm{k} . \mathrm{y}$. and rates from the base of the core to the beginning of the Gauss Chron (3.58 Ma) are $5.3 \mathrm{~cm} / \mathrm{k} . \mathrm{y}$.

Site U1398 is located in the backarc Grenada Basin. The upper part of the site is dominated by volcaniclastic turbidites, whereas the lower portions are composed of various combinations of hemipelagic sediment with intercalated volcaniclastic turbidites and tephra. Abundant pumice clasts are common throughout the upper parts. XRD data obtained from discrete samples throughout the cores show that quartz and plagioclase dominate the volcanic material, whereas the marine sediment is dominated by calcite and lesser amounts of aragonite. Postcruise research will help to distinguish deposits from Dominica and Martinique by comparison with on-land products and geochemical fingerprinting. Based on detailed biostratigraphic studies, the cored material could be assigned to the late Pleistocene, indicating extremely high sedimentation rates in comparison with Site U1395. However, reworking of much older material is evident in several studied samples.

With the long-reaching sediment record obtained at these sites we will be able to conduct the desired research. Postcruise studies aim at comparing the sedimentation processes in the north and the south parts of the arc, correlating turbidites with volcanic activities (composition, petrology, geochemistry, and granulometry), refining the magnetostratigraphicbased chronology, and undertaking a complete provenance analysis of the hemipelagic sediment recovered.

\section{References}

Annen, C., Blundy, J.D., and Sparks, R.S.J., 2006. The genesis of intermediate and silicic magmas in deep crustal hot zones. J. Petrol., 47(3):505-539. doi:10.1093/petrology/egi084

Annen, C., Pichavant, M., Bachmann, O., and Burgisser, A., 2008. Conditions for the growth of a long-lived shallow crustal magma chamber below Mount Pelee Volcano (Martinique, Lesser Antilles arc). J. Geophys. Res., [Solid Earth], 113(B7):B07209. doi:10.1029/2007JB005049

Boudon, G., Le Friant, A., Komorowski, J.-C., Deplus, C., and Semet, M.P., 2007. Volcano flank instability in the Lesser Antilles arc: diversity of scale, processes, and temporal recurrence. J. Geophys. Res., [Solid Earth], 112(B8):B08205. doi:10.1029/2006JB004674

Boudon, G., Le Friant, A., Villemant, B., and Viodé, J.-P., 2005. Martinique. In Lindsay, J.M., Robertson, R.E.A., Shepherd, J.B., and Ali, S. (Eds.), Volcanic Hazard Atlas of the Lesser Antilles: Trinidad and Tobago, West Indies (Seismic Research Unit, Univ. West Indies), 65-102.

Boudon, G., Paterne, M., Erlund, E., Duchoiselle, L., and Villemant, B., 2004. A review of the recent volcanic activity of Montagne Pelée (Martinique): correlation between on land and marine tephrochonologic data [IAVCEI 2004 General Assembly, Pucón, Chile, 14-19 November 2004].

Boudon, G., Paterne, M., Machault, J., Villemant, B., Komorowski, J.-C., and Le Friant, A., 2008. Volcanic activity in the Lesser Antilles arc: correlation between on-land and marine tephrochronologic data [IAVCEI 2008 General Assembly, Reykjavík, Iceland, 17-22 August 2008].

Boudon, G., Semet, M.P., and Vincent, P.M., 1992. Major flank collapse at Pitons du Carbet Volcano, Martinique: one of the largest similar structures in the Lesser Antilles arc. Proc. Int. Geol. Congr., 29th, 505. (Abstract)

Boudon, G., Villemant, B., Le Friant, A., Paterne, N., and Cortijo, E., submitted. Role of large flank collapse events on magma exsolution of volcanoes: insights from the Lesser Antilles arc. J. Volcanol. Geotherm. Res.

Bouysse, P., and Guennoc, P., 1983. Donnees sur la structure de l'arc insulaire des Petites Antilles, entre Ste-Lucie et Anguilla. Mar. Geol., 53(1-2):131-166. doi:10.1016/ 0025-3227(83)90038-5

Bouysse, P., Westercamp, D., and Andreieff, P., 1990. The Lesser Antilles island arc. In Moore, J.C., Mascle, A., et al., Proc. ODP, Sci. Results, 110: College Station, TX (Ocean Drilling Program), 29-44. doi:10.2973/ odp.proc.sr.110.166.1990

Briden, J.C., Rex, D.C., Faller, A.M., and Tomblin, J.F., 1979. K-Ar geochronology and palaeomagnetism of volcanic rocks in the Lesser Antilles island arc. Philos. Trans. R. Soc., A, 291(1383):485-528. http:// www.jstor.org/stable/75166

Cande, S.C., and Kent, D.V., 1995. Revised calibration of the geomagnetic polarity timescale for the Late Cretaceous and Cenozoic. J. Geophys. Res., [Solid Earth], 100(B4):6093-6095. doi:10.1029/94JB03098

Carey, S.N., and Sigurdsson, H., 1982. Influence of particle aggregation on deposition of distal tephra from the May 18, 1980, eruption of Mount St. Helens Volcano. J. Geophys. Res., [Solid Earth], 87(B8):7061-7072. doi:10.1029/ JB087iB08p07061

Cassidy, M., Trofimovs, J., Watt, S.F.L., Palmer, M.R., Taylor, R.N., Gernon, T.M., Talling, P.J., and Le Friant, A., in press. Multi-stage collapse events in the South Soufrière Hills, Montserrat, as recorded in marine sediment cores. In Wadge, G., Robertson, R., and Voight, B. (Eds.), The Eruption of Soufriere Hills Volcano, Montserrat, from 2000 to 2010. Mem.-Geol. Soc. London.

Clavero, J., Sparks, R., Huppert, H., and Dade, W., 2002. Geological constraints on the emplacement mechanism 
of the Parinacota debris avalanche, northern Chile. Bull. Volcanol., 64(1):40-54. doi:10.1007/s00445-001-0183-0

Deplus, C., Le Friant, A., Boudon, G., Komorowski, J.-C., Sparks, S., and Harford, C., 2002. Numerous debris avalanche deposits off the southern part of Montserrat revealed by recent oceanographic cruises [Montagne Pelée 1902-2002: Explosive Volcanism in Zones of Subduction, St. Pierre, Martinique Island, 12-16 May 2002].

Deplus, C., Le Friant, A., Boudon, G., Komorowski J.-C., Villemant, B., Harford, C., Ségoufin, J., and Cheminée, J.-L., 2001. Submarine evidence for large-scale debris avalanches in the Lesser Antilles arc. Earth Planet. Sci. Lett., 192(2):145-157. doi:10.1016/S0012821X(01)00444-7

Duchoiselle, L., 2003. Téphrochronologie des produits émis au cours de l'activité récente de la Montagne Pelée, Martinique [DEA de Géophysique Interne]. Institut de Physique du Globe de Paris (IPGP), Univ. Paris VII.

Feuillet, N., Manighetti, I., Tapponnier, P., and Jacques, E., 2002. Arc parallel extension and localization of volcanic complexes in Guadeloupe, Lesser Antilles. J. Geophys. Res., [Solid Earth], 107(B12):2331-2359. doi:10.1029/ 2001JB000308

Garcia, M.O., 1993. Pliocene-Pleistocene volcanic sands from Site 842: products of giant landslides. In Wilkens, R.H., Firth, J., Bender, J., et al., Proc. ODP, Sci. Results, 136: College Station, TX (Ocean Drilling Program), 5363. doi:10.2973/odp.proc.sr.136.204.1993

Garcia, M.O., and Hull, D.M., 1994. Turbidites from giant Hawaiian landslides; results from Ocean Drilling Program Site 842. Geology, 22(2):159-162. doi:10.1130/ 0091-7613(1994)022<0159:TFGHLR>2.3.CO;2

Garcia, M.O., Sherman, S.B., Moore, G.F., Goll, R., PopovaGoll, I., Natland, J.H., and Acton, G., 2006. Frequent landslides from Koolau Volcano: results from ODP Hole 1223A. J. Volcanol. Geotherm. Res., 151(1-3):251-268. doi:10.1016/j.jvolgeores.2005.07.035

Gardner, J.V., Nelson, C.S., and Baker, P.A., 1986. Distribution and character of pale green laminae in sediment from Lord Howe Rise: a probable late Neogene and Quaternary tephrostratigraphic record. In Kennett, J.P., von der Borch, C.C., et al., Init. Repts. DSDP, 90: Washington, DC (U.S. Govt. Printing Office), 1145-1159. doi:10.2973/dsdp.proc.90.125.1986

Gee, M.J.R., Masson, D.G., Watts, A.B., and Allen, P.A., 1999. The Saharan debris flow: an insight into the mechanics of long runout submarine debris flows. Sedimentology, 46(2):317-335. doi:10.1046/j.13653091.1999.00215.x

Gérard, M., and Person, A., 1994. Low hydrothermal impact in volcaniclastic sediments of the north Aoba Basin: Sites 832 and 833. In Greene, H.G., Collot, J.-Y., Stokking, L.B., et al., Proc. ODP, Sci. Results, 134: College Station, TX (Ocean Drilling Program), 131-176. doi:10.2973/odp.proc.sr.134.038.1994

Germa, A., Quidelleur, X., Lahitte, P., Labanieh, S., and Chauvel, C., 2011. The K-Ar Cassignol-Gillot technique applied to western Martinique lavas: a record of Lesser Antilles arc activity from 2 Ma to Mount Pelée volca- nism. Quat. Geochronol., 6(3-4):341-355. doi:10.1016/ j.quageo.2011.02.001

Glicken, H., 1991. Sedimentary architecture of large volcanic-debris avalanches. In Fisher, R.V., and Smith, G.A. (Eds.), Sedimentation in Volcanic Settings. Spec. Publ._SEPM (Soc. Sediment. Geol.), 45:99-106. doi:10.2110/pec.91.45.0099

Glicken, H., 1996. Rockslide-debris avalanche of May 18, 1980, Mount St. Helens Volcano, Washington. Open-File Rep.-U. S. Geol. Surv., 96-677. http://vulcan.wr.usgs.gov/Projects/Glicken/OFR96-677.pdf

Goldstrand, P.M., 1998. Provenance and sedimentologic variations of turbidite and slump deposits at Sites 955 and 956. In Weaver, P.P.E., Schmincke, H.-U., Firth, J.V., and Duffield, W. (Eds.), Proc. ODP, Sci. Results, 157: College Station, TX (Ocean Drilling Program), 343-360. doi:10.2973/odp.proc.sr.157.122.1998

Harford, C.L., Pringle, M.S., Sparks, R.S.J., and Young, S.R., 2002. The volcanic evolution of Montserrat using ${ }^{40} \mathrm{Ar} /$ ${ }^{39} \mathrm{Ar}$ geochronology. Mem.-Geol. Soc. London, 21:93113. doi:10.1144/GSL.MEM.2002.021.01.05

Hart, K., Carey, S., Sigurdsson, H., Sparks, R.S.J., and Robertson, R.E.A, 2004. Discharge of pyroclastic flows into the sea during the 1996-1998 eruptions of the Soufrière Hills Volcano, Montserrat. Bull. Volcanol., 66(7):599614. doi:10.1007/s00445-004-0342-1

Herd, R.A., Edmonds, M., and Bass, V.A., 2005. Catastrophic lava dome failure at Soufrière Hills Volcano, Montserrat, 12-13 July 2003. J. Volcanol. Geotherm. Res., 148(34):234-252. doi:10.1016/j.jvolgeores.2005.05.003

Holcomb, R.T., and Searle, R.C., 1991. Large landslides from oceanic volcanoes. Mar. Geotechnol., 10(1-2):1932. doi:10.1080/10641199109379880

Hunt, J.E., Wynn, R.B., Masson, D.G., Talling, P.J., and Teagle., D.A.H., 2011. Sedimentological and geochemical evidence for multistage failure of volcanic island landslides: a case study from Icod landslide on north Tenerife, Canary Islands. Geochem., Geophys., Geosyst., 12:Q12007. doi:10.1029/2011GC003740

Ida, Y., and Voight, B. (Eds.), 1995. Models of Magmatic Processes and Volcanic Eruptions. J. Volcanol. Geotherm. Res., 66(1-4).

Komorowski, J.-C., Boudon, G., Semet, M., Beauducel, F., Anténor-Habazac, C., Bazin, S., and Hammouya, G., 2005. Guadeloupe. In Lindsay, J.M., Robertson, R.E.A., Shepherd, J.B., and Ali, S. (Eds.), Volcanic Hazard Atlas of the Lesser Antilles: Trinidad and Tobago, West Indies (Seismic Research Unit, Univ. West Indies), 68-105.

Komorowski, J.-C., Glicken, H.X., and Sheridan, M.F., 1991. Secondary electron imagery of microcracks and hackly fracture surfaces in sand-size clasts from the 1980 Mount St. Helens debris-avalanche deposit: implications for particle-particle interactions. Geology, 19(3):261-264. doi:10.1130/00917613(1991)019<0261:SEIOMA >2.3.CO;2

Krastel, S., Schmincke, H.-U., Jacobs, G.L., Rihm, R., Le Bas, T.P., and Alibés, B., 2001. Submarine landslides around the Canary Islands. J. Geophys. Res., [Solid Earth], 106(B3):3977-3997. doi:10.1029/2000JB900413 
Labazuy, P., 1996. Recurrent landslides events on the submarine flank of Piton de la Fournaise Volcano (Reunion Island). Geol. Soc. Spec. Publ., 110(1):295-306.

doi:10.1144/GSL.SP.1996.110.01.23

Lebas, E., Le Friant, A., Boudon, G., Watt, S.F.L., Talling, P.J., Feuillet, N., Deplus, C., Berndt, C., and Vardy, M.E., 2011. Multiple widespread landslides during the longterm evolution of a volcanic island: insights from highresolution seismic data, Montserrat, Lesser Antilles. Geochem., Geophys., Geosyst., 12(5):Q05006. doi:10.1029/ 2010GC003451

Le Friant, A., 2001. Les déstabilisations de flanc des volcans actifs de l'arc des Petites Antilles: origines et conséquences [Thèse doctorat]. Univ. Paris.

Le Friant, A., Boudon, G., Deplus, C., and Villemant, B., 2003a. Large-scale flank collapse events during the activity of Montagne Pelée, Martinique, Lesser Antilles. J. Geophys. Res., [Solid Earth], 108(B1):2055. doi:10.1029/2001JB001624

Le Friant, A., Boudon, G., Komorowski, J.-C., and Deplus, C., 2002. L'île de la Dominique, à l'origine des avalanches de débris les plus volumineuses de l'arc des Petites Antilles. C. R. Geosci., 334(4):235-243. doi:10.1016/S1631-0713(02)01742-X

Le Friant, A., Deplus, C., Boudon, G., Feuillet, N., Trofimovs, J., Komorowski, J.-C., Sparks, R.S.J., Talling, P., Loughlin, S., Palmer, M., and Ryan, G., 2010. Eruption of Soufrière Hills (1995-2009) from an offshore perspective: insights from repeated swath bathymetry surveys. Geophys. Res. Lett., 37(11):L11307. doi:10.1029/ 2010GL043580

Le Friant, A., Deplus, C., Boudon, G., Sparks, R.S.J., Trofimovs, J., and Talling, P., 2009. Submarine deposition of volcaniclastic material from the 1995-2005 eruptions of Soufrière Hills Volcano, Montserrat. J. Geol. Soc. (London, U. K.), 166(4):171-182. doi:10.1144/0016-76492008047

Le Friant, A., Harford, C.L., Deplus, C., Boudon, G., Sparks, R.S.J., Herd, R.A., and Komorowski, J.C., 2004. Geomorphological evolution of Montserrat (West Indies): importance of flank collapse and erosional processes. $J$. Geol. Soc. (London, U. K.), 161(1):147-160. doi:10.1144/ 0016-764903-017

Le Friant, A., Heinrich, P., Deplus, C., and Boudon, G., 2003b. Numerical simulation of the last flank-collapse event of Montagne Pelée, Martinique, Lesser Antilles. Geophys. Res. Lett., 30(2):1034. doi:10.1029/ 2002GL015903

Le Friant, A., Ishizuka, O., and Stroncik, N., 2011. Lesser Antilles volcanism and landslides: drilling volcanic landslides deposits and volcanoclastic sediments in the Lesser Antilles arc: implications for hazard assessment and long-term magmatic evolution of the arc. IODP Sci. Prosp., 340. doi:10.2204/iodp.sp.340.2011

Le Friant, A., Lock, E.J., Hart, M.B., Boudon, G., Sparks, R.S.J., Leng, M.J., Smart, C.W., Komorowski, J.C., Deplus, C., and Fisher, J.K., 2008. Late Pleistocene tephrochronology of marine sediments adjacent to Montserrat, Lesser Antilles volcanic arc. J. Geol. Soc.
(London, U. K.), 165(1):279-289. doi:10.1144/001676492007-019

Lindsay, J.M., Robertson, R.E.A., Shepherd, J.B., and Ali, S. (Eds.), 2005a. Volcanic Hazard Atlas of the Lesser Antilles: Trinidad and Tobago, West Indies (Seismic Research Unit, Univ. West Indies).

Lindsay, J.M., Smith, A.L., Roobol, M.J., and Stasiuk, M.V., 2005b. Dominica. In Lindsay, J.M., Robertson, R.E.A., Shepherd, J.B., and Ali, S. (Eds.), Volcanic Hazard Atlas of the Lesser Antilles: Trinidad and Tobago, West Indies (Seismic Research Unit, Univ. West Indies), 2-46.

Lindsay, J.M., Trumbull, R.B., and Siebel, W., 2005c. Geochemistry and petrogenesis of late Pleistocene to recent volcanism in southern Dominica, Lesser Antilles. J. Volcanol. Geotherm. Res., 148(3-4):253-294. doi:10.1016/ j.jvolgeores.2005.04.018

Lipman, P.W., Normark, W.R., Moore, J.G., Wilson, J.B., and Gutmacher, C.E., 1988. The giant submarine Alika debris slide, Mauna Loa, Hawaii. J. Geophys. Res., [Solid Earth], 93(B5):4279-4299. doi:10.1029/ JB093iB05p04279

Macdonald, R., Hawkesworth, C.J., and Heath, E., 2000. The Lesser Antilles volcanic chain: a study in arc magmatism. Earth-Sci. Rev., 49(1-4):1-76. doi:10.1016/ S0012-8252(99)00069-0

Machault, J., 2008. Les éruptions ponceuses des volcans actifs de la Guadeloupe et de la Dominique (arc des Petites Antilles). Corrélation entre dépôts à terre et en mer [M.S. thesis]. Univ. d'Orsay, France.

Manga, M., Hornbach, M.J., Le Friant, A., Ishizuka, O., Stroncik, N., Adachi, T., Aljahdali, M., Boudon, G., Breitkreuz, C., Fraass, A., Fujinawa, A., Hatfield, R., Jutzeler, M., Kataoka, K., Lafuerza, S., Maeno, F., Martinez-Colon, M., McCanta, M., Morgan, S., Palmer, M.R., Saito, T., Slagle, A., Stinton, A.J., Subramanyam, K.S.V., Tamura, Y., Talling, P.J., Villemant, B., Wall-Palmer, D., and Wang, F., 2012. Heat flow in the Lesser Antilles island arc and adjacent backarc Grenada Basin. Geochem., Geophys., Geosyst., 13:Q08007. doi:10.1029/2012GC004260

Martin, J.B., 1994. Diagenesis and hydrology at the New Hebrides forearc and intra-arc Aoba Basin. In Greene, H.G., Collot, J.-Y., Stokking, L.B., et al., Proc. ODP, Sci. Results, 134: College Station, TX (Ocean Drilling Program), 109-130. doi:10.2973/odp.proc.sr.134.008.1994

Martin-Kaye, P.H.A., 1969. A summary of the geology of the Lesser Antilles. Overseas Geol. Miner. Resour., 10(2):172-206.

Mattioli, G.S., Voight, B., Linde, A.T., Sacks, I.S., Watts, P., Widiwijayanti, C., Young, S.R., Hidayat, D., Elsworth, D., Malin, P.E., Shalev, E., Van Boskirk, E., Johnston, W., Sparks, R.S.J., Neuberg, J., Bass, V., Dunkley, P., Herd, R., Syers, T., Williams, P., and Williams, D., 2007. Unique and remarkable dilatometer measurements of pyroclastic flow-generated tsunamis. Geology, 35(1):25-28. doi:10.1130/G22931A.1

McGuire, W.J., 1996. Volcano instability: a review of contemporary themes. Geol. Soc. Spec. Publ., 110(1):1-23. doi:10.1144/GSL.SP.1996.110.01.01

Moore, J.G., Clague, D.A., Holcomb, R.T., Lipman, P.W., Normark, W.R., and Torresan, M.E., 1989. Prodigious 
submarine landslides on the Hawaiian Ridge. J. Geophys. Res., [Solid Earth], 94(B12):17465-17484. doi:10.1029/ JB094iB12p17465

Oehler, J.-F., Labazuy, P., and Lénat, J.F., 2004. Recurrence of major flank landslides during the last 2 Ma history of Reunion Island. Bull. Volcanol., 66(7):585-598. doi:10.1007/s00445-004-0341-2

Oehler, J.-F., Lénat, J.-F., and Labazuy, P., 2008. Growth and collapse of the Reunion Island volcanoes. Bull. Volcanol., 70(6):717-742. doi:10.1007/s00445-007-0163-0

Picard, M., Schneider, J.-L., and Boudon, G., 2006. Contrasting sedimentary processes along a convergent margin: the Lesser Antilles arc system. Geo-Mar. Lett., 26(6):397-410. doi:10.1007/s00367-006-0046-y

Pinel, V., and Jaupart, C., 2000. The effect of edifice load on magma ascent beneath a volcano. Philos. Trans. $R$. Soc., A, 358(1770):1515-1532. doi:10.1098/ rsta.2000.0601

Quidelleur, X., Hildebrand, A., and Samper, A., 2008. Causal link between Quaternary paleoclimatic changes and volcanic islands evolution. Geophys. Res. Lett., 35(2):L02303. doi:10.1029/2007GL031849

Reid, R.P., Carey, S.N., and Ross, D.R., 1996. Late Quaternary sedimentation in the Lesser Antilles island arc. Geol. Soc. Am. Bull., 108(1):78-100. doi:10.1130/00167606(1996)108<0078:LQSITL >2.3.CO;2

Samper, A., Quidelleur, X., Boudon, G., Le Friant, A., and Komorowski, J.C., 2008. Radiometric dating of three large-volume flank collapses in the Lesser Antilles arc. J. Volcanol. Geotherm. Res., 176(4):485-492. doi:10.1016/ j.jvolgeores.2008.04.018

Samper, A., Quidelleur, X., Lahitte, P., and Mollex, D., 2007. Timing of effusive volcanism and collapse events within an oceanic arc island: Basse-Terre, Guadeloupe archipelago (Lesser Antilles arc). Earth Planet. Sci. Lett., 258(1-2):175-191. doi:10.1016/j.epsl.2007.03.030

Schmincke, H.-U., and Sumita, M., 1998. Volcanic evolution of Gran Canaria reconstructed from apron sediments: synthesis of VICAP project drilling. In Weaver, P.P.E., Schmincke, H.-U., Firth, J.V., and Duffield, W. (Eds.), Proc. ODP, Sci. Results, 157: College Station, TX (Ocean Drilling Program), 443-469. doi:10.2973/ odp.proc.sr.157.135.1998

Schneider, J.-L., Gérard, M., Schmincke, H.-U., Weaver, P.P.E., Firth, J., Baraza, J., Bristow, J.F., Brunner, C., Carey, S.N., Coakley, B., Fuller, M., Funk, T., Goldstrand, P., Herr, B., Hood, J., Howe, R., Jarvis, I., Lebreiro, S., Lindblom, S., Lykke-Andersen, H., Maniscalco, R., Rothwell, G., Sblendorio-Levy, J., Sumita, M., Taniguchi, H., $\mathrm{Tu}$, P., and Wallace, P., 1997. Du volcan au sédiment: la dynamique du talus volcanoclastique sous-marin de Gran Canaria, Canaries (Atlantique oriental, Leg ODP 157). C. R. Acad. Sci., Ser. IIa: Sci. Terre Planetes, 324(11):891-898. doi:10.1016/S1251-8050(97)82502-5

Schneider, J.-L., Pérez Torrado, F.J., Torrente, D.G., Wassmer, P., del Carmen Cabrera Santana, M., and Carracedo, J.C., 2004. Sedimentary signatures of the entrance of coarse-grained volcaniclastic flows into the sea: the example of the breccia units of the Las Palmas detritic formation (Mio-Pliocene, Gran Canaria, eastern
Atlantic, Spain). J. Volcanol. Geotherm. Res., 138(34):295-323. doi:10.1016/j.jvolgeores.2004.07.007

Shea, T., van Wyk de Vries, B., and Pilato, M., 2008. Emplacement mechanisms of contrasting debris avalanches at Volcán Mombacho (Nicaragua), provided by structural and facies analysis. Bull. Volcanol., 70(8):899921. doi:10.1007/s00445-007-0177-7

Sigurdsson, H., Sparks, R.S.J., Carey, S.N., and Huang, T.C., 1980. Volcanogenic sedimentation in the Lesser Antilles arc. J. Geol., 88(5):523-540. doi:10.1086/628542

Smith, W.H.F., and Sandwell, D.T., 1997. Global seafloor topography from satellite altimetry and ship depth soundings. Science, 277(5334):1956-1962. doi:10.1126/ science.277.5334.1956

Sparks, R.S.J., Minshull, T., Malin, P.E., Paulatto, M., Shalev, E., Voight, B., et al., 2008. SEA-CALIPSO volcano imaging experiment on Montserrat, Part 2. Sea operations, OBS deployments, and images from streamers and offshore/onshore stations [IAVCEI 2008 General Assembly, Reykjavík, Iceland, 17-22 August 2008].

Sparks, R.S.J., Sigurdsson, H., and Carey, S.N., 1980a. The entrance of pyroclastic flows into the sea, I. Oceanographic and geologic evidence from Dominica, Lesser Antilles. J. Volcanol. Geotherm. Res., 7(1-2):87-96. doi:10.1016/0377-0273(80)90021-9

Sparks, R.S.J., Sigurdsson, H., and Carey, S.N., 1980b. The entrance of pyroclastic flows into the sea, II. Theoretical considerations on subaqueous emplacement and welding. J. Volcanol. Geotherm. Res., 7(1-2):97-105. doi:10.1016/0377-0273(80)90022-0

Takarada, S., Ui, T., and Yamamoto, Y., 1999. Depositional features and transportation mechanism of valley-filling Iwasegawa and Kaida debris avalanches, Japan. Bull. Volcanol., 60(7):508-522. doi:10.1007/s004450050248

Trofimovs, J., Amy, L., Boudon, G., Deplus, C., Doyle, E., Fournier, N., Hart, M.B., Komorowski, J.C., Le Friant, A., Lock, E.J., Pudsey, C., Ryan, G., Sparks, R.S.J., and Talling, P.J., 2006. Submarine pyroclastic deposits formed at the Soufrière Hills Volcano, Montserrat (1995-2003): what happens when pyroclastic flows enter the ocean? Geology, 34(7):549-552. doi:10.1130/ G22424.1

Trofimovs, J., Fisher, J.K., Macdonald, H.A., Talling, P.J., Sparks, R.S.J., Hart, M.B., Smart, C.W., Boudon, G., Deplus, C., Komorowski, J.-C., Le Friant, A., Moreton, S.G., and Leng, M.J., 2010. Evidence for carbonate platform failure during rapid sea-level rise: ca. 14,000 year old bioclastic flow deposits in the Lesser Antilles. Sedimentology, 57(3):735-759. doi:10.1111/j.13653091.2009.01117.x

Trofimovs, J., Foster, C., Sparks, R.S.J., Loughlin, S., Le Friant, A., Deplus, C., Porritt, L., Christopher, T., Luckett, R., Talling, P.J., Palmer, M.R., and Le Bas, T., 2012. Submarine pyroclastic deposits formed during the 20th May 2006 dome collapse of the Soufrière Hills Volcano, Montserrat. Bull. Volcanol., 74(2):391-405. doi:10.1007/ s00445-011-0533-5

Trofimovs, J., Sparks, R.S.J., and Talling, P.J., 2008. Anatomy of a submarine pyroclastic flow and associated turbidity current: July 2003 dome collapse, Soufrière 
Hills Volcano, Montserrat, West Indies. Sedimentology, 55(3):617-634. doi:10.1111/j.1365-3091.2007.00914.X

Urgeles, R., Canals, M., Baraza, J., Alonso, B., and Masson, D., 1997. The most recent megalandslides of the Canary Islands: El Golfo debris avalanche and Canary debris flow, west El Hierro Island. J. Geophys. Res., [Solid Earth], 102(B9):20305-20323. doi:10.1029/97JB00649

Utzmann, A., Hansteen, T., and Schmincke, H.-U., 2002. Trace element mobility during subseafloor alteration of basaltic glass from Ocean Drilling Program Site 953 (off Gran Canaria). Int. J. Earth Sci., 91(4):661-679. doi:10.1007/s00531-001-0247-6

Vennat, J., 2004. Téphrochronologie et études des dépôts pyroclastiques à terre des éruptions récentes de la Soufrière de Guadeloupe [M.S. thesis]. Institut de Physique du Globe de Paris (IPGP), Univ. Paris VII.

Voight, B. (Ed.), 1978. Rockslides and Avalanches, 1: Natural Phenomena. Dev. Geotech. Eng., 14A.

Voight, B., 1981. Timescale for the first moments of the May 18 eruption. In Lipman, P.W., and Mullineaux, D.R. (Eds.), The 1980 Eruptions of Mount St. Helens. U. S. Geol. Surv. Prof. Pap., 1250:69-86.

Voight, B., 2000. Structural stability of andesite volcanoes and lava domes. Philos. Trans. R. Soc., A, 358(1770):1663-1703. doi:10.1098/rsta.2000.0609

Voight, B., and Elsworth, D., 1997. Failure of volcano slopes. Géotechnique, 47(1):1-31. doi:10.1680/ geot.1997.47.1.1

Voight, B., Komorowski, J.-C., Norton, G.E., Belousov, A.B., Belousova, M., Boudon, G., Francis, P.W., Franz, W., Heinrich, P., Sparks, R.S.J., and Young, S.R., 2002. The 26 December (Boxing Day) 1997 sector collapse and debris avalanche at Soufrière Hills Volcano, Montserrat. Mem.-Geol. Soc. London, 21(1):363-407. doi:10.1144/ GSL.MEM.2002.021.01.17

Voight, B., Shalev, E., Hidayat, D., Kenedi, K.L., Brown, L., Minshull, T., Sparks, R.S.J., Snelson, C., Mattioli, G.S., Miller, V., Widiwijayanti, C., Stewart, R., Carothers, L., Johnson, M., Zamora, W., Herd, R., Malin, P.E., Ammon, C., Elsworth, D., Saldana, S., Paulatto, M., De Angelis, S., Byerly, K., Kiddle, E., Bass, V., Belousov, A., Chen, C., Clarke, A.B., Christensen, B., Christopher, T., CustanceBaker, A., Hammond, J., Hards, V., Jeffcoat, K., Lee, A., Linde, A., Loughlin, S., Malin, R., Sacks, S., Smith, D., Strutt, M., Syers, T., Taron, J., Walton, J., and Winston, J., 2008. The SEA-CALIPSO volcano imaging experiment on Montserrat, Part 1. Onshore seismometer deployments, tomography, and images from onshore stations
[IAVCEI 2008 General Assembly, Reykjavík, Iceland, 1722 August 2008].

Voight, B., and Sousa, J., 1994. Lessons from Ontake-san: a comparative analysis of debris avalanche dynamics. Eng. Geol., 38(3-4):261-297. doi:10.1016/00137952(94)90042-6

Wadge, G., 1984. Comparison of volcanic production rates and subduction rates in the Lesser Antilles and Central America. Geology, 12(9):555-558. doi:10.1130/ 0091-7613(1984)12<555:COVPRA > 2.0.CO;2

Wadge, G., 1986. The dykes and structural setting of the volcanic front in the Lesser Antilles island arc. Bull. Volcanol., 48(6):349-372. doi:10.1007/BF01074466

Wadge, G., Herd, R., Ryan, G., Calder, E.S., and Komorowski, J.-C., 2010. Lava production at Soufrière Hills Volcano, Montserrat: 1995-2009. Geophys. Res. Lett., 37:L00E03. doi:10.1029/2009GL041466

Watt, S.F.L., Talling, P.J., Vardy, M.E., Heller, V., Hühnerbach, V., Urlaub, M., Sarkar, S., Masson, D.G., Henstock, T.J., Minshull, T.A., Paulatto, M., Le Friant, A., Lebas, E., Berndt, C., Crutchley, G.J., Karstens, J., Stinton, A.J., and Maeno, F., 2012. Combinations of volcanic-flank and seafloor-sediment failure offshore Montserrat, and their implications for tsunami generation. Earth Planet. Sci. Lett., 319-320:228-240. doi:10.1016/j.epsl.2011.11.032

Watts, A.B., and Masson, D.G., 1995. A giant landslide on the north flank of Tenerife, Canary Islands. J. Geophys. Res., [Solid Earth], 100(B12):24487-24498. doi:10.1029/ 95JB02630

Westbrook, G.K., and McCann, W.R., 1986. Subduction of Atlantic lithosphere beneath the Caribbean. In Vogt, P.R., and Tucholke, B.E. (Eds.), The Geology of North America (Vol. M): The Western North Atlantic Region: Boulder, CO (Geol. Soc. Am.), 341-350.

Whitham, A.G., 1989. The behaviour of subaerially produced pyroclastic flows in a subaqueous environment: evidence from the Roseau eruption, Dominica, West Indies. Mar. Geol., 86(1):27-40. doi:10.1016/00253227(89)90016-9

Wynn, R.B., and Masson, D.G., 2003. Canary Islands landslides and tsunami generation: can we use turbidite deposits to interpret landslide processes? In Locat, J., and Mienert, J. (Eds.), Submarine Mass Movements and Their Consequences. Adv. Nat. Technol. Hazards Res., 19(2):325-332. doi:10.1007/978-94-010-0093-2_36

Publication: 17 August 2013 MS 340-101 
Figure F1. The Lesser Antilles arc. Predicted bathymetry from Smith and Sandwell (1997).

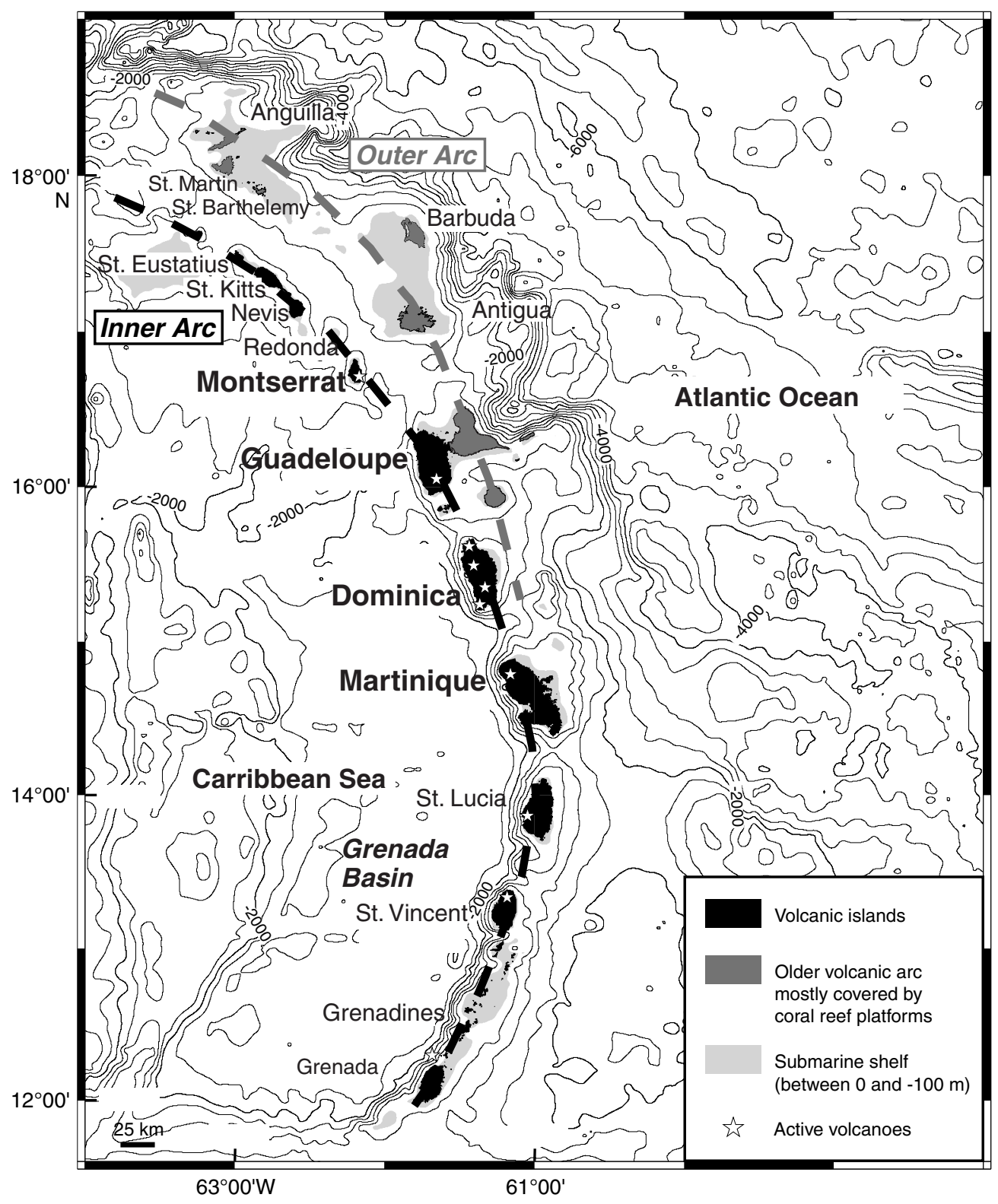


Figure F2. Montserrat. Shaded image of topography-bathymetry, extent of chaotic units (interpreted as debris avalanche deposits), and drill sites, Expedition 340.

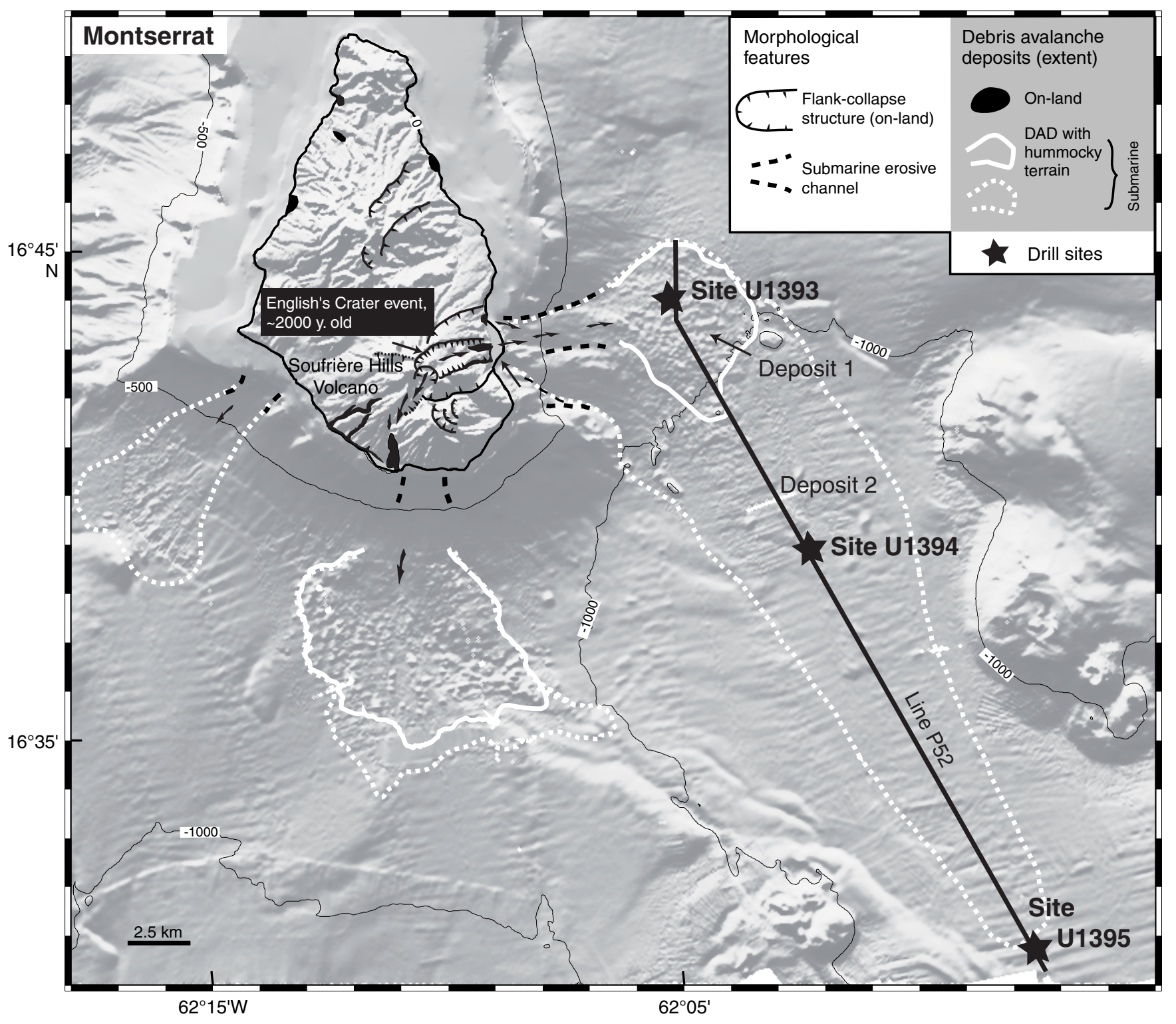


Figure F3. Extent of chaotic units (interpreted as debris avalanche deposits) superimposed on swath bathymetry and drill sites, Expedition 340.

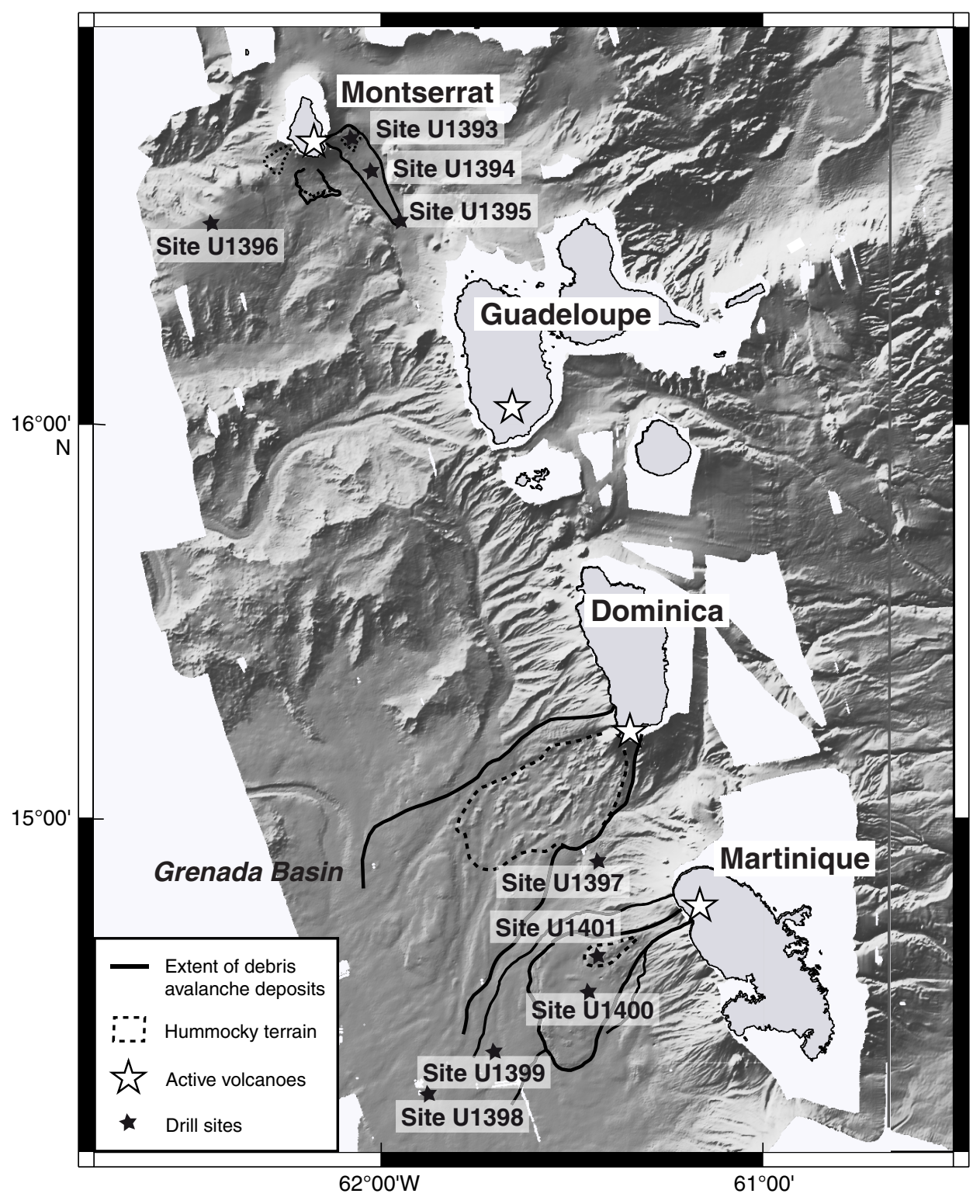


Figure F4. Dominica. Shaded image of topography-bathymetry, extent of chaotic units (interpreted as debris avalanche deposits), and drill sites, Expedition 340.

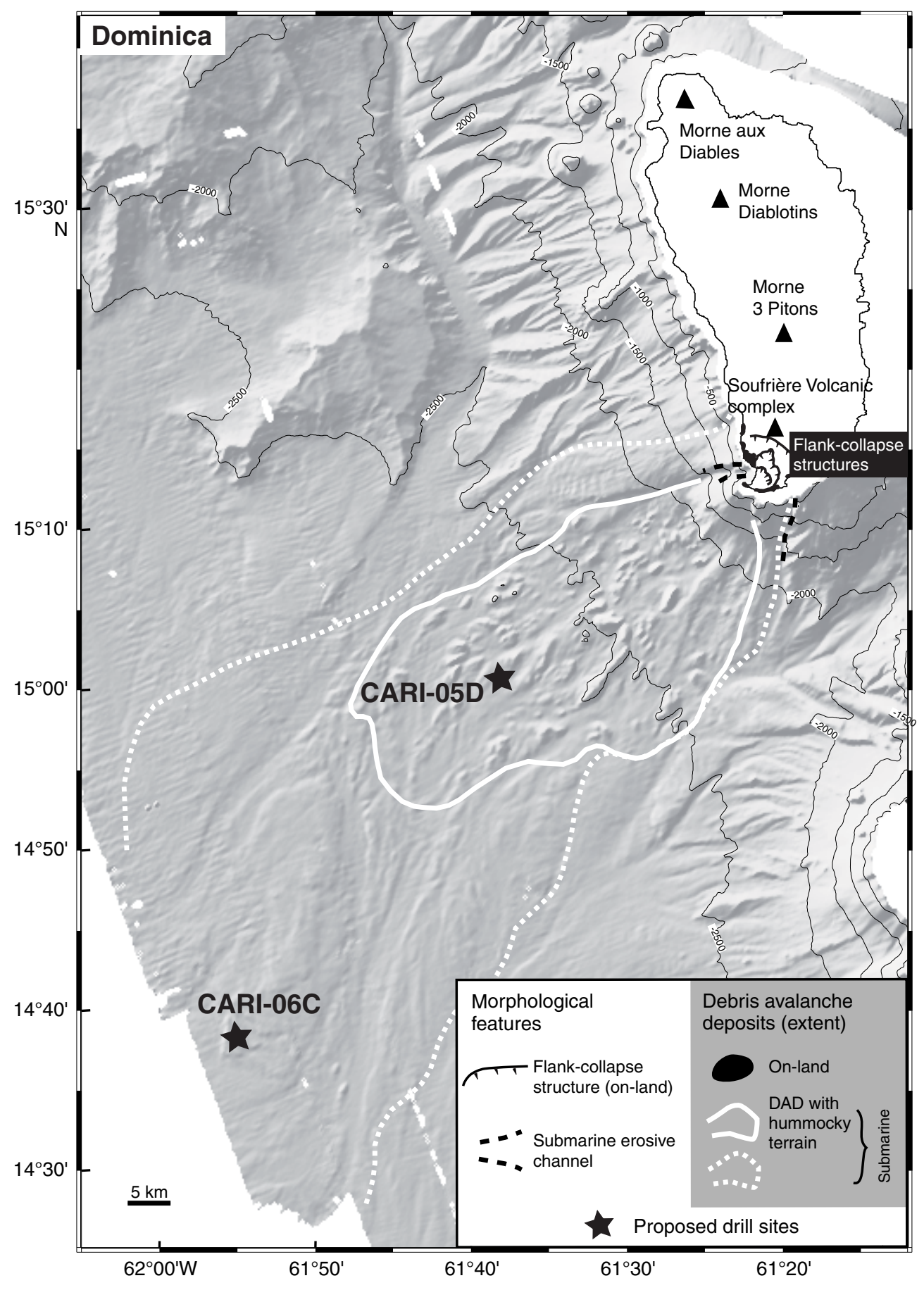


Figure F5. A. Hole U1393A summary. MAJ = major, cps = counts per second. B. Graphic lithology key.

A

Hole U1393A

Core Lith. Graphic

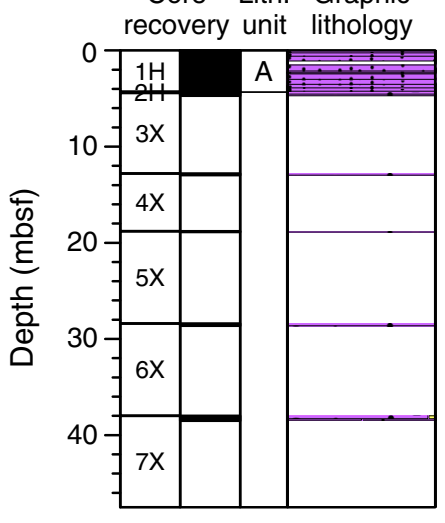

MAJ lith grain size

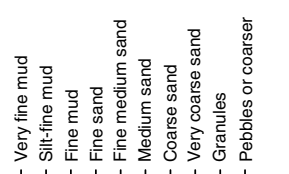

Magnetic usceptibility

(SI)

-

Density
$\left(\mathrm{g} / \mathrm{cm}^{3}\right)$

Natural

gamma

radiation

(cps)
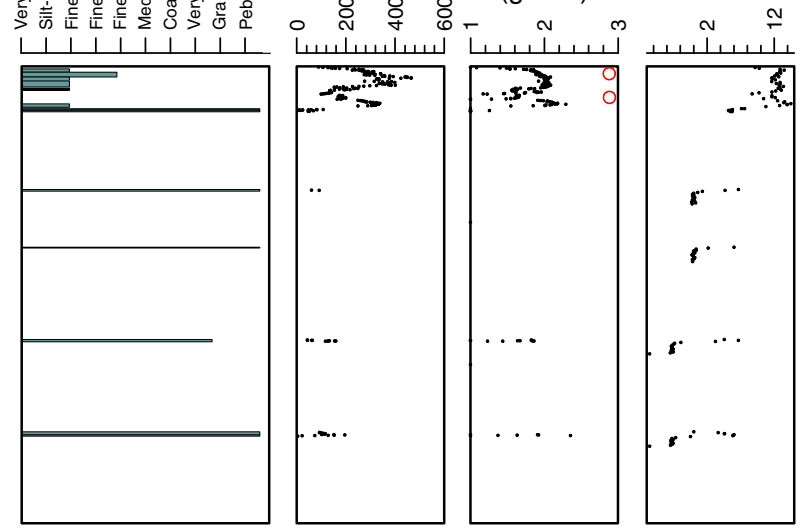

B

\begin{tabular}{|c|c|}
\hline $\begin{array}{l}\frac{T}{T} \frac{1}{T} \frac{\perp}{T} \frac{\perp}{T}=\frac{1}{T} \\
\perp\end{array}$ & $\begin{array}{l}\text { Carbonate ooze/ } \\
\text { Lime mud }\end{array}$ \\
\hline & $\begin{array}{l}\text { Calcareous } \\
\text { sand }\end{array}$ \\
\hline $\begin{array}{l}\top \\
\perp \\
\top\end{array} \frac{1}{\top} \stackrel{\perp}{\top}=\frac{\perp}{\top}$ & $\begin{array}{l}\text { Lime } \\
\text { sandstone }\end{array}$ \\
\hline & $\begin{array}{l}\text { Calcareous } \\
\text { sand }\end{array}$ \\
\hline & $\begin{array}{l}\text { Lime } \\
\text { gravel }\end{array}$ \\
\hline
\end{tabular}

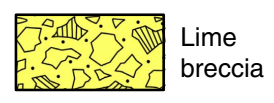

$\because \because \because \because:$ Lime
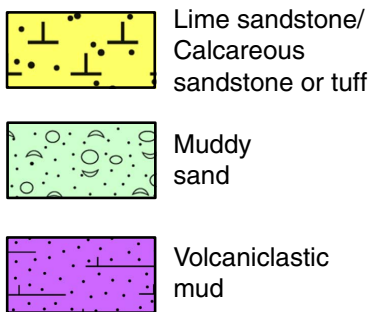
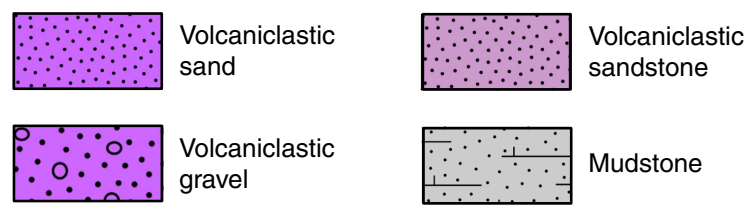

Mudstone
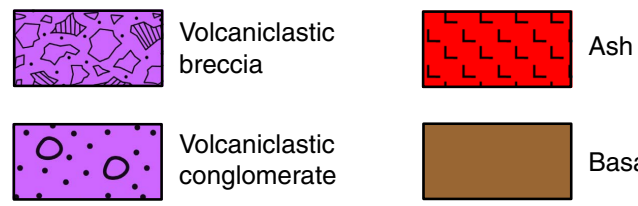

Basalt

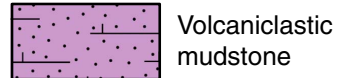


Figure F6. Hole U1394A summary. MAJ = major, cps = counts per second. See Figure F5B for graphic lithology key.

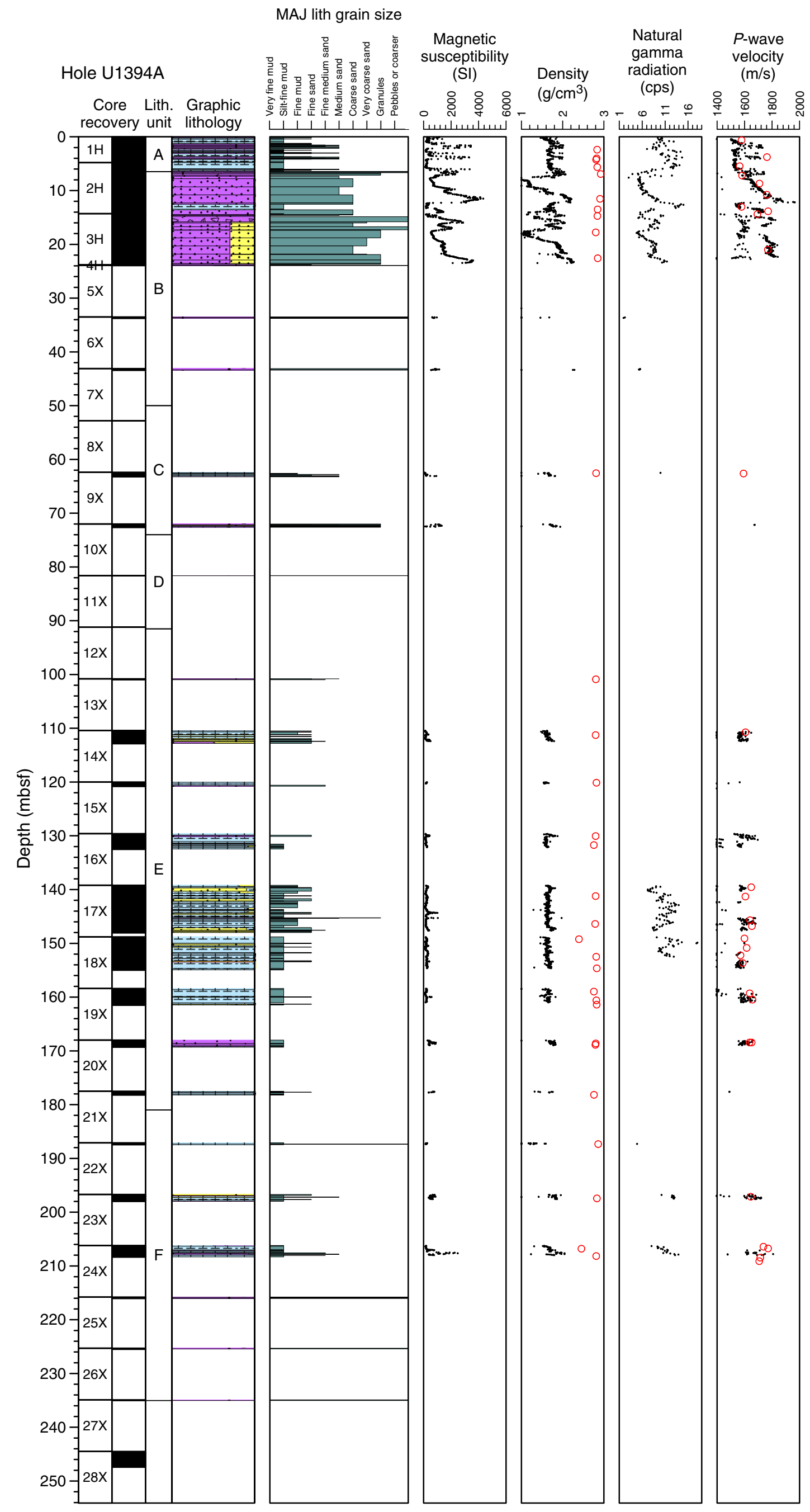


Figure F7. Hole U1394B summary. MAJ = major, $\mathrm{cps}$ = counts per second. See Figure F5B for graphic lithology key.

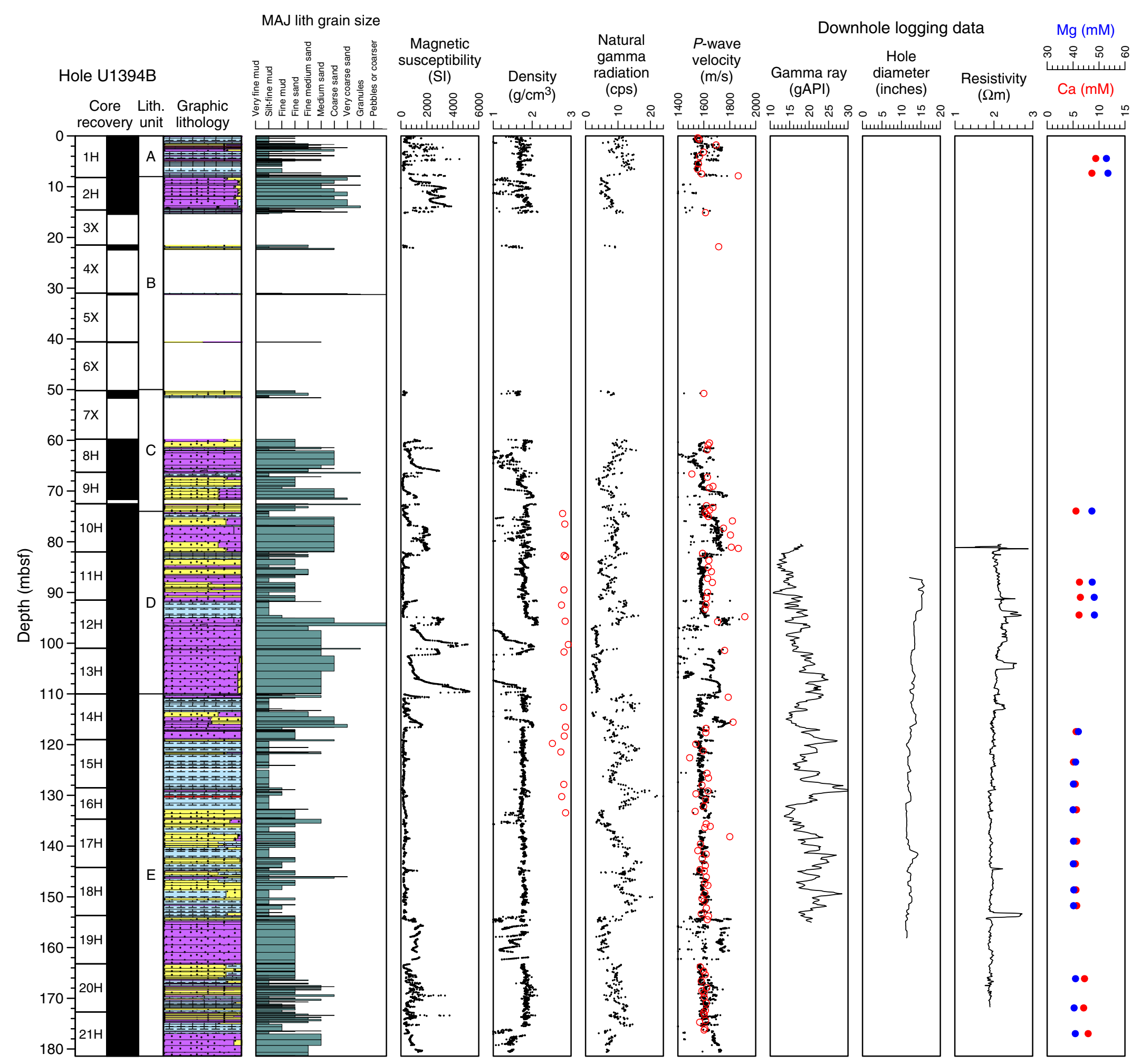


Figure F8. Hole U1395A summary. MAJ = major, cps = counts per second. See Figure F5B for graphic lithology key. Ages are based on correlation with the GPTS of Cande and Kent (1995).

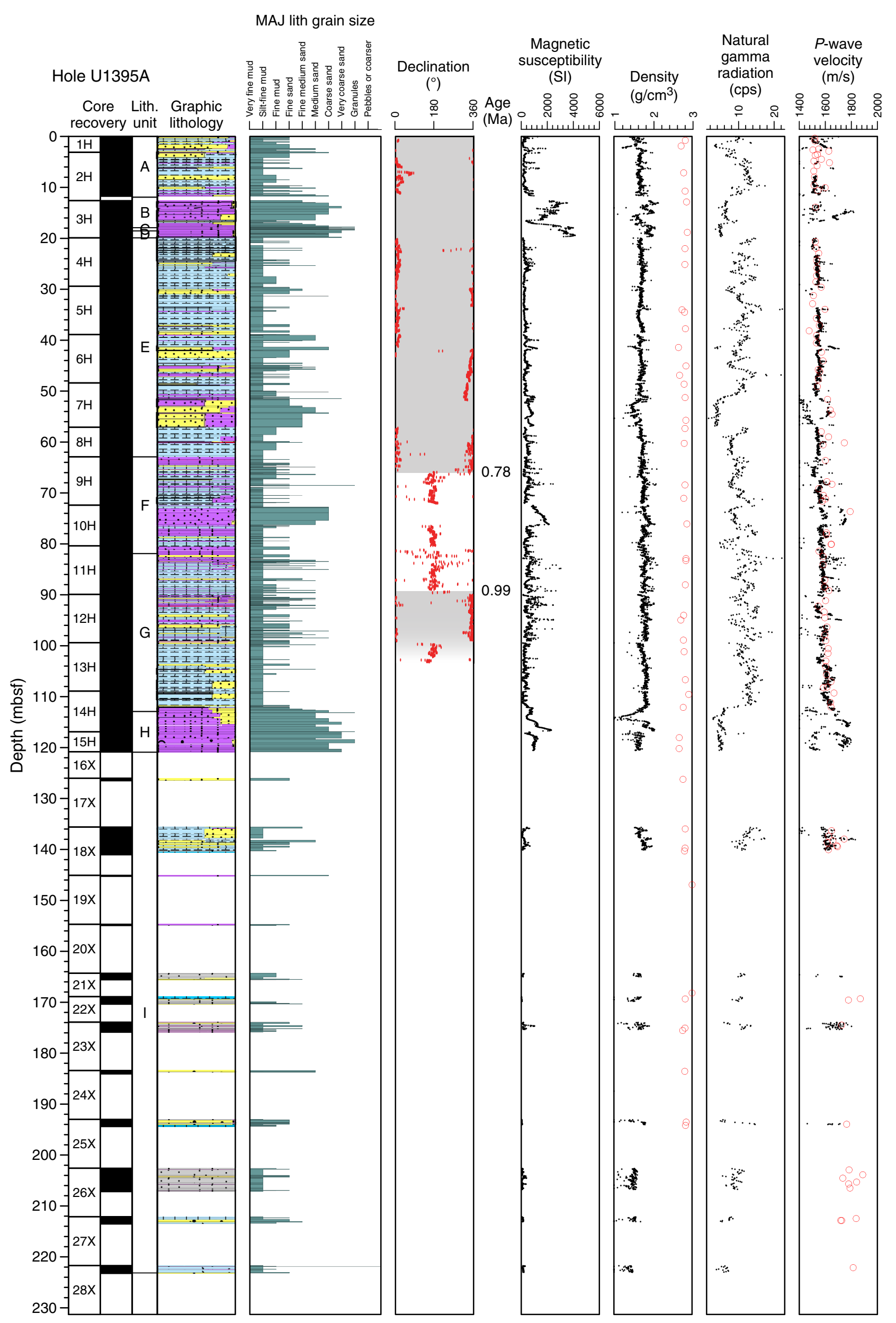


Figure F9. Hole U1395B summary. MAJ = major, cps = counts per second. See Figure F5B for graphic lithology key. Ages are based on correlation with the GPTS of Cande and Kent (1995).

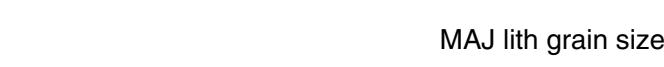

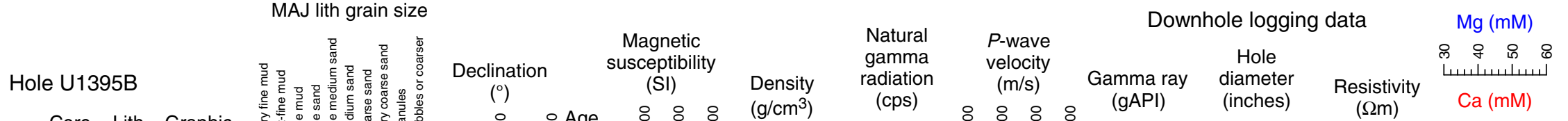

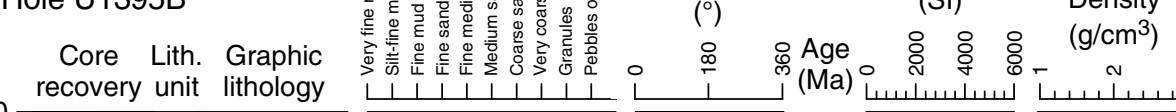

(cPs) 8 \& 8 : 8 (gAPI) $(\Omega \mathrm{m})$
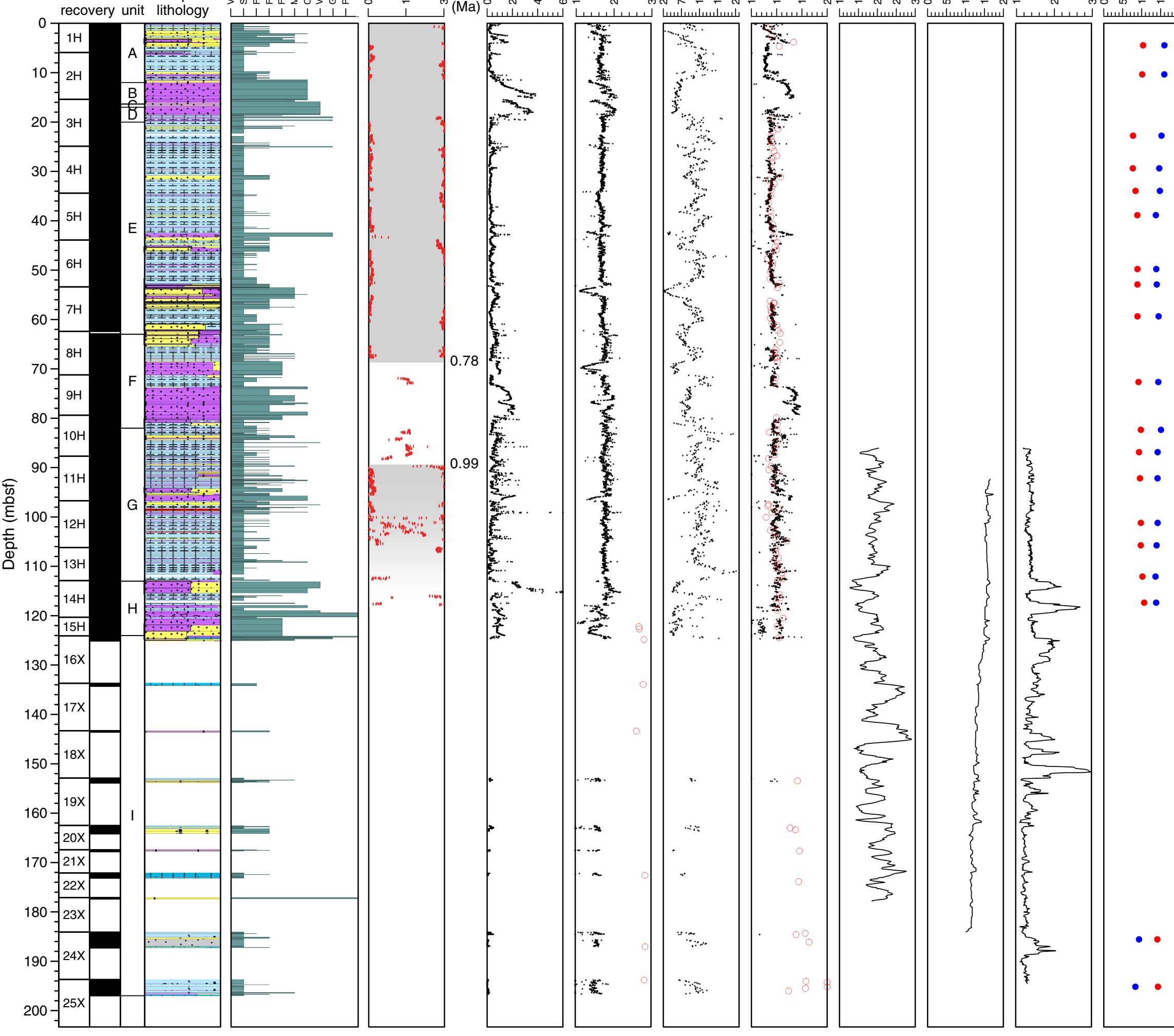

$\because$

$\because$

$::$

-

-

$\cdots$

$\because$

$\because$

.

$\because$ 
Figure F10. Site U1396 summary. MAJ = major, cps = counts per second. See Figure F5B for graphic lithology key. Ages are based on correlation with the GPTS of Cande and Kent (1995).
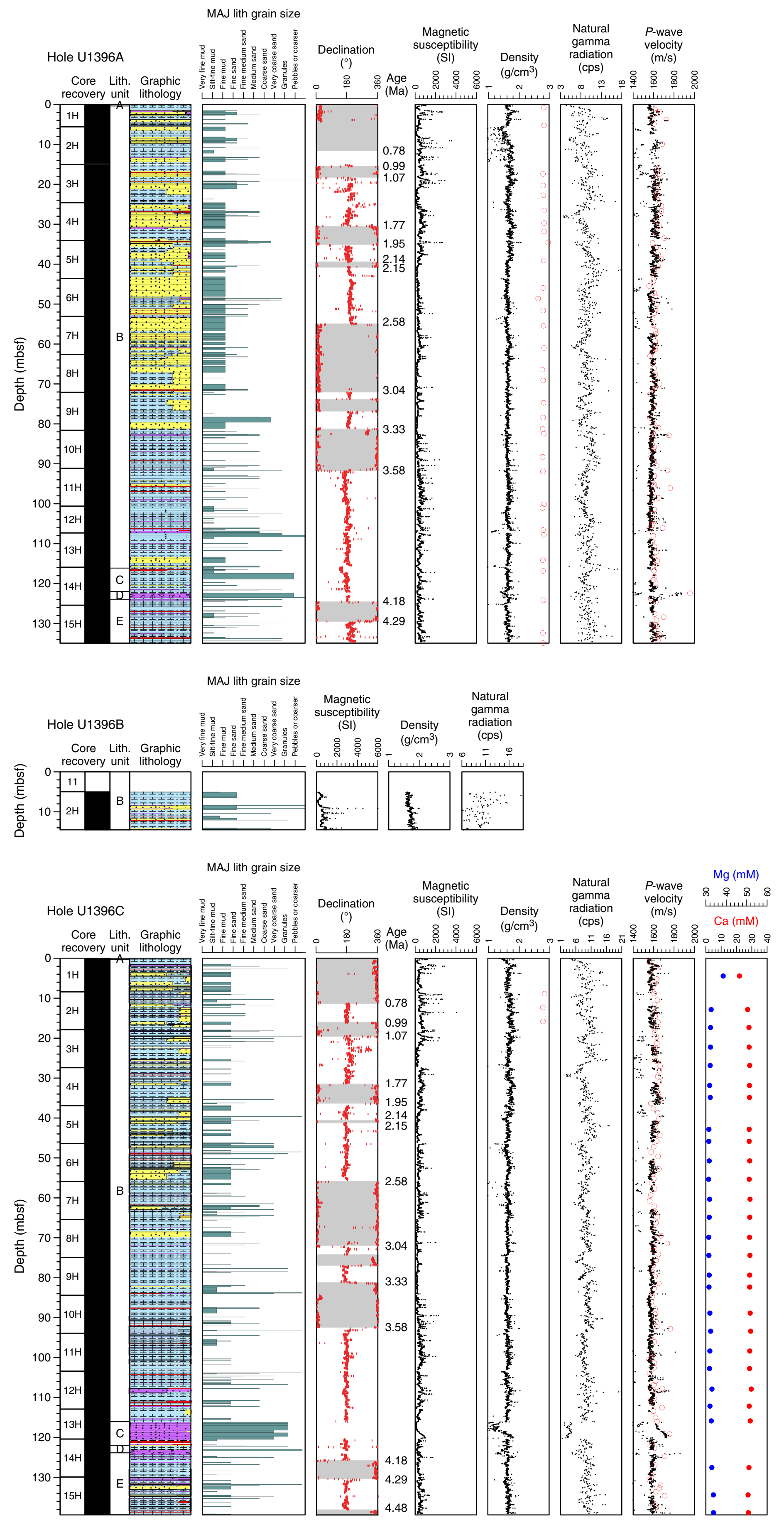
Figure F11. Martinique. Shaded image of topography and bathymetry with flank-collapse structures on shore and the extent of the submarine chaotic units (interpreted as debris avalanche deposits) (Le Friant et al., 2003a).

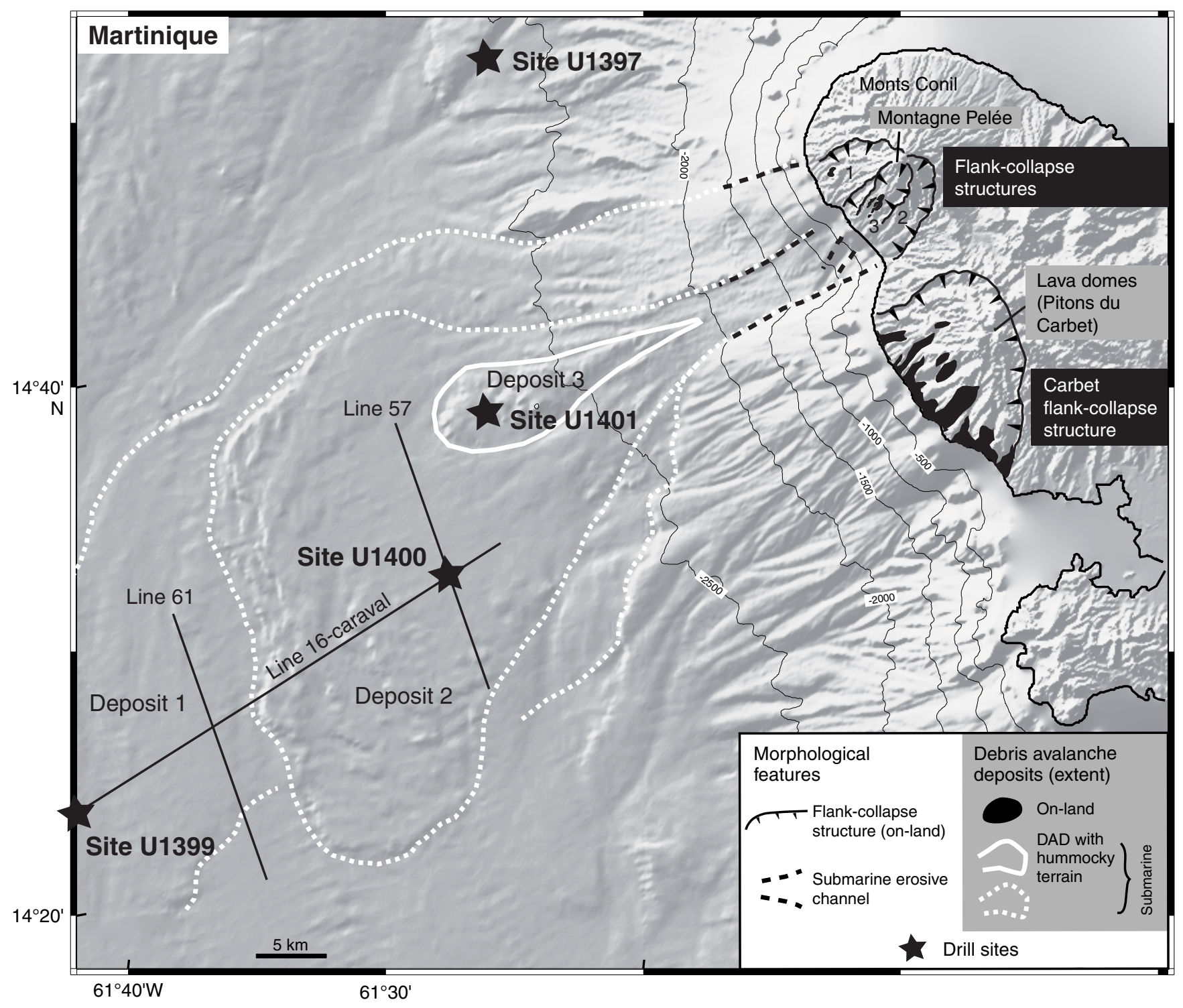


Figure F12. Hole U1397A summary. MAJ = major, cps = counts per second. See Figure F5B for graphic lithology key.

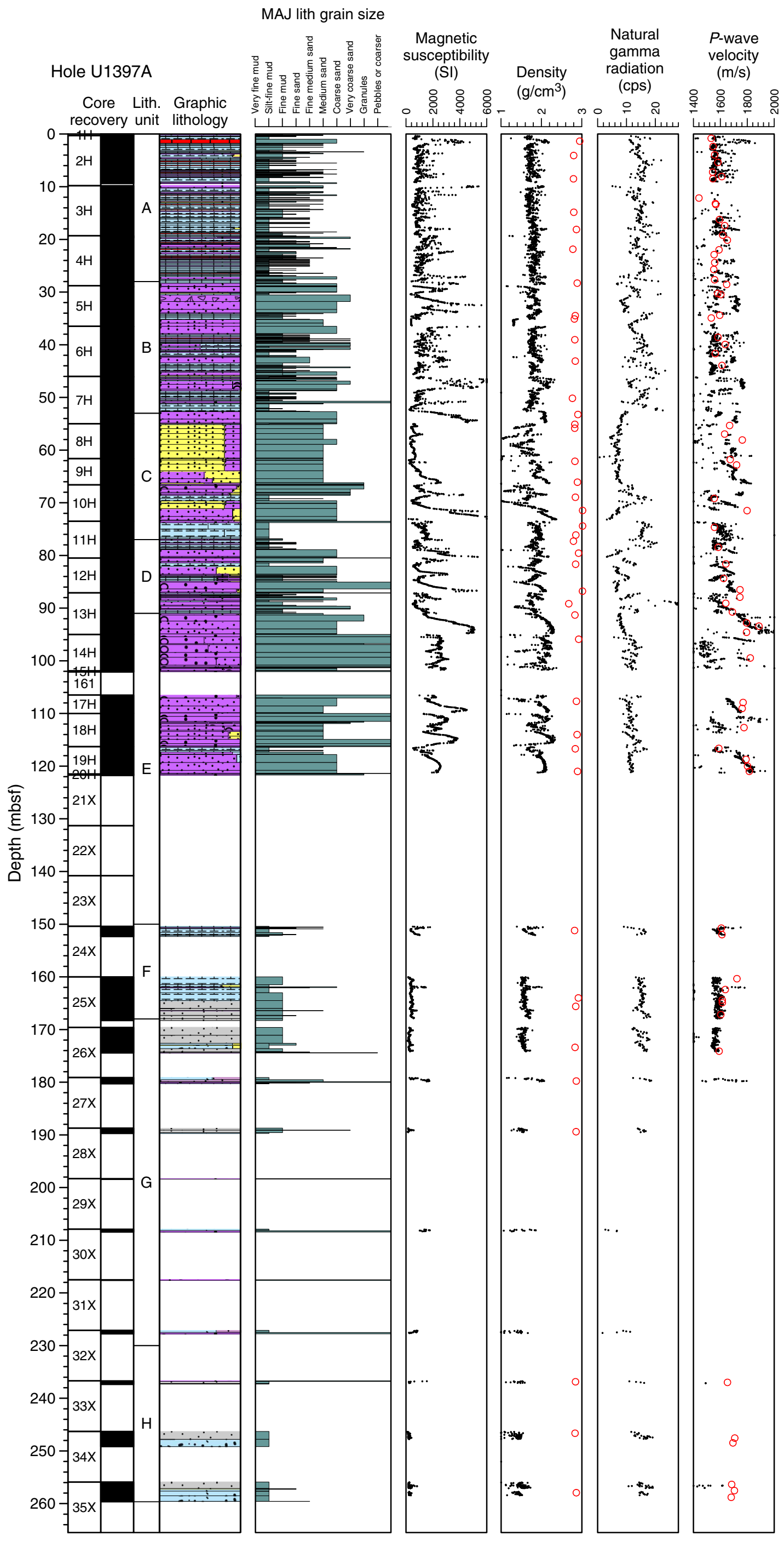


Figure F13. Hole U1397B summary. MAJ = major, cps = counts per second. See Figure F5B for graphic lithology key.

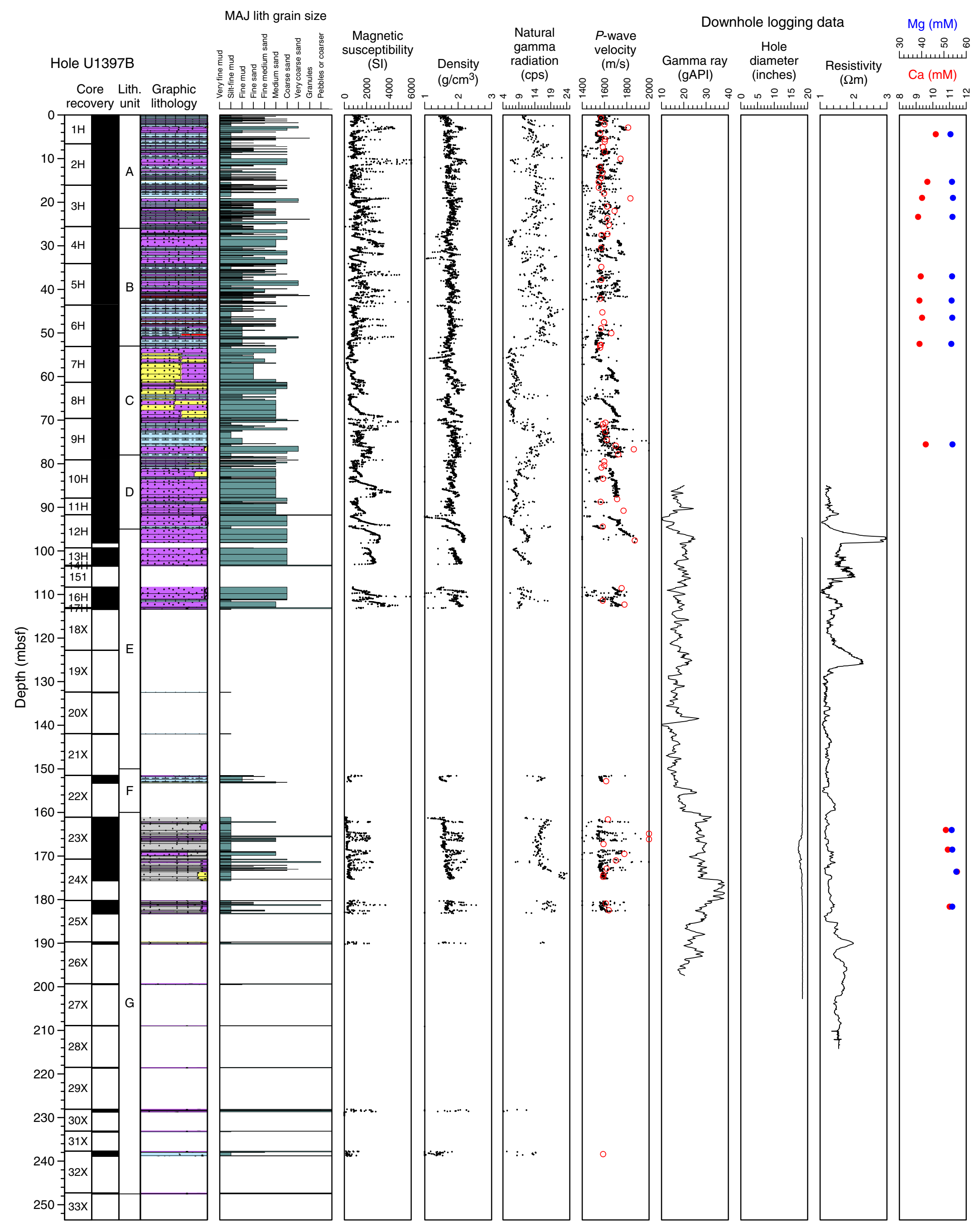


Figure F14. Hole U1398A summary. MAJ = major, cps = counts per second. See Figure F5B for graphic lithology key.

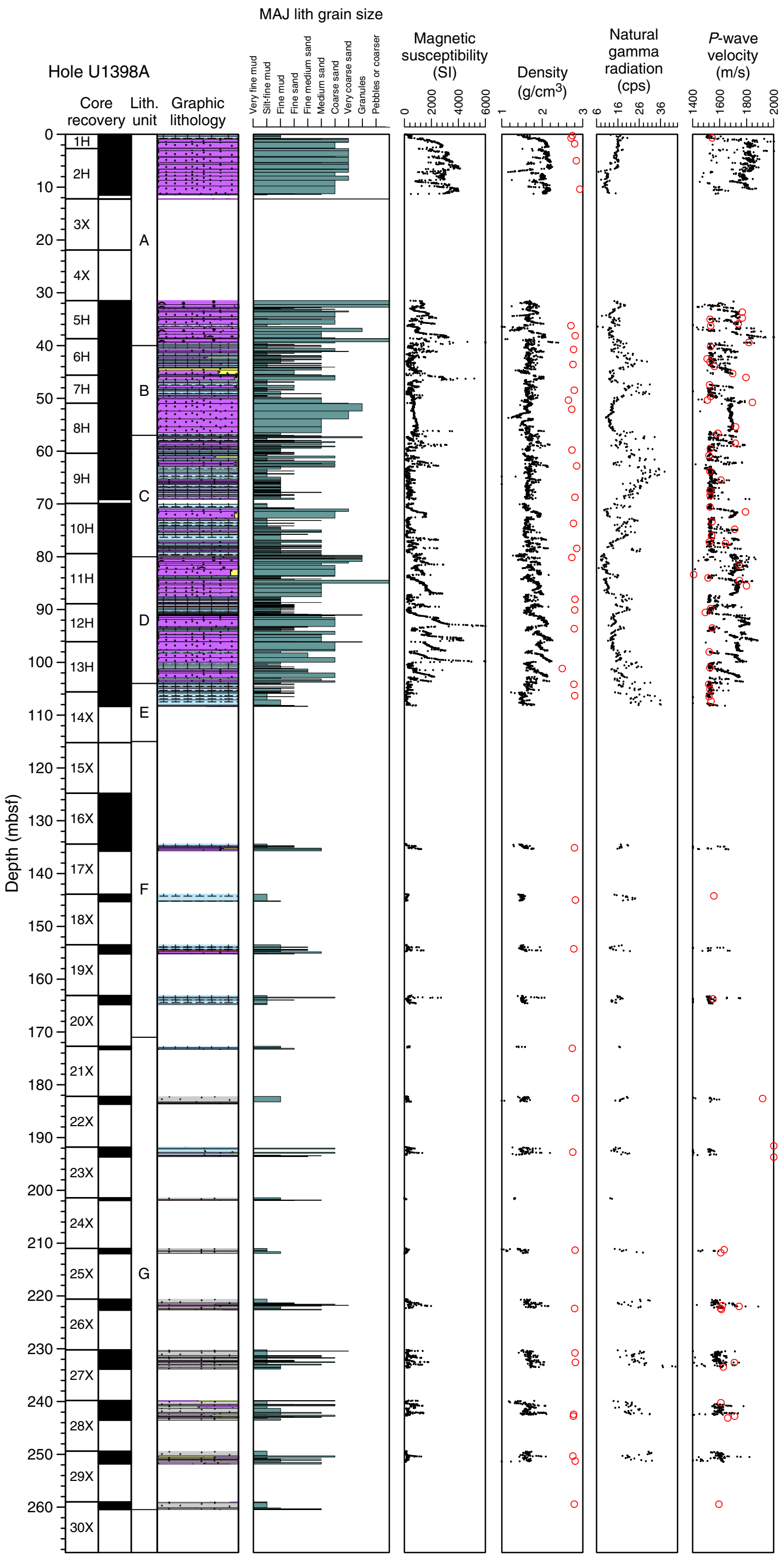


Figure F15. Hole U1398B summary. MAJ = major, cps = counts per second. See Figure F5B for graphic lithology key.

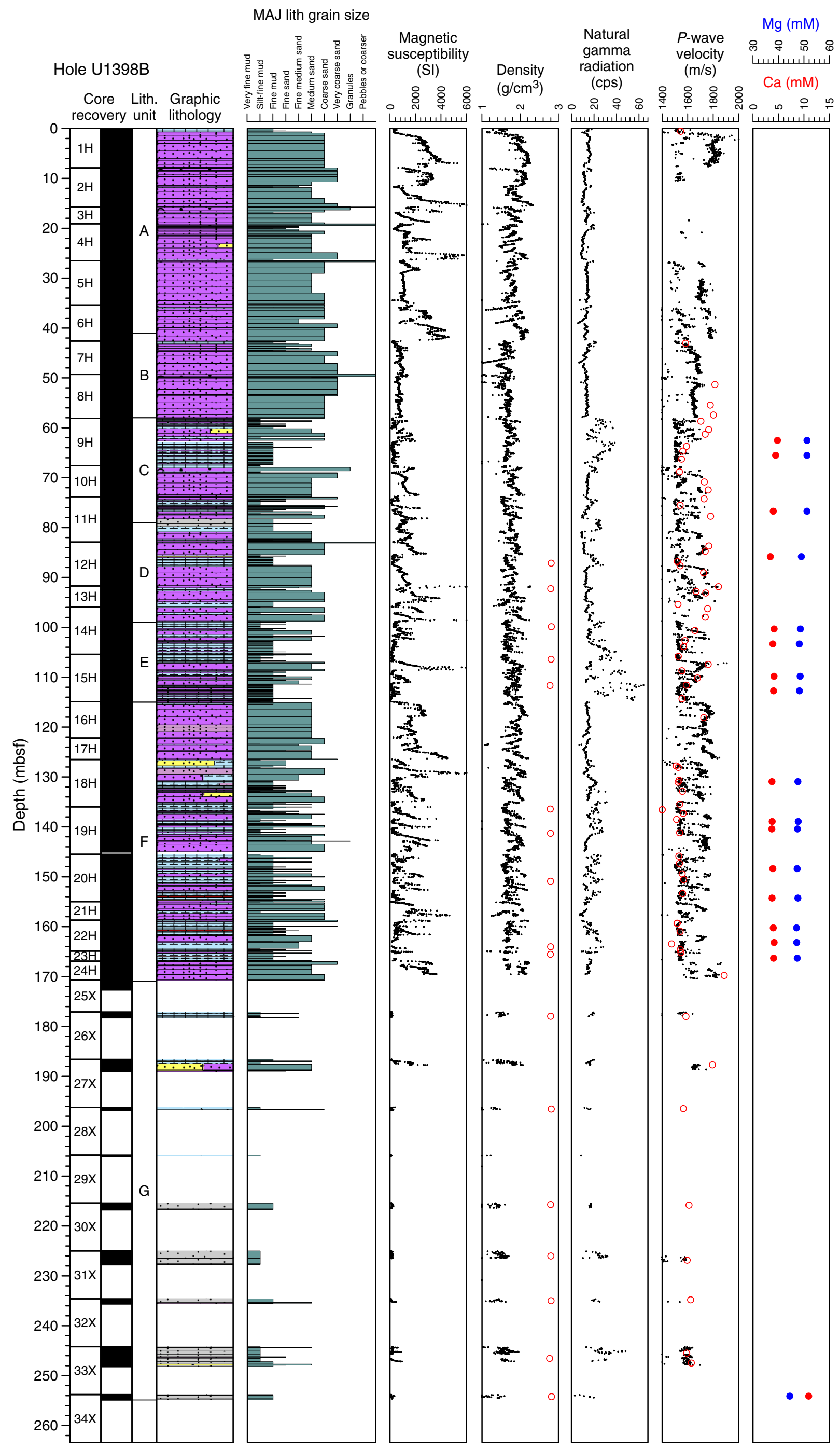


Figure F16. Hole U1399A summary. MAJ = major, cps = counts per second. See Figure F5B for graphic lithology key.

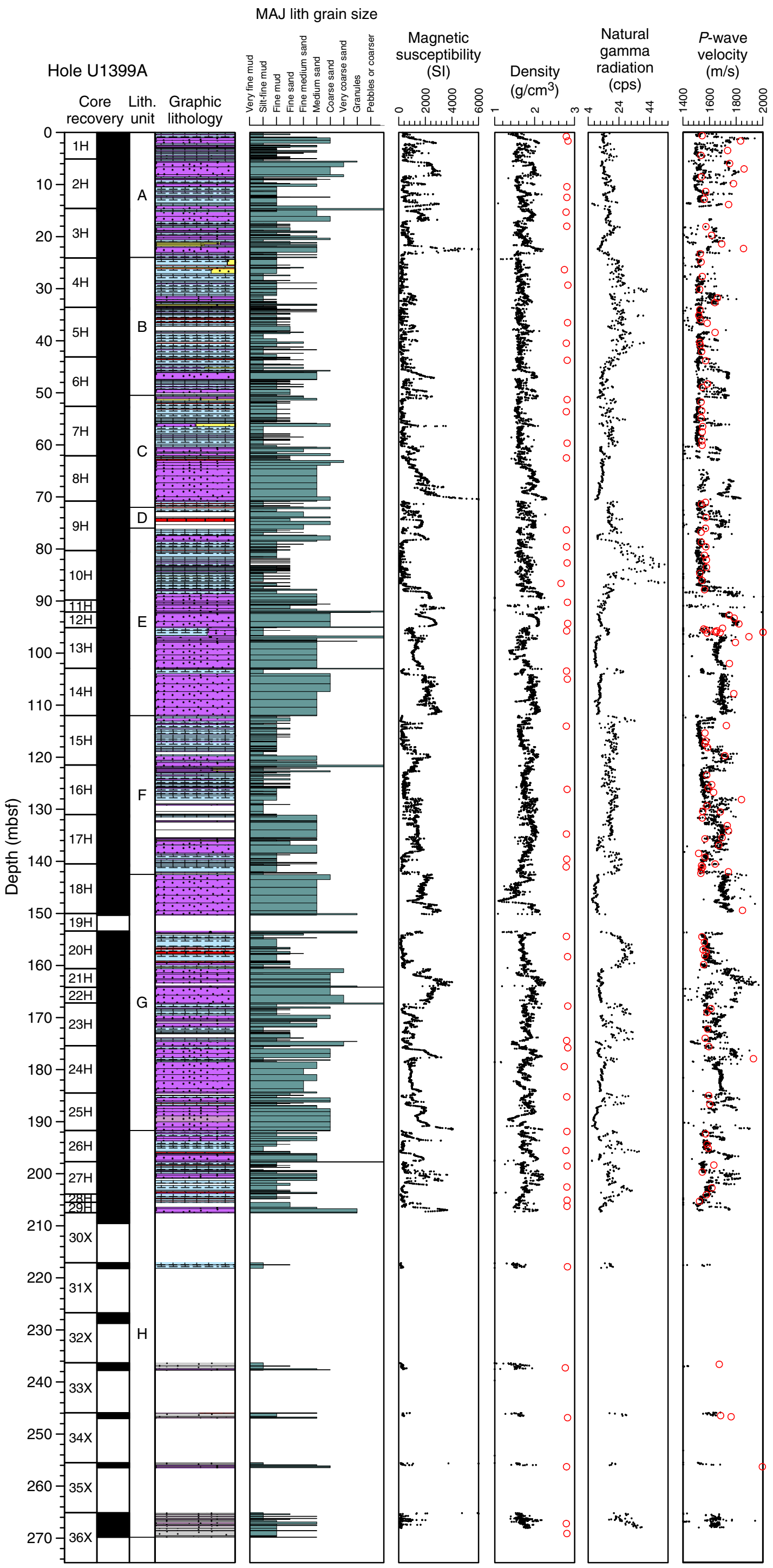


Figure F17. Hole U1399B summary. MAJ = major, $c p s=$ counts per second. See Figure F5B for graphic lithology key.

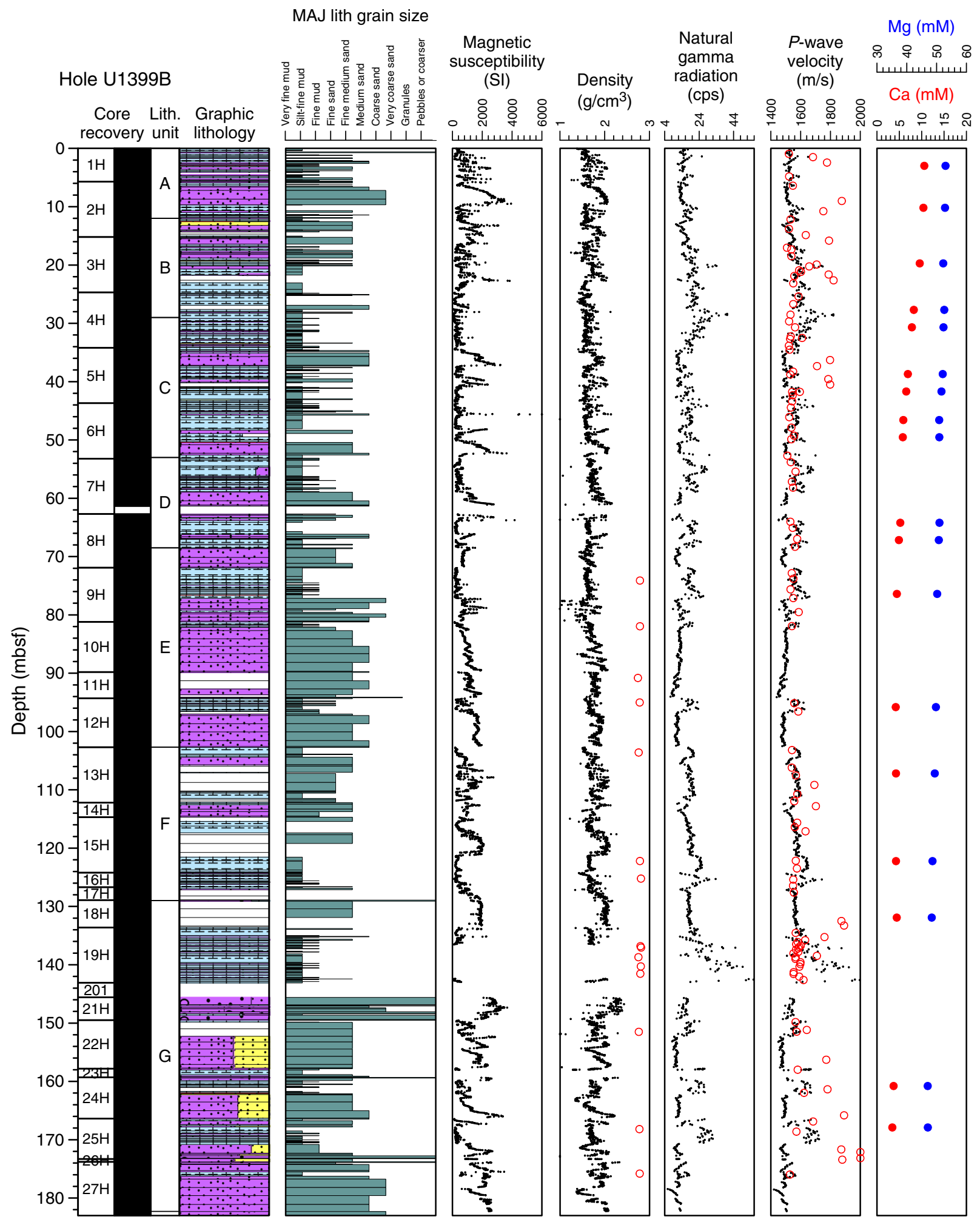


Figure F18. Hole U1399C logging summary.

Hole U1399C

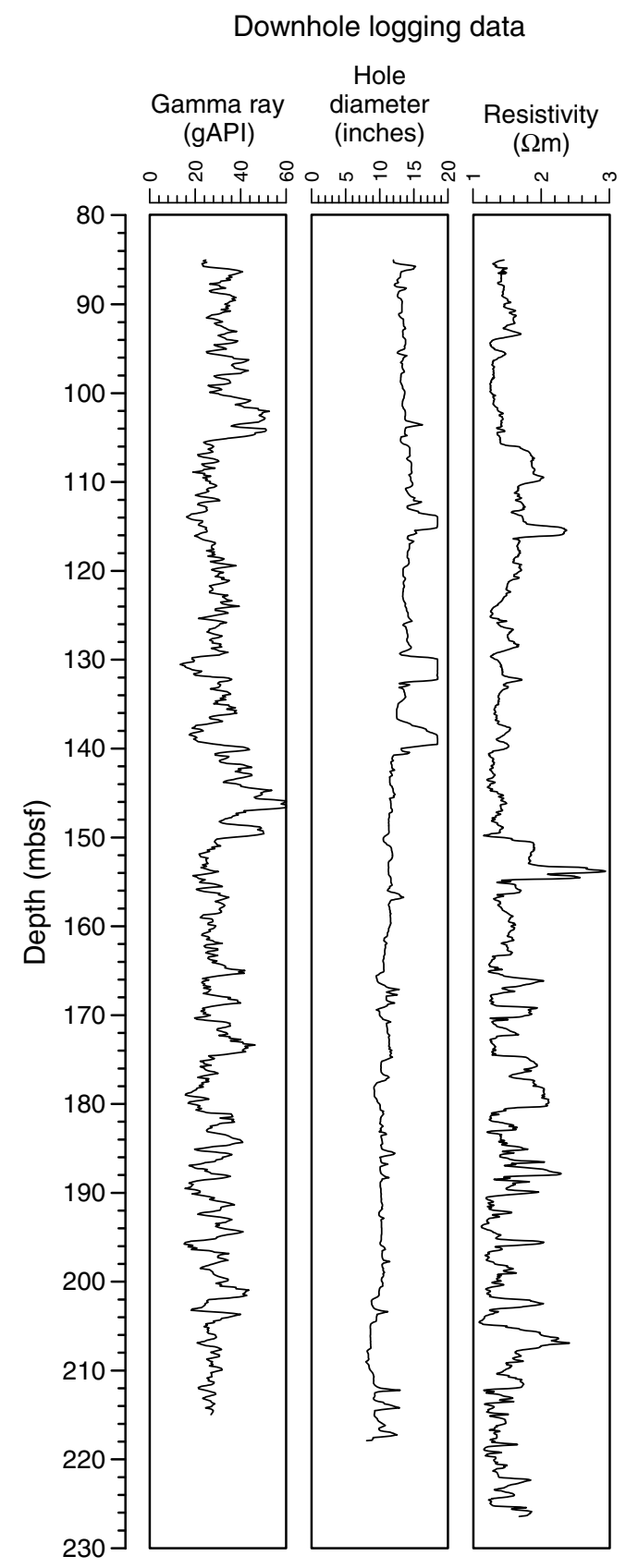



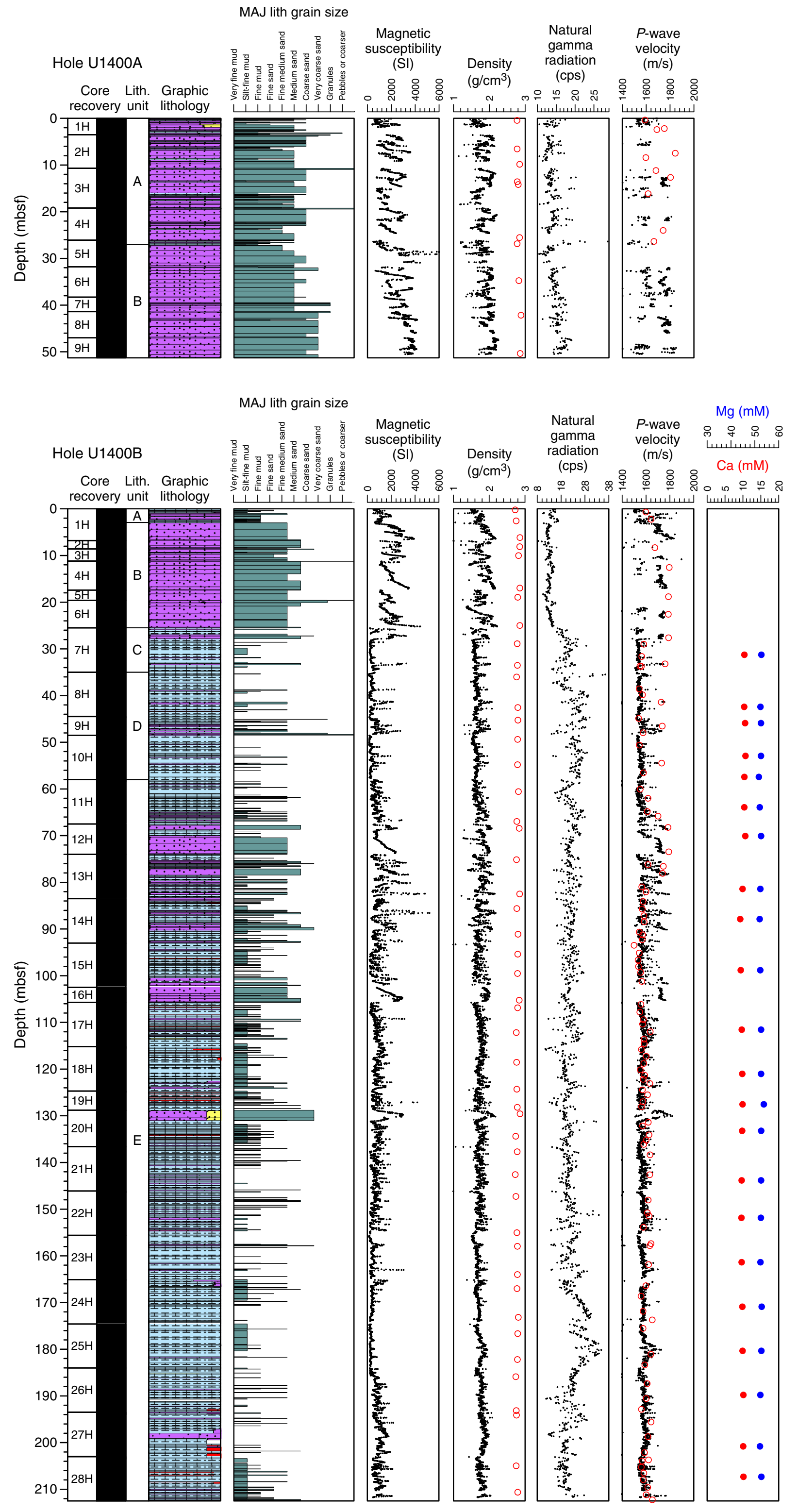
A

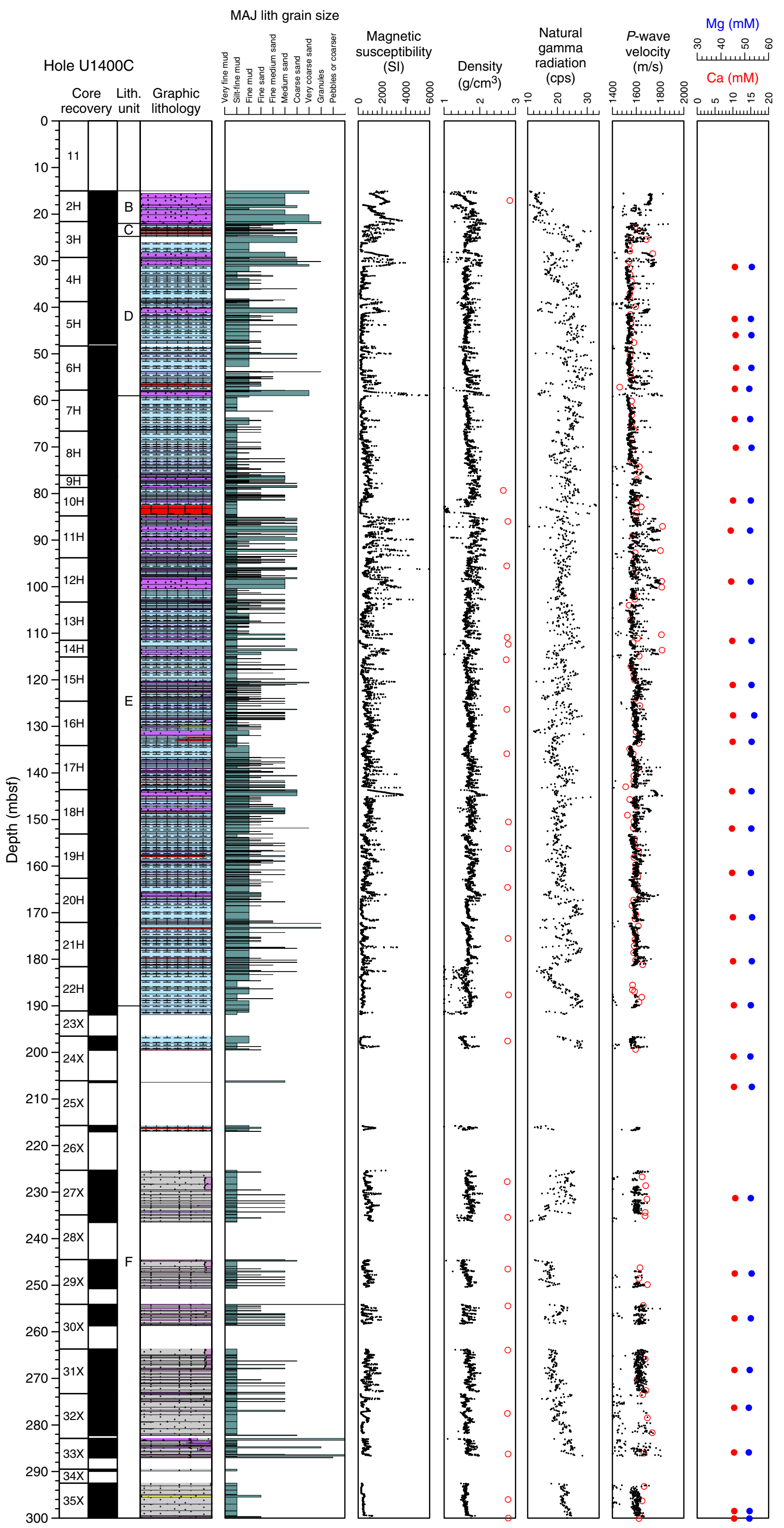


Figure F20 (continued). B. Hole U1400C summary, 300-436 mbsf. MAJ = major, cps = counts per second. See Figure F5B for graphic lithology key.

B

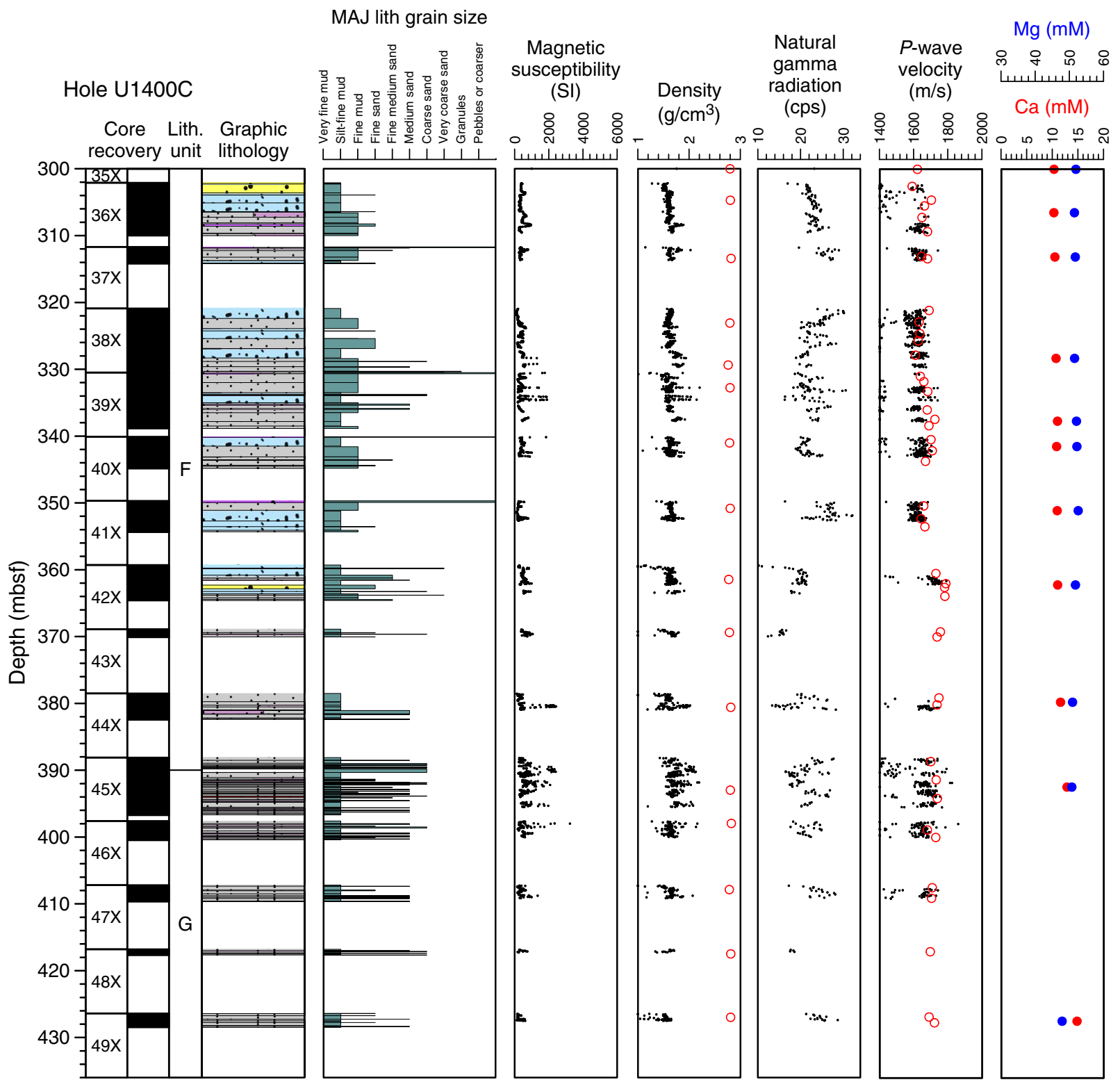


Figure F21. Site U1401 summary. MAJ = major, cps = counts per second. See Figure F5B for graphic lithology key.
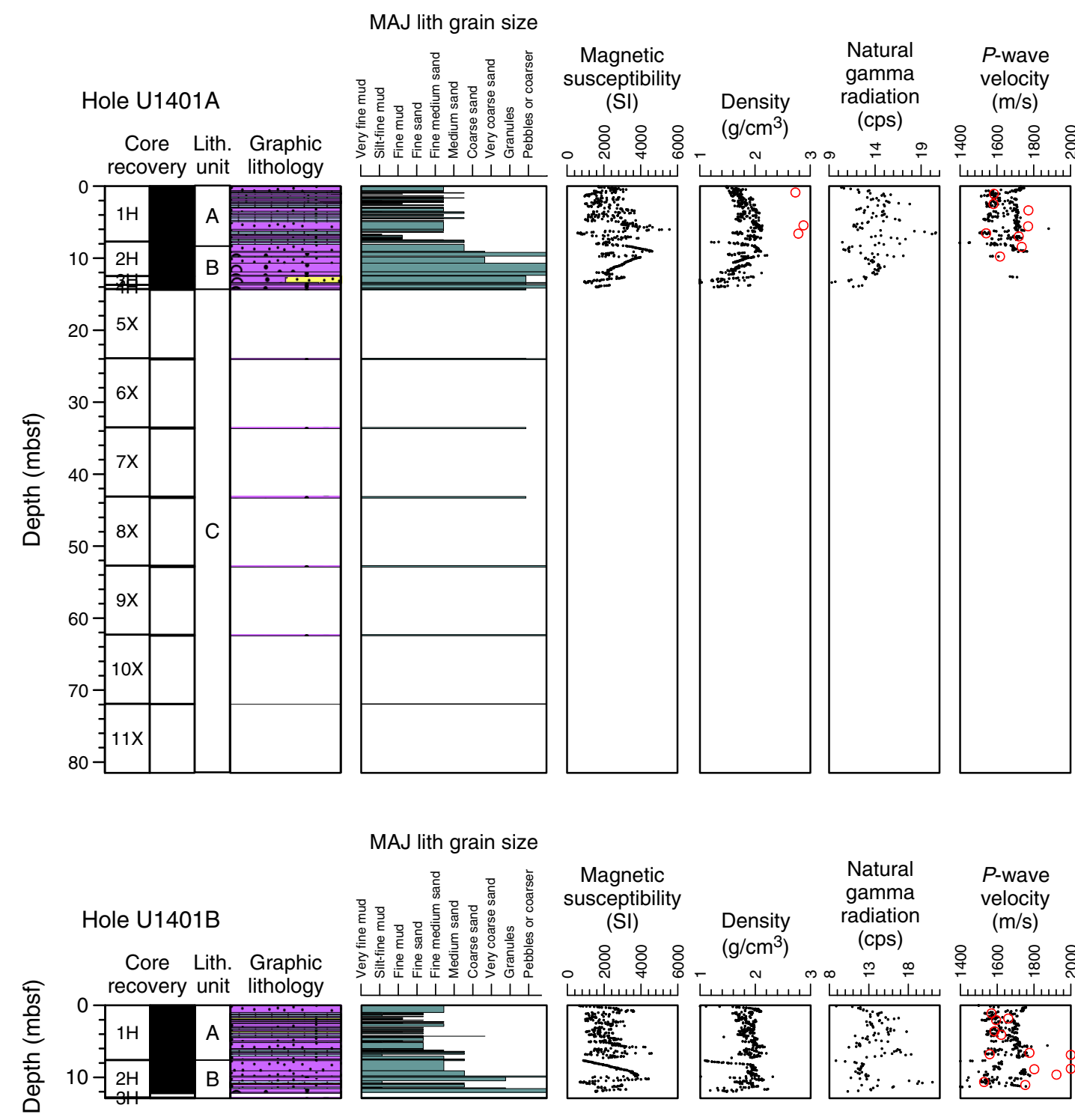

MAJ lith grain size
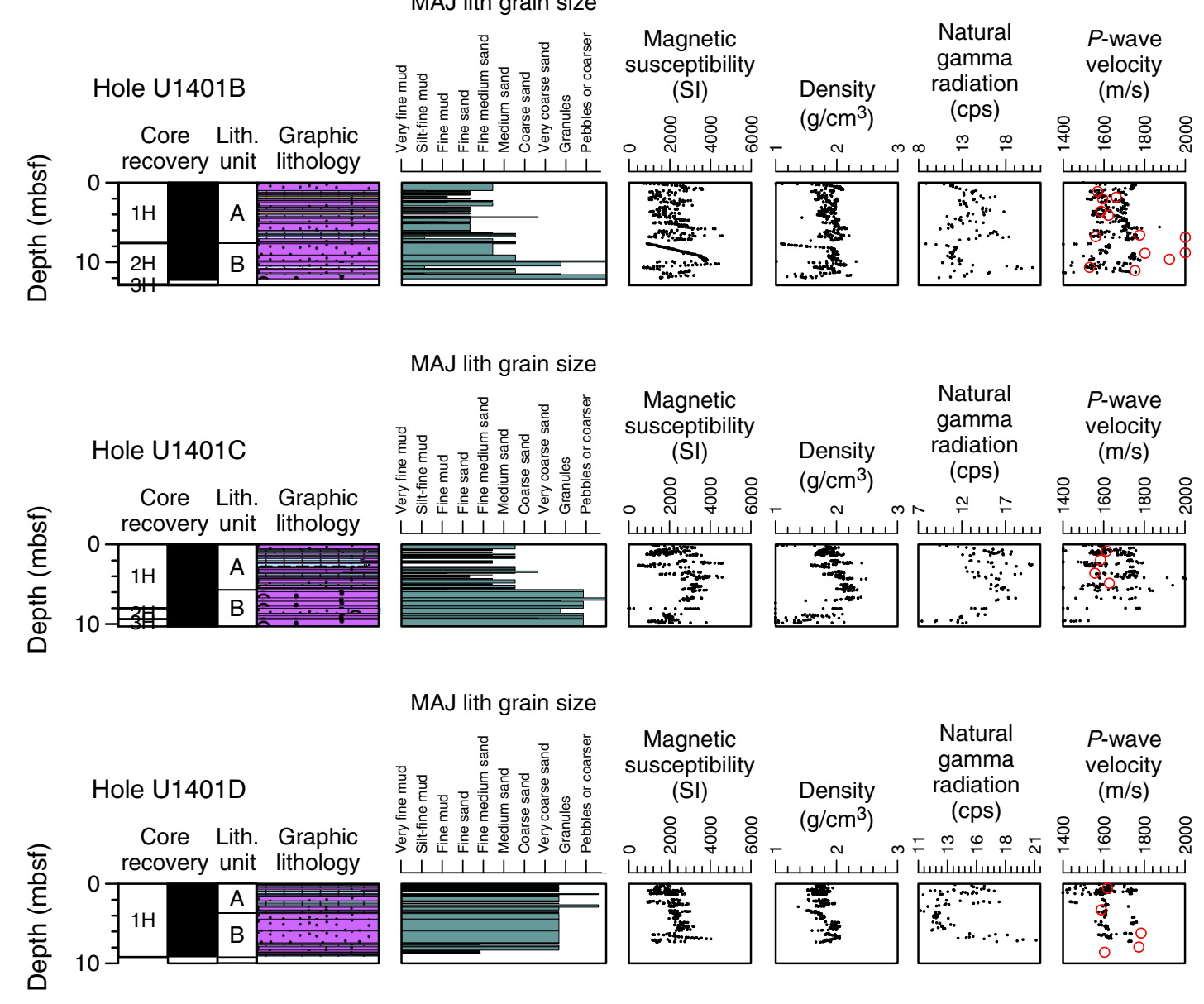
Table T1. Coring summary, Expedition 340.

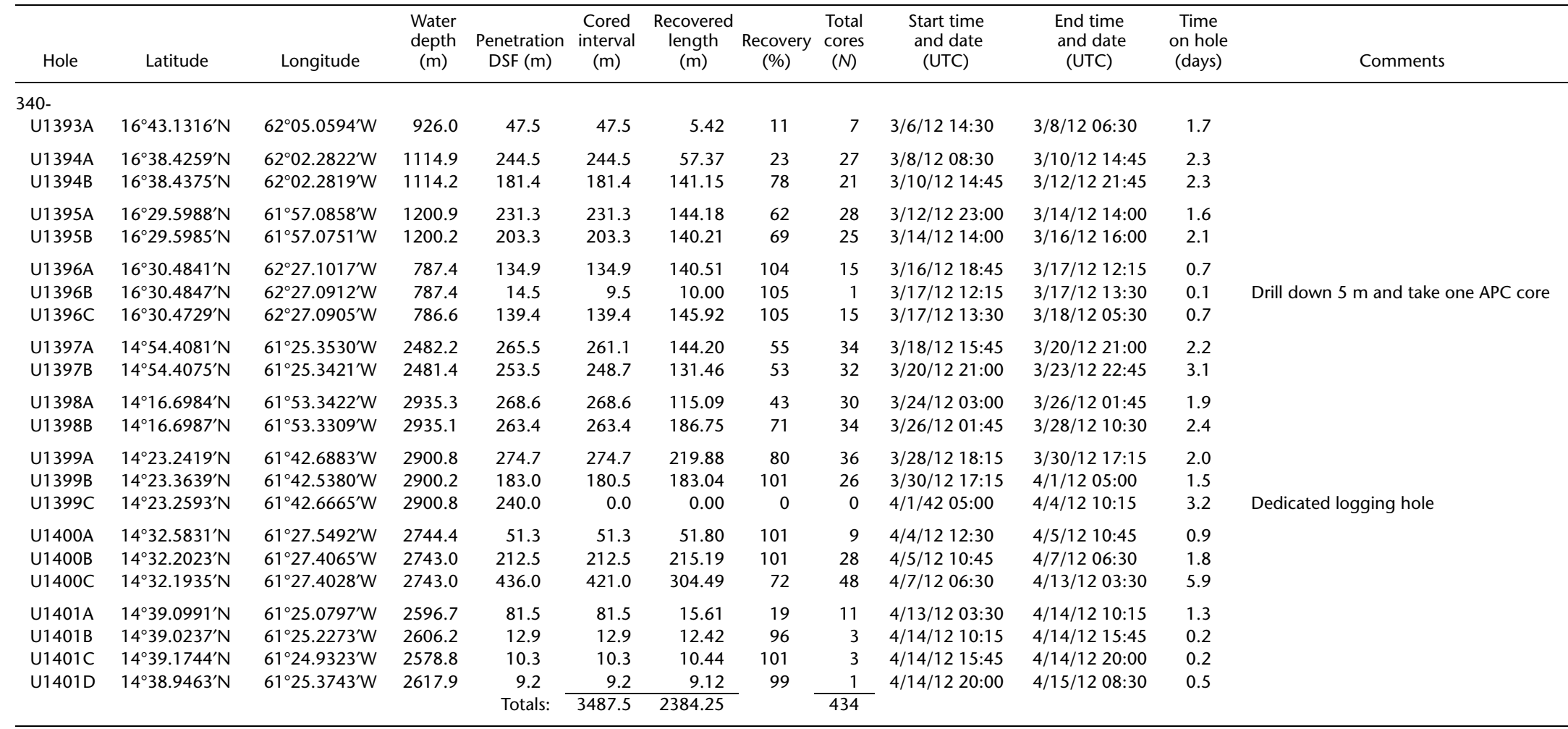

Local ship time was Universal Time Coordinated (UTC) - 4. 